\title{
A COMPARATIVE ANALYSIS OF PUBLIC AND PRIVATE SECTOR SUSTAINABILITY REPORTING OF GOALS AND TARGETS
}

\author{
by \\ Sharmilla Rebecca Raj \\ BES., University of Waterloo, 2013 \\ A thesis \\ presented to Ryerson University \\ in partial fulfillment \\ of the requirements for the degree of \\ Master of Applied Science \\ in the Program of \\ Environmental Applied Science and Management
}

Toronto, Ontario, Canada, 2017

(C) Sharmilla Raj 2017 


\section{$\underline{\text { Author's Declaration }}$}

I hereby declare that I am the sole author of this thesis. This is a true copy of the thesis, including any required final revisions, as accepted by my examiners.

I authorize Ryerson University to lend this thesis to other institutions or individuals for the purpose of scholarly research.

I further authorize Ryerson University to reproduce this thesis by photocopying or by other means, in total or in part, at the request of other institutions or individuals for the purpose of scholarly research.

I understand that my thesis may be made electronically available to the public. 


\section{Abstract \\ A Comparative Analysis of Public and Private Sector Sustainability Reporting of Goals and Targets \\ Sharmilla Raj \\ Master of Applied Science, 2017 \\ Environmental Applied Science and Management \\ Ryerson University}

This thesis aims to investigate the key linkages between public and private sector sustainability reporting of goals and targets. Employing a case study method of Canadian organizations, a content analysis of 109 sustainability reports, along with 22 in-depth interviews were conducted. A review of the literature revealed that extant research in the field of sustainability reporting largely focuses on the private sector, with little attention given to the public sector. Even more so, few studies have explored the linkages between the two sectors. Therefore, this study aims to address an important research gap. Drawing insight from institutional theory, the study provides a comprehensive analysis of the key similarities and differences in public and private sector sustainability reporting goals and targets. Further, it works to outline the advantages, disadvantages, barriers and challenges to linking goals and targets. Finally, it concludes with recommendations on how linking reporting of goals and targets between the public and private sectors should be fostered. 


\section{Acknowledgements}

I would like to express my profound gratitude to Dr. Cory Searcy, my supervisor, for his constant encouragement, guidance and advice. This thesis would not have been possible if it were not for your patient nudges to keep me on track. I would also like to thank my friends and classmates, from whom I learned so much. Finally, I wish to thank my mom, dad and sister for instilling in me the confidence to pursue my interests, and for your unwavering love and support. 


\section{Table of Contents}

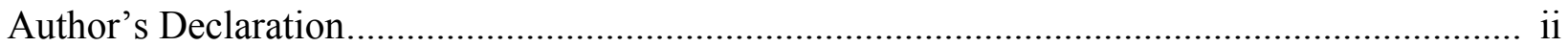

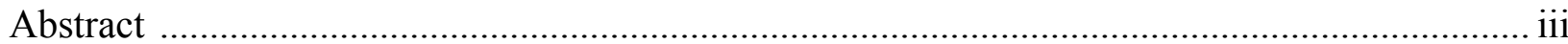

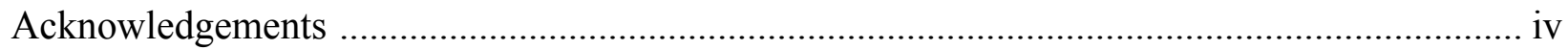

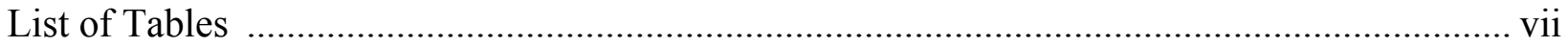

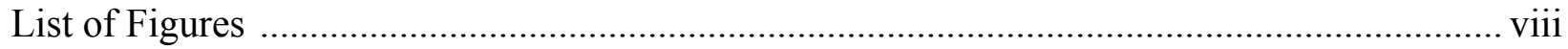

List of Appendices ..................................................................................................... ix

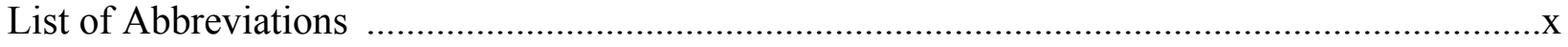

1 Introduction................................................................................................................................. 1

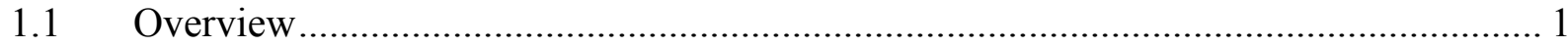

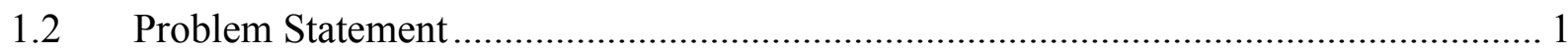

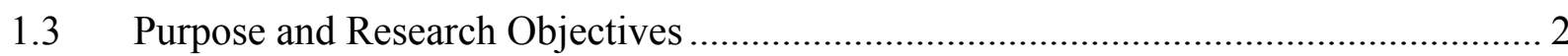

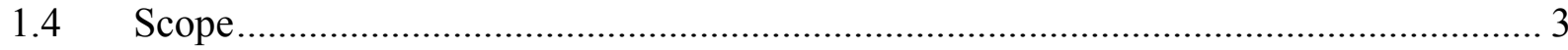

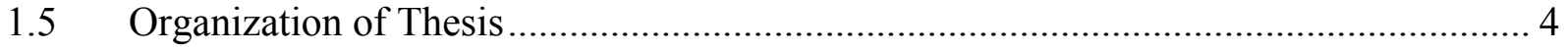

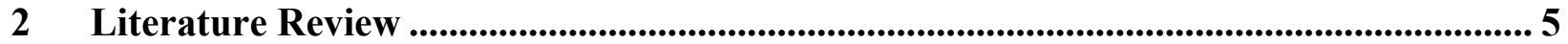

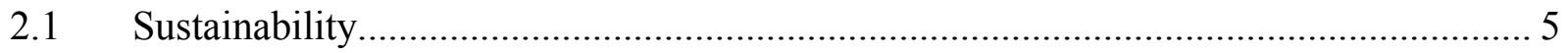

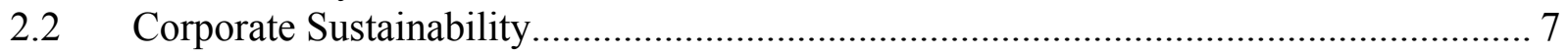

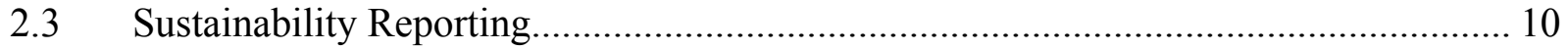

2.3.1 Sustainability Reporting and the GRI .............................................................. 12

2.3.2 Sustainability Reporting and the Private Sector ................................................... 14

2.3.3 Sustainability Reporting and the Public Sector ................................................... 17

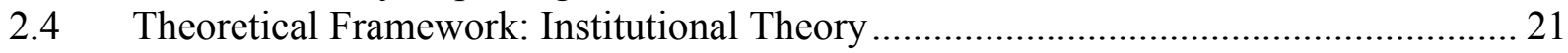

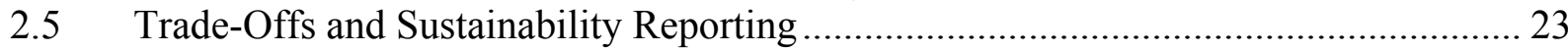

2.6 Current Efforts and the SDGs .................................................................................. 24

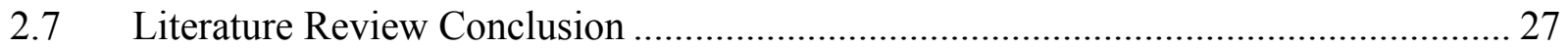

3 Research Questions........................................................................................................ 29

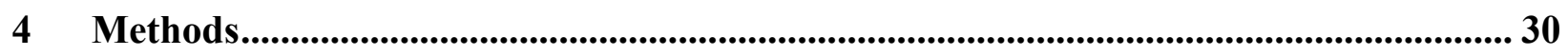

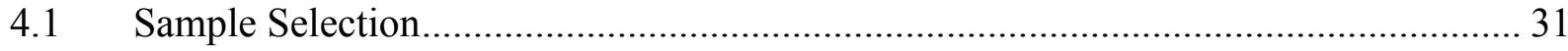

4.1.1 Private Sector Sample Selection ........................................................................ 31

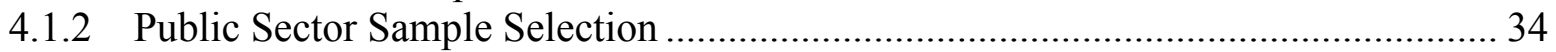

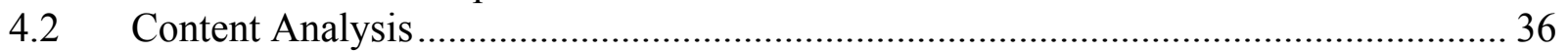

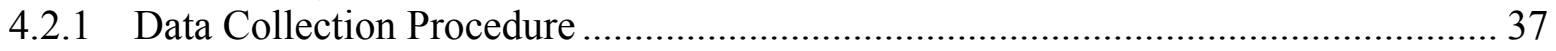

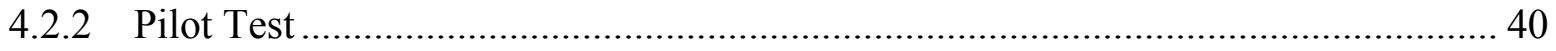

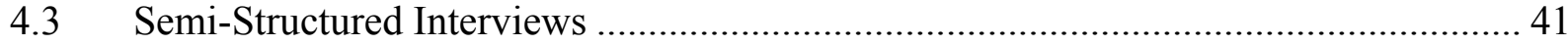

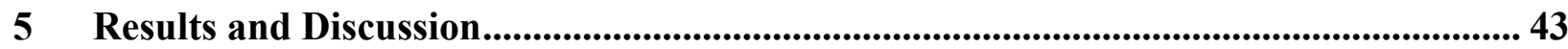

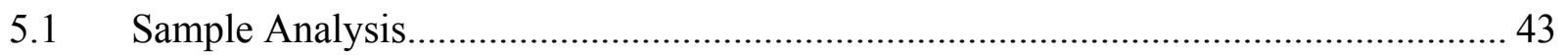

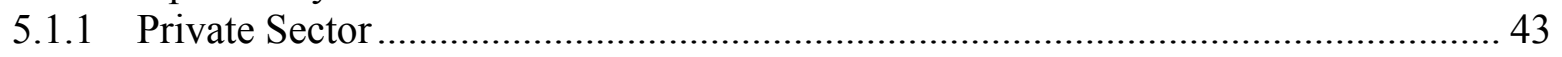

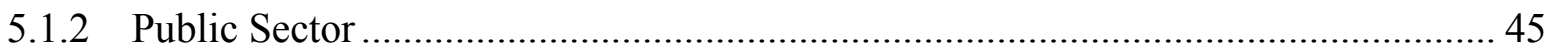

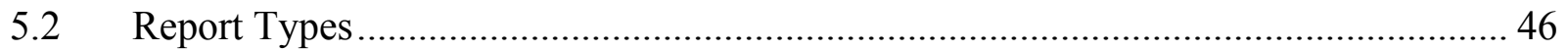

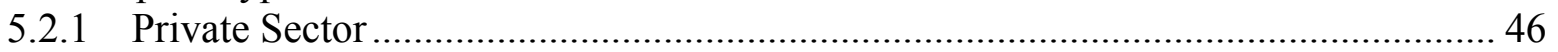

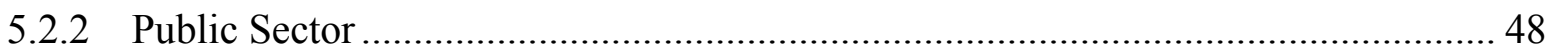

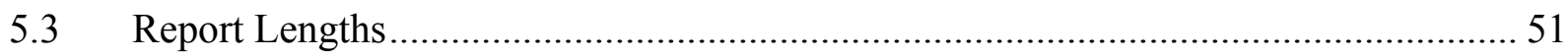




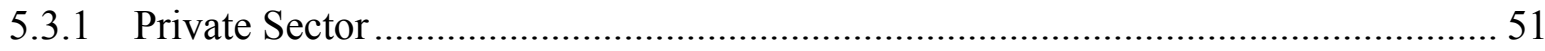

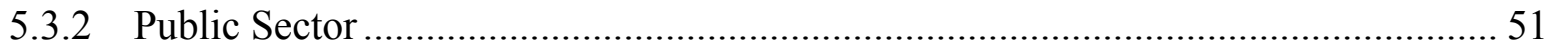

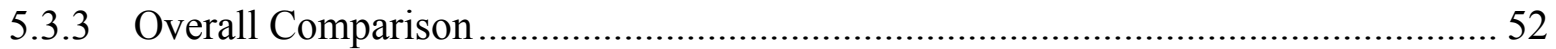

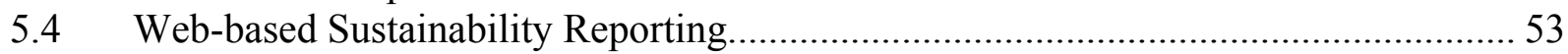

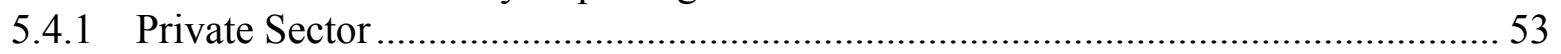

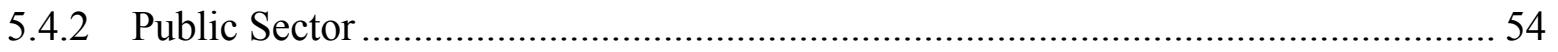

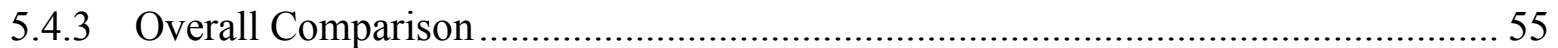

5.5 Sustainability Reporting Frameworks and Standards …………………..................... 55

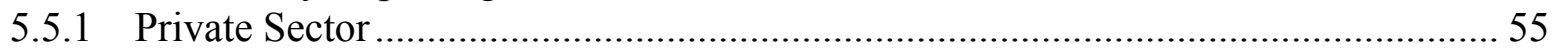

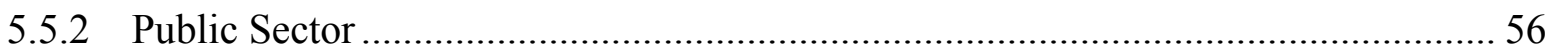

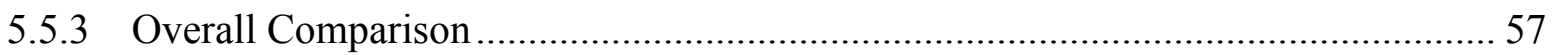

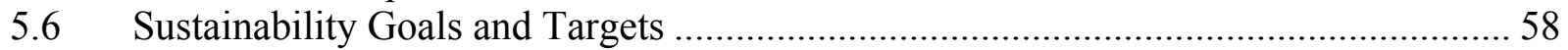

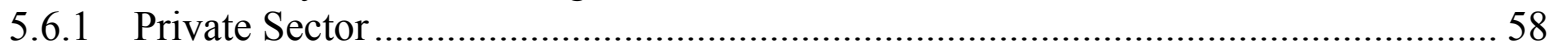

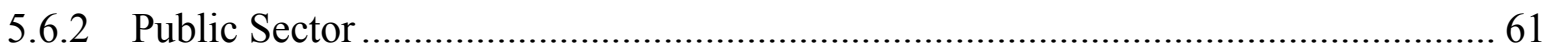

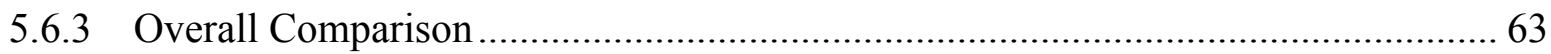

5.7 Public and Private Sector References to Each Other ............................................................ 64

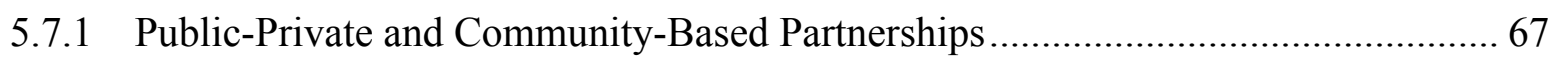

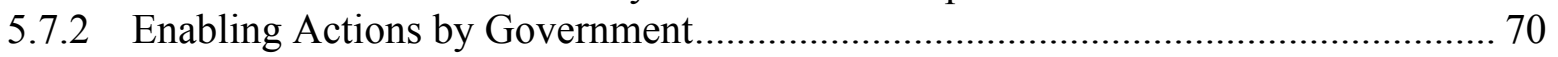

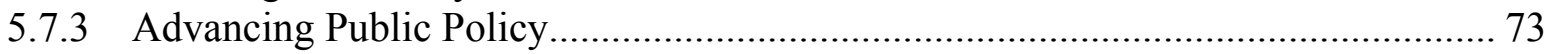

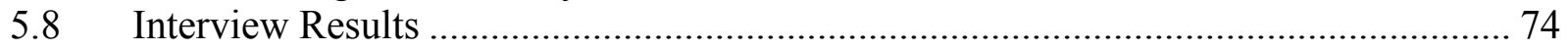

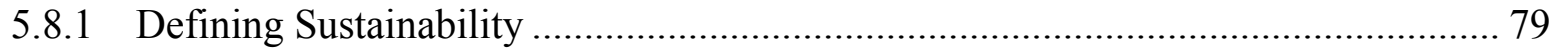

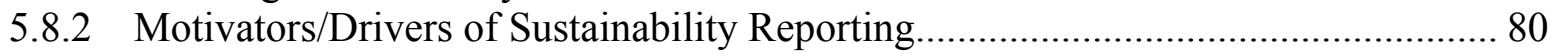

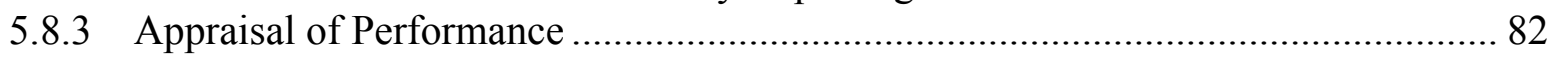

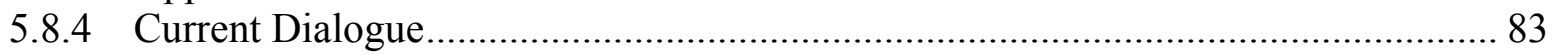

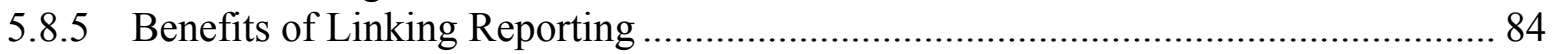

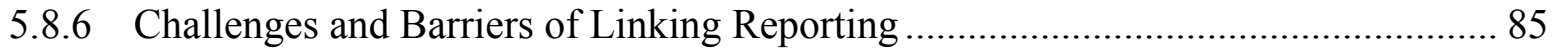

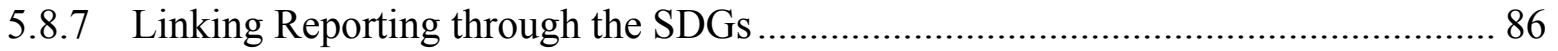

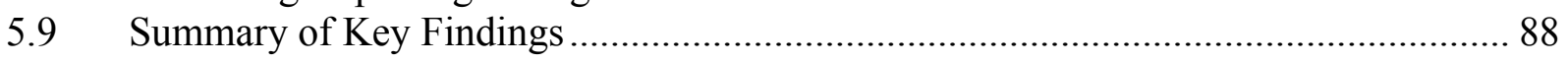

5.9.1 What are the similarities and differences of sustainability reporting between the

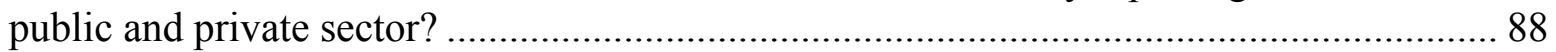

5.9.2 What are the potential benefits and risks of linking reporting between public and

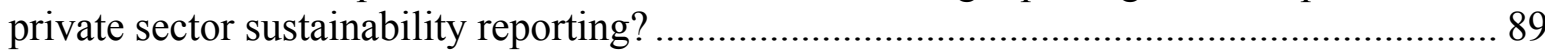

5.9.3 What are barriers and challenges that may inhibit such alignment between private and public sector sustainability reporting from materializing?............................................ 90 5.9.4 What are the trade-offs of linking reporting between public and private sector

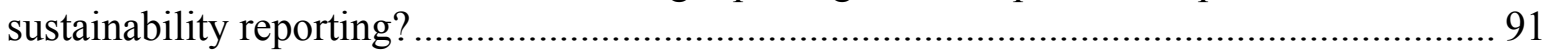

5.9.5 Key Findings and Institutional Theory ………….............................................. 92

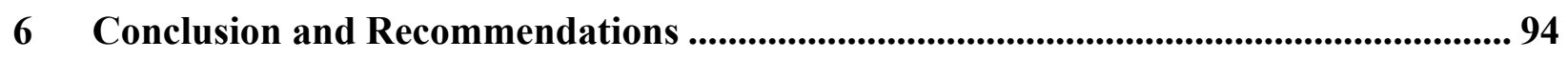

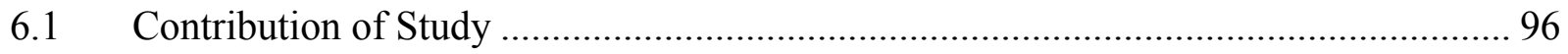

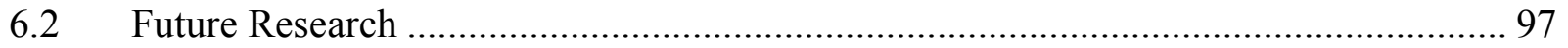

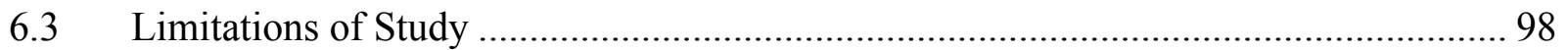

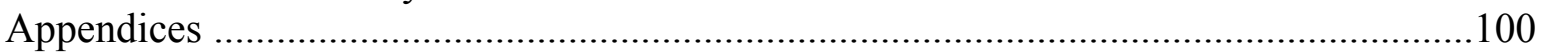

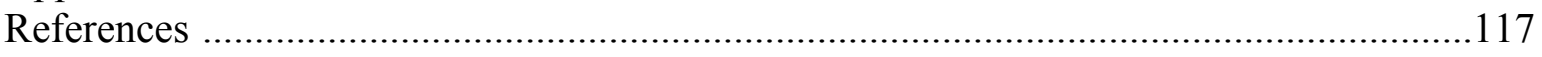




\section{List of Tables}

Table 1: The UN Global Compact Ten Principles............................................................................ 9

Table 2: The United Nations 17 Sustainable Development Goals ................................................ 24

Table 3: Sample of TSX listed Canadian organizations and their industry ................................... 33

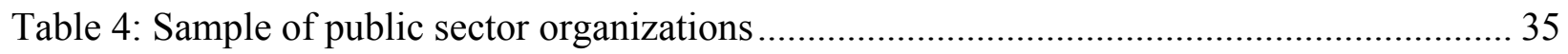

Table 5: Content Analysis key variables, description and rationale for inclusion.......................... 39

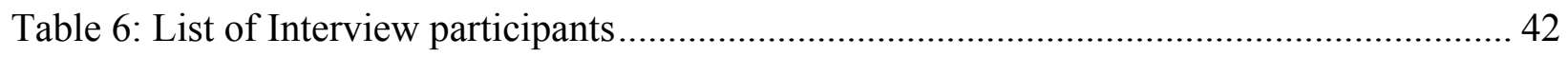

Table 7: Number of private sector organizations per industry ................................................... 44

Table 8: Average length of private sector reports per report type …............................................. 47

Table 9: Average length of public sector reports per report type …………….......................... 49

Table 10: List of reports published by provincial and federal government of Canada.................. 50

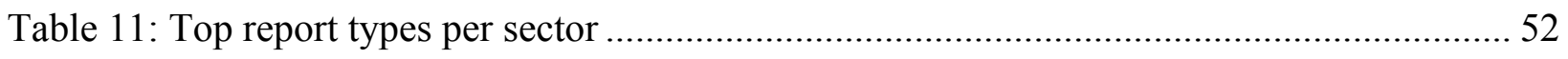

Table 12: List of private sector companies that produce online sustainability report .................. 53

Table 13: Percentage of reporting guidelines/principles referenced by private sector

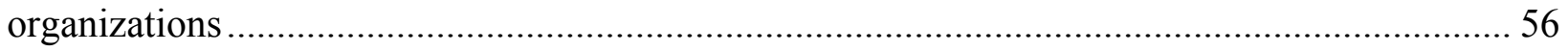

Table 14: Percentage of reporting guidelines/principles referenced by the public sector ............ 57

Table 15: Top 10 Goals/Targets Reported by Private Sector Organizations ................................. 60

Table 16: Top 10 Goals/Targets Reported by Public Sector Organizations .................................. 62

Table 17: List of representative quotes from public and private sector sustainability reports

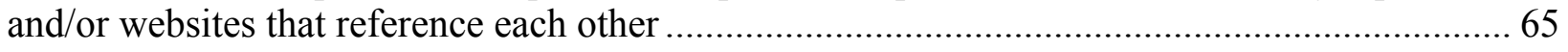

Table 18: List of representative quotes from interviews ......................................................... 75 


\section{$\underline{\text { List of Figures }}$}

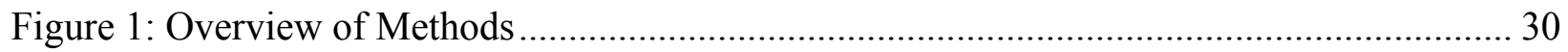

Figure 2: Percentage of private sector companies per industry group................................... 45

Figure 3: Percentage of local governments per Canadian province/territories............................ 46 


\section{List of Appendices}

Appendix A: List of 25 TSX Venture Exchange Organizations removed from original sample

Appendix B: Content Analysis Worksheet (Private Sector)............................................. 103

Appendix C: Content Analysis Worksheet (Public Sector) ................................................... 106

Appendix D: Copy of Consent Form sent to interview participants.................................... 111

Appendix E:Sample Interview Email Invitation............................................................ 115

Appendix F: Copy of Interview Questionnaire Guide ..................................................... 116 


\section{$\underline{\text { List of Abbreviations }}$}

CDP: Carbon Disclosure Project

cCR: Carbonn Climate Registry

CS: Corporate Sustainability

CSR: Corporate Social Responsibility

EMS: Environmental Management Systems

GHG: Greenhouse gas

GRI: Global Reporting Imitative

MDGs: Millennium Development Goals

MNC: Multinational Company

MWM: Measure What Matters

NGO: Nongovernmental Organization

PAS: Public Accountability Statement

SDGs: Sustainable Development Goals

SOE: State of Environment

TBL: Triple Bottom Line

TSX: Toronto Stock Exchange

UNGC: The United Nations Global Compact

WBCSD: World Business Council for Sustainable Development

WCED: World Commission on Environment and Development 


\section{$1 \quad$ Introduction}

\subsection{Overview}

In this thesis, the key linkages between public and private sector sustainability reporting of goals and targets is investigated. A review of the literature reveals that extant work has largely focused on the private sector, with little work exploring the public sector. Even more so, few studies have been carried out on the cohesion between the two. By employing a case study method of Canadian organizations in the public and private sectors, this research study aims to addresses this gap. It outlines the key similarities and differences between the two sectors, drawing insight from institutional theory. Further, it provides a comprehensive analysis on the potential advantages, barriers and challenges associated with linking public and private sector reporting of goals and targets. Finally, a major contribution of the study is that it outlines recommendations for how linking goals and targets should be fostered. In order to address these questions, the study included a content analysis of sustainability reports and websites of 109 organizations. Compounding this, semi-structured interviews with 22 sustainability professionals were conducted.

\subsection{Problem Statement}

In recent years, organizations of all kinds have focused more on demonstrating their commitment to sustainable development (Farneti \& Guthrie, 2009). Growing concerns among members of the public regarding the environmental and social impact of organizations has led to increased focus in areas of sustainability reporting (Alcaraz-Quiles et al., 2014). The term sustainability report can be broadly defined as a "report published by a company or organization on the economic, environmental and social impacts stemming from its daily operations" (GRI, 
2013). When organizations report on sustainability issues, it not only instills trust and transparency with its external stakeholders, such as community, investors and shareholders, but it also enables the organization to more easily identify potential risks and opportunities (GRI, 2013). Both private and public organizations are engaging in sustainability reporting as a means of demonstrating their commitment to protecting the environment, as well as their desire to conduct business in a fair and equitable manner (Lewis, 2008; Williams et al., 2011).

A key problem related to sustainability reporting is the lack of meaningful linkages between public and private sector sustainability reports. Sustainability reporting is done diversely between the sectors with respect to the content and quality of reports published (Farneti \& Guthrie, 2009). This is problematic insofar as it inhibits the adoption of common sustainability goals and inhibits benchmarking (Hahn \& Kuhnen, 2013; Hoekstra et al., 2014). Closer alignment between these sectors could be beneficial insofar as helping organizations identify their contribution to broader public goals. In turn, this could foster more meaningful dialogue, actionable information, and a better understanding of sustainability performance.

Although determining linkages between private and public sector sustainability reporting may yield substantial benefits and contribute to the overall understanding of sustainability reporting, little research has been carried out on this matter (GGKP, 2012; Hoekstra et al., 2014; Van der Esch \& Steurer, 2014). Therefore, it is the aim of this research study to determine the linkages between the public and private sector sustainability reporting, as well as determine how greater alignment may be fostered.

\subsection{Purpose and Research Objectives}

This purpose of this thesis is to investigate the key linkages between public and private sector sustainability reporting in order to determine how closer alignment may be fostered. 
The four research objectives of this thesis are:

1. To identify the similarities and differences of sustainability reporting between the public and private sector

2. To determine the benefits and risks of closer alignment of sustainability reporting between the public and private sector

3. To determine the barriers and challenges that may inhibit the alignment of sustainability reporting between the public and private sector

4. To determine the trade-offs of greater alignment of sustainability reporting between the public and private sector

\subsection{Scope}

This research focused on Canadian private (company) and public (local/regional, provincial/territorial and federal government) sector organizations that published a sustainability report or equivalent. The term "equivalent" refers to other comprehensive reports these organizations commonly use to disclose their sustainability performance. For the private sector, this includes reports such a corporate social responsibility reports, responsibility reports or environmental reports. For the public sector, this includes reports such as sustainability reports/plans, state of environment (SOE) reports, or strategic plans. Annual reports were excluded from this study. Issue-specific reports and/or department-level reports were also excluded. Only reports offered in English were considered for analysis. Organizations such as crown corporations and not-for-profit corporations, such as universities, co-ops, and credit unions, were also excluded from the study. 


\subsection{Organization of Thesis}

This thesis is divided into five remaining chapters. The following chapter presents a review of the literature on sustainability reporting as it pertains to both the public and private sectors. The third chapter outlines the research questions and main objectives guiding the study. The fourth chapter explains the methods employed to address the research questions, along with a detailed description of the data collection procedures and study sample. The fifth chapter presents the results and discussion from the content analysis, followed by the results and discussion from the semi-structured interviews. Lastly, chapter six concludes the thesis with a summary of the findings and recommendations for linking reporting. Chapter six also presents the contributions, recommendations for future research and limitations of the study 


\section{$2 \quad$ Literature Review}

The aim of this chapter is to provide a representation of the relevant literature on sustainability reporting as it pertains to both the public and private sectors. It begins with a history of the conceptual development of sustainability, corporate sustainability and sustainability reporting. The second section provides an overview of sustainability reporting within the public and private sectors independent of one another. It also delineates the most prominent reporting guideline common to both sectors, the Global Reporting Initiative (GRI). The fourth section explains institutional theory as it relates to the study. The fifth section provides an explanation of the trade-offs involved with linking reporting. The sixth section outlines the current efforts made in linking public and private sector sustainability reporting.

\subsection{Sustainability}

Sustainability is a dynamic concept that can be interpreted in various ways. However, the modern use of the term, sustainability, was first popularized by the World Commission on Environment and Development (WCED) in their 1987 UN-sponsored report entitled "Our Common Future"- also referred to as The Brundtland Report. The report defined sustainability as "development that meets the needs of the present without compromising the ability of future generations to meet their own needs" (WCED, 1987, p.8). This definition, while general in nature, provided a global perspective on the relationship between the Earth's ecosystem and human wellbeing. Acceptance of the report by the United Nations General Assembly gave the term political salience worldwide (Chesterman et al., 2016). The report acknowledged the need to consider economic, social and environmental aspects as an integrated and balanced framework for sustainable development (WCED, 1987; Jepson, 2001). Jepson (2001, p. 205) provided a description of this balance, stating "in essence, the emerging sustainability doctrine holds that the 
natural environment can be protected, the economy developed, and equity achieved all at the same time and that the extent to which we are successful in this simultaneous achievement is the extent to which we will achieve sustainability."

Following the groundwork laid by the Brundtland Report, leaders convened at the United Nations Conference on Environment and Development (Earth Summit) in Rio de Janeiro, Brazil. Held in June 1992, The Rio Earth Summit marked one of the most important contributions for the sustainable development movement, resulting in international agreements made on various topics such as climate change, biodiversity and forest management (IISD, 2010). It also resulted in the Rio Declaration on Environment and Development and Agenda 21, requiring countries to develop a national strategy of sustainable development. Ten years later, sustainable development was reaffirmed as an important concept on the global agenda, at the 2002 World Summit on Sustainable Development. Held in Johannesburg, the Summit stressed the importance of participation by all stakeholders, including business, local governments and civil society, in the sustainable development discussion (IISD, 2010).

Sustainable development became a panacea to the world's problems. However, a number of conceptual debates regarding its implementation surfaced. The definition outlined by the WCED was criticized for its failure to provide practical guidance on the construction of policies and practices (Conroy \& Iqbal (2009). Such criticism beckoned an influx of new definitions intentioned to operationalize the concept. However, the subsequent diversity and overlap in terminology created even more confusion (Conroy \& Iqbal, 2009; Johnston et al., 2007). Conroy \& Iqbal (2009) stated that among various fields, and even within the same field, "there is a lack of specificity and unanimity with respect to defining terminology" of sustainability endeavors ( $p$. 110). In other cases, the literature has made note of the uneven representation of environmental 
issues in comparison to social issues, when discussing sustainability (IISD, 2010). Despite such contentions, the practical domain of sustainability, and the literature supporting the field, have grown steadfastly in the past two decades; and this is true as it relates to corporate management and sustainability reporting in both the public and private sectors (London, 2012). The next section will outline sustainability within an organizational setting.

\subsection{Corporate Sustainability}

The application of sustainable development from an organizational perspective is referred to as corporate sustainability (CS) and is perceived as the practice of adopting business strategies and activities that meet the needs of the organization and its stakeholders today, while protecting, sustaining and enhancing the human and natural resources that will be needed in the future (IISD, 1992). This concept of corporate sustainability has a long rooted history, but as Carroll (1979) notes, it was not until the 1960s and 1970s that a significant body of work began to emerge. Although CS has received much attention since then from both business and academia, there is still little definitional consensus on the concept. Closely related concepts, such as "corporate social responsibility (CSR)" are often used interchangeably both among business practitioners and in CS literature (Van Merreqijk, 2003). For instance, the term corporate sustainability is often used synonymously with the term corporate social responsibility (CSR) in recent management literature. However, sometimes the term CSR is used solely for describing social (and societal) aspects of sustainable development. Compounding this, Ebner and Baumgartner (2006) posit that corporate sustainability should be considered the overarching principle, whereby CSR makes up one dimension (social), of the 'triple-bottom line' (TBL) concept. Through an extended review of the literature, Ebner and Baumgartner (2006) attempted to clarify the logic and terminology used 
in CS and CSR communication. The study found that there is still no consensus use of terminology. In order to avoid confusion, this study has chosen to adopt the 'triple-bottom line' definition.

Another distinction to be made is between the terms corporate sustainability and corporate sustainable development. At first glance, the terms seem synonymous, but upon closer inspection, key differences emerge. The key difference is that corporate sustainability is regarded as the desired outcome or end state. In contrast, sustainable development describes the incremental process of continual development towards this end state of 'sustainability'. It is argued that while achieving such an "end-state" is idealistic, it is not possible for any organization to reach. Instead, CS should be characterized as a moving target for organizational development (Van Marreqijk, 2003).

Frequently debated in corporate sustainability literature is the degree to which an organization should engage in corporate responsibility, if at all, and the responsibility it has to the greater society. The Committee for Economic Development (CED) posits that business is a byproduct of public consent, and therefore, organizations must "serve constructively the needs of society - to the satisfaction of society" $(1971$, p. 11). Such an approach forces organizations to fundamentally rethink their role in advancing social objectives, to which they play an integral part. Therefore, the conceptualization of CS gave rise to the accounting framework, "Triple Bottom Line' (TBL) in 1994 by John Elkington. According to Elkington (1998) organizations must take into account three bottom lines when evaluating and communicating its performance: (1) people (social endeavors); (2) planet (environmental impacts); and (3) profit (financial performance).

As Ehrenfeld (2005) stated, organizations are well-equipped with both the intellectual and economic resources to become major players in the sustainability movement. Thereby, an entire international CS industry has emerged in order to direct the implementation of sustainable 
development. Such initiatives comprise of principles, guidelines, standards, reporting frameworks, and rating agencies, as well as CS and CSR consultancies, think tanks, networks and research firms (CGA-Canada, 2005). In particular, the UN Global Compact (UNGC) is one of the most influential drivers of the corporate sustainability movement. The UNGC outlines a set of ten, United Nations approved principles, to guide organizations on their sustainability strategy and actions in areas of human rights, labor, environmental, and anti-corruption (Blanco, et al., 2013). Furthermore, it encourages organizations worldwide to report on their performance in those important areas. To date, 9,000 organizations in 140 different countries have joined the UNGC, evidencing the growing commitment to corporate sustainability (UNGC, 2016). Table 1 provides a list of the ten UNGC principles.

\section{Table 1: The UN Global Compact Ten Principles}

\section{Principles of the UN Global Compact}

\begin{tabular}{|c|c|}
\hline Human Rights & $\begin{array}{l}\text { Principle 1: Businesses should support and respect the protection of } \\
\text { internationally proclaimed human rights, and } \\
\text { Principle 2: make sure they are not complicit in human rights abuses }\end{array}$ \\
\hline Labour Standards & $\begin{array}{l}\text { Principle 3: Businesses should uphold the freedom of association and } \\
\text { the effective recognition of the rights to collective bargaining; } \\
\text { Principle 4: the elimination of all forms of forced and compulsory } \\
\text { labour } \\
\text { Principle 5: the effective abolition of child labour } \\
\text { Principle 6: the elimination of discrimination in respect of employment } \\
\text { and occupation. }\end{array}$ \\
\hline Environment & $\begin{array}{l}\text { Principle } 7 \text { : Businesses should support a precautionary approach to } \\
\text { environmental } \\
\text { challenges; } \\
\text { Principle } 8 \text { : undertake initiatives to promote greater environmental } \\
\text { responsibility; } \\
\text { Principle } 9 \text { : encourage the development and diffusion of } \\
\text { environmentally friendly } \\
\text { technologies }\end{array}$ \\
\hline Anti-corruption & $\begin{array}{l}\text { Principle 10: Businesses should work against corruption in all its } \\
\text { forms, including extortion and bribery }\end{array}$ \\
\hline
\end{tabular}

Source: www.unglobalcompact.org 
Alongside this commitment, sustainability reporting has become an integral part of the CS practice, as it is used by entities to "measure, disclose, and be accountable to internal and external stakeholders" and therefore is a critical component for organizations advancing toward corporate sustainability (Van Wensen et al., 2011). The next section will discuss sustainability reporting in greater detail.

\subsection{Sustainability Reporting}

A review of the available literature reveals a number of important issues related to sustainability reporting and the different approaches to this practice within the private and public sectors. The GRI (2013, p. 3) defines sustainability reporting as a practice to "help organizations set goals, measure performance, and manage change in order to make their operations more sustainable". A sustainability report, as defined by Daub (2007, p. 76) must "contain quantitative and qualitative information on the extent to which the organization has managed to improve its economic, environmental and social effectiveness and efficiency in the reporting period and integrate these aspects in a sustainability management system." A sustainability report is commonly offered as a hard-copy, in PDF-format, or in an online version via the organization's website (Van Wensen, et al., 2011). Both private and public organizations are engaging in sustainability reporting as a means of demonstrating their commitment to protecting the environment, as well as their desire to conduct business in a fair and equitable manner (Lewis, 2008; Williams, et al., 2011).

The first wave of sustainability reports began in the late 1970 s, with approximately $90 \%$ of Fortune 500 companies including some form of social information in their annual reports (Mathews, 1997). However, as the 1980s emerged, and concerns over environmental issues, such as acid rain, ozone layer depletion and the release of environmental contaminants such as PCBs, 
were at the forefront, companies began to shift their focus from social reports to environmental reports. This trend only intensified during the 1990s, especially within North America and Europe (Mathews, 1997). In the United States, the "right to know" legislation was introduced as an effort to make emissions data available to the public. This legislation was seen as an extremely important step forward and also one of the major initiatives to compel organizations to report on sustainability issues (CGA-Canada, 2005). From a public sector perspective, and while sustainability reporting in the private sector was still in its infancy, local authorities and government agencies were seen as the major change drivers of sustainable development. In response to Chapter 28 of the Agenda 21 document (Keating, 1993), many local authorities produced reports aimed at tackling local sustainability issues. In recent years, reporting requirements for sustainability performance of organizations within both private and public sectors have increased in many countries around the world (Hargroves \& Smith, 2005). According to a study done by KPMG in 2013, there has been a dramatic increase in sustainability reporting worldwide since 2011 with the highest growth in countries such as Australia, Singapore, Taiwan and China.

Despite the fact that public and private organizations are engaging more in sustainability reporting, often, there are significant differences in terms of the metrics analyzed, or the definitions used by the authors of this report (Daub, 2007). One definition of sustainability holds that the concept itself refers to "a state wherein an organization's activities lead to a good standard of life for all, without threatening the environment or ecological systems that facilitate our survival" (Lewis, 2008 p. 329). Over time, sustainability reporting emerged as a way for organizations to provide improved reporting related to the environmental and social impacts stemming from their operations (Farneti \& Guthrie, 2009). Despite the definition noted above, there is no single, unified 
concept of sustainability used to guide sustainability reporting (Farneti \& Guthrie, 2009). Furthermore, there is little consensus on the information required and the structure of sustainability reports produced by organizations (Davis and Searcy, 2010). This lack of consistency between sustainability reporting practices in different organizations represents a considerable issue worldwide.

\subsubsection{Sustainability Reporting and the GRI}

Indeed, it is noted that as sustainability reporting increases in popularity, there has been a corresponding development of guidelines, standards and principles that help organizations to produce sustainability and other types of reports (White, 2009) (e.g. ISO Environmental Management Systems [ISO 14001 EMS]; Carbon Disclosure Project [CDP]; Global Reporting Initiative $[\mathrm{GRI}]$ ). Among these, the most widely recognized is the Global Reporting Initiative (GRI) Sustainability Reporting Guidelines (Adams, et al., 2014; Brown, et al., 2009).

The GRI was founded in Boston, USA in 1997 out of the Coalition for Environmentally Responsible Economies (CERES) and the United Nations Environment Programme (UNEP). It prides itself on the multi-stakeholder approach it has taken, and rightfully so, with a broad coalition of actors from business, labor, civil society and financial markets, as well as regulators and government agencies from around the globe (Adams et al., 2014). In its role as an international advisory body, the GRI has advanced some specific guidelines for sustainability reporting by organizations (Farneti \& Guthrie, 2009). These guidelines include both the types of information to include, as well as general principles for defining the content and quality of the report (GRI, 2013). Today, the GRI is seen as the leading authority on sustainability reporting, and its guidelines are viewed as the standard for both private and public sector organizations engaging in sustainability reporting (Hahn \& Kuhnen, 2013). 
In 2000, the GRI published its first set of guidelines $(\mathrm{G} 1,2000)$ which contained reporting principles and specific content indicators to represent the organizations economic, social, and environmental performance, regardless of their size, sector or location. The G4 guidelines are the latest version of the GRI guidelines, released in May 2013. The main objective of the guidelines is to encourage reporters to examine their entire value chain, and disclose information that is most material to the organization (Hanks \& Baxter, 2014). In defining materiality, the GRI suggests that organizations should report on 'aspects' that "reflect the organization's significant economic, environmental, or social impacts, or substantially influence the assessments and decisions of stakeholders" (GRI, 2013). The organization must also disclose why the selected issue is material, and how they plan to address it. The new guidelines have also advanced a number of different indicators from its predecessors, and these reflect a heavier focus on value chain reporting, particularly with assessing supplier responsibility on environmental, human rights, labor relations and societal issues (Hanks \& Baxter, 2014).

Statistics suggest that the GRI has been relatively successful in accomplishing its mandate; between 1998 and 2005, the percentage of the top 250 global organizations engaged in sustainability reporting increased from 35 percent to 70 percent (Hargroves \& Smith, 2005). Recent studies coincide with this; in the year 2010 alone, the number of sustainability reports registered on the GRI Reports List increased by 22 percent (GR1, 2011). Furthermore, according to a survey conduced by KPMG in 2013, 82 percent of the 250 largest companies relied on the GRI guidelines (KMPG, 2013).

Despite the fact that the GRI is viewed as the "de-facto" standard, it is noted that a number of discrepancies continue to exist between the sustainability reporting practices of different organizations around the world (Hahn \& Kuhnen, 2013). Indeed, these reports can vary 
significantly in terms of the content they include, as well as the quality of information included (Hahn \& Kuhnen, 2013). A study conducted by Roca and Searcy (2012) outlined the indicators disclosed by 94 Canadian companies. The study revealed that despite half of the sample following the GRI guidelines, environmental and social indicators disclosed in reports varied among the different industries. Such information helps to make clear the notion that in spite of a global standard-bearer for sustainability reporting, acceptance of a global standard remains elusive.

\subsubsection{Sustainability Reporting and the Private Sector}

For organizations in the private sector, sustainability reporting is posited as being able to increase transparency, strengthen the company's reputation, promote brand value, show competitiveness with other firms (White, 2009), facilitate benchmarking and comparisons against competitors, motivate employees, and more (Hahn \& Kuhnen, 2013). Particularly relevant to listed companies, sustainability reporting can help secure high rating scores and benchmarks can attract investors (INTOSAI, 2013). Indeed, the private sector has embraced sustainability reporting due to its sheer relevance; the literature notes that for private organizations, issues related to sustainability are directly linked to company financial performance (Lewis, 2008). Adams (2002) assert that private sector organizations primarily engage in sustainability reporting merely to enhance their public image, while Milne et al. (2009) state that they report for purely economic gains.

From a regulatory standpoint, the introduction of mandatory sustainability reporting, or the anticipation of such regulations on company activities, may lead organizations to report (McKinsey \& Company, 2011). Unsurprisingly, more companies produce sustainability reports when subjected to government regulations. A recent study by Ioannou and Serafeim (2014), analyzed how the introduction of mandatory sustainability reporting altered corporate disclosure 
practices in China, Denmark, Malaysia and South Africa. The study found that corporations increased their disclosure of sustainability performance following the introduction of mandatory reporting guidelines. It also found that organizations were more likely to seek out third-party assurance, and adopt a reporting framework. Following the introduction of the Danish Financial Statements Act, which requires larger companies to produce sustainability reports, the number of companies producing reports grew from $50 \%$ to $95 \%$ (Hoekstra et al., 2014).

Other research has produced findings which demonstrate that private sector organizations may be more likely to engage in meaningful sustainability reporting practices because it is in their best interest to do so. Research comparing the sustainability reporting practices of nongovernmental organizations (NGOs) and multi-national corporations (MNCs) shows that MNCs typically outscore NGOs across a number of dimensions related to sustainability reporting (Crespy \& Miller, 2011). Moreover, research shows that private sector organizations have dramatically increased their sustainability reporting in recent years; between 2001 and 2008, the total percentage of MNCs engaged in sustainability reporting increased from 35 percent to 64 percent (Crespy \& Miller, 2011). Other research shows that businesses can benefit from sustainability reporting through the increased transparency such reporting creates (White, 2009). Other research shows that sustainability reporting by companies in the private sector leads to improvements in financial and economic performance (Orlitzky, Siegel, \& Waldman, 2011). The process of sustainability reporting is said to help organizations identify internal and external opportunities and risks. For instance, it may help to identify areas where resource efficiency may be improved, or eco-innovation may be introduced (McKinsey \& Company, 2011). As stated by Cowen et al. (2010, p. 525) "for protecting the future of the global environment, sustainability is important, but 
as a business driver it can also be viewed as an investment in the future, and a pathway to innovation and creative thinking”.

The GRI has also helped to spur sustainability reporting among private sector organizations (Barkemeyer et al., 2014). However, research shows that despite an increase in sustainability reporting, there are questions regarding the quality of content produced in these reports, and whether or not many sustainability reports authored by private sector companies are useful for meaningfully assessing a company's sustainability overall (Barkemeyer et al., 2014). Cooper and Owen, (2007) questioned whether sustainability reporting among companies in the private sector is a meaningful form of disclosure at all (Cooper \& Owen, 2007). Researchers have argued that the types of information disclosed in sustainability reports by private companies are generally not actionable, particularly from the perspectives of the stakeholders affected (Cooper \& Owen, 2007). Such information suggests that even when private sector companies engage in sustainability reporting and disclose information related to their sustainability practices, the information they disclose does not create greater opportunities for the involvement of key stakeholders affected by operations. Furthermore, the literature notes that although there has been an increase in private sector organizations utilizing reporting standards, the reports remain inconsistent. (Behnam and MacLean, 2011; Dumay et al., 2010). This may be linked to the voluntary nature of these standards, leaving organizations with the autonomy to "cherry-pick" information that is favorable to them (Clapp, 2005; Dumay et al., 2010). Private sector companies have also indicated that their sustainability reporting practices have not been influenced by public policy or government, and that many corporations are not looking for additional guidance on sustainability reporting from the public sector (Beare et al., 2014). Furthering this point of contention, the GRI provides little guidance on how to strengthen the relationship between corporate sustainability reporting and 
public policy (Beare et al., 2014). The private sector's lack of interest in reporting practices in the public sector suggests significant differences in sustainability reporting between public and private sector organizations.

\subsubsection{Sustainability Reporting and the Public Sector}

Organizations in the public sector are viewing the reporting and publication of information related to sustainability practices as increasingly important (Alcaraz-Quiles et al., 2014). Prior research on sustainability reporting focused exclusively on private sector disclosure practices, leaving until recently, relatively little work on public sector disclosure practices. It is argued that not only is it important for the public sector to engage in sustainability reporting due to the size of their involvement in national economies, but public organizations traditionally deal with a range of activities and practices that are strongly linked to the concept of sustainability (Adams et al., 2014). Ball and Gubnic (2007) reinforced this claim by urging the proliferation of research on sustainability reporting accounting and accountability in public sector organizations, whose core tasks are intrinsically correlated with social welfare and justice. The responsibilities of the public sector range from the management of essential mineral resources to providing critical public services, such as transportation. As a result, they comprise one of the largest sectors in any country, and their impacts are far-reaching (Ball and Gubnic, 2007). As the Global Reporting Initiative (GRI) argues "Public agencies have a civic responsibility to properly manage public goods, resources and/or facilities in a way that supports sustainable development objectives and promotes the public interest. Public agencies are expected to lead by example in reporting publicly and transparently on their activities to promote sustainability" (GRI, 2005). Even more so, unlike companies, public sector organizations are responsible for a specific geographical region. Therefore, they can provide important information on the performance of ecosystems and regions 
(Ball and Bebbington, 2008). With that said, public sector organizations not only have the responsibility, but also the opportunity, to contribute greatly to sustainability performance disclosure.

Despite the public sector's important role in advancing the sustainability agenda, Ball and Grubnic (2007) assert that they receive far less public attention and scrutiny than the private sector on their sustainability disclosure practices. Moreover, the literature notes that public sector organizations are unlikely to view sustainability itself as a fundamentally important area of business (Lewis, 2008). Reaffirming this notion, a recent study by London (2012) revealed that representatives from public sector organizations did not feel as though their actions were strongly associated with sustainability goals. Although there is relatively little research on the sustainability reporting practices of public sector organizations, some research has demonstrated that sustainability reporting plays an important role in the nature of relations between a government body and the citizenry (Alcaraz-Quiles et al., 2014).

Evidence suggests that more and more public sector organizations are beginning to engage in sustainability reporting (Williams et al., 2011). Research from Australia shows that half of respondents in the public sector were engaged in sustainability reporting, with data collection on at least one measure of sustainability being included in reports (Williams, Wilmshurst, \& Clift, 2011). Moreover, this research also found that among the respondents who were not currently engaged in sustainability reporting, approximately 40 percent indicated their intention to start sustainability reporting at some point in the near future (Williams et al., 2011). These findings mirror those obtained in other studies which show that sustainability reporting, while still in its infancy, is growing in popularity among public sector organizations (Guthrie \& Farneti, 2008). 
At the same time, it is noted that while many governments at different levels deal with activities related to sustainability, many public sector organizations are lacking in any kind of approach to foster sustainability in operations (Lewis, 2008). Consistent with this notion, Adams et al., (2014) state that public sector information tends to be "scattered across a number of documents; to focus on policies rather than performance information; to be inconsistently presented across; and, to focus on measurement of external conditions (as in "state of the environment" reports) rather than public agency performance and impacts" (Adams et al., 2014). Lewis (2008) states that there is a lack of availability of tools and resources for the public sector to effectively measure and report on sustainability initiatives and results. Despite efforts to establish such tools and programs, there are currently no widely adopted and consistent benchmarking models to guide the public sector in this endeavor. This contributes to a lack of broad-based consensus that could otherwise allow for national best practice models to be established (INTOSIA, 2013). In this respect, Dumay et al., (2010) stressed that more research is currently needed on how the management of sustainability and accountability can be applied to ensure that public organizations make a greater contribution to sustainable development.

In order to address some of these issues, the GRI published Sector Supplements for Public Agencies (SSPA): Pilot Version 1.0, in March 2005 (GRI, 2005), later revised in 2010 (GRI, 2010). Many researchers, however, have criticized the GRI guidelines (and the SSPA) for being too generic, difficult to apply, and not very useful to public sector organizations (Farneti et al., 2009; Lodhia et al., 2012). Tort (2010) conducted a study on the application of the GRI SSPA in public sector reports. The study found that the indicators disclosed in reports varied significantly. This was similar to the findings of an Australian study as reported in Dumay et al., (2010). Guthrie and Farneti (2008) added that this information was particularly weak in human rights and society 
categories. Adams et al., (2014) conducted a similar analysis, finding sustainability performance measures the strongest in employee diversity and economic activity, with environmental and social justice issues given least attention in public sector reports. Both studies concluded that the primary reason for such poor reporting among public sector organizations was directly linked to the inherently non-competitive environment in which they operate, and that reports were generated merely to satisfy internal stakeholders (Guthrie and Farneti, 2008). Adams et al., (2014) added that public sector organizations were unlikely to increase sustainability reporting unless it became mandatory, or if the non-competitive nature of their operations changed, "even if this is just tying resources competitively to performance measurement across all sustainability indicators (Adams et al., (2014)".

The most commonly produced report types disclosed by the public sector can be divided into three main categories: State of environment reports (SOE) that focus on the environmental conditions of a specific geographical area (country, state, region, city or municipality), annual reports that focus on the overall performance of an organization, and policy or strategy reports such as an environmental plan or sustainable strategy report (GRI, 2012). It is less common, however, for public sector organizations to produce "company-style" sustainability reports (INTOSAI, 2013). Nevertheless, the public sector's experience in, for example, producing SOE Reports, is arguably similar to that of the private sector's experience in producing corporate sustainability reports (INTOSAI, 2013). London (2012) stresses that irrespective of sector, substantial commonalities exist among most organizations pursuing sustainability endeavors (London, 2012, p. 140). Thereby, such a comparison between private and public sector sustainability reporting is a worthy undertaking. 
Research on why public sector organizations choose to engage in sustainability reporting has demonstrated that sustainability reporting typically occurs to inform and satisfy stakeholders within the organization itself (Farneti \& Guthrie, 2009). Public organizations typically function in relatively non-competitive environments. As a result, the need to gain external legitimacy from voluntary sustainability reporting is less robust than those found in the private sector (Brown et al., 2009b). Instead, internal pressure, such as the coercive force of legislation and governmentregulation, are argued to be the more principal reason why public sector organizations choose to engage in sustainability reporting than a legitimacy one (Lodhia et al., 2012).

\subsection{Theoretical Framework: Institutional Theory}

A number of theoretical frameworks have been developed to explain organizational behavior with respect to sustainability reporting. Previous studies on sustainability reporting in both the private and public sectors have utilized institutional theory to guide their research. For example, in examining the CSR practices of Malaysian Corporations, Amran \& Devi (2007) utilized institutional theory. Goswami and Lodhia (2012) used institutional theory to draw inferences on the motives and influences of sustainability reporting in South Australian local councils.

Institutional theory posits that organizations operating in similar environments adopt homogenous organizational strategies, structures and processes in an effort to conform to societal norms, values and expectations (DiMaggio \& Powell, 1983). Organizations conform to such institutional pressures in order to gain legitimacy from the institutional environment in which they operate. Many institutional theorists, such as Meyer and Rowan (1977), and DiMaggio and Powell (1983) have based their studies on institutional isomorphism. Institutional isomorphism is based on the notion that institutions construct an institutionalized environment of accepted behaviors and 
actions; and deviation from the norm may impede on the survival of the organization. DiMaggio and Powell (1983) assert that organizations will adopt similar structures as a result of three isomorphic pressures: coercive, mimetic and/or normative pressures within the institutional field it is embedded.

Coercive isomorphism is manifested by an organization's informal and formal pressures exerted from external institutions to which the organization is dependent, and cultural expectations bounded within its domain. For example, research by Ioannou and Serafeim (2014) indicates that the introduction of mandatory sustainability reporting regulations leads to higher corporate sustainability disclosure. Mimetic isomorphism is driven by the idea that organizations faced with uncertain and unclear organizational objectives will mimic the actions of another organization within their environment they deem as being legitimate (Haverman, 1993; Goswami and Lodhia, 2012). For example, a municipality may compare itself against similar or bigger municipalities whom it regards as best practicing (Goswami and Lodhia, 2012). Normative isomorphism describes the pressure for an organization or individual to align its behavior with the norms of the occupation or profession it belongs to in order to appear legitimate. DiMaggio and Powell (1983) asserts that normative isomorphism becomes greater as occupations become increasingly professionalized. This is done through increased academic qualifications and participation in professional and trade associations. For example, a mining company may choose to adopt an environmental policy based on what is deemed as industry standard. Thus, the actions of an organization could be regarded as a by-product of the organizational field to which it belongs, "although the organization does not merely react passively to dictates by the field either" (DiMaggio and Powell, 1983). 
Institutional theory is particularly relevant for this study, whereby organizations in the public and private sectors are embedded within different institutional constructs. Therefore, institutional theory can provide a basis for understanding the key differences in the private and public sector with respect to their sustainability reporting practices. It is also of particular relevance as it provides a useful lens in describing the source of pressure that influence an organizations decision to report on their sustainability performance.

\subsection{Trade-Offs and Sustainability Reporting}

One of the most contentious issues when it comes to sustainability reporting is dealing with trade-offs. In addition to the inherently different theoretical motivators that public and private sector organizations face, disparities in trade-offs also contribute to the challenge of fostering greater alignment between the two sectors. Trade-offs are primarily an issue of resource management. They are a result of competing objectives and interests and limited resources. Haffar and Searcy (2015, p.7-8) explain, "trade-offs can be described as decisions made under resource constraints, among competing decision outcomes (e.g., reduced emissions vs. reduced water usage), and under competing decision objectives (e.g., responding to local community vs. consumers globally)." Thus, trade-offs require decision-makers to weigh the loss of one outcome against another.

Indeed, private and public sector organizations will typically have different goals, objectives, interests and available resources. For instance, public sector organizations may have less resources (i.e. financial resources and/or human capital) to allocate to sustainability reporting than their private sector counterparts. Furthermore, according to a 2013 survey conducted by the Boston College Center for Corporate Citizenship and Ernest \& Young LLP, private companies are more likely to view sustainability reporting as an opportunity to manage risk than organizations in 
the public sector. Such disparities between the two sectors may result in different trade-offs. The differences in these trade-offs that private and public sector organizations encounter may act as a barrier for the linking of reporting practices. Commitment to linking private and public sector sustainability reporting will likely depend on organizations' perception of the trade-offs involved in linking reporting. Thus, understanding the trade-offs involved is a vital part of making sustainability reporting more effective.

\subsection{Current Efforts and the SDGs}

The linking of public and private sector sustainability reporting has only very recently been identified as an important area of research. To date, only a few studies have explored the coherence between public and private sector reporting (namely Hoekstra et al., 2014 and Van der Esch and Stuerer, 2014). However, many researchers have identified the importance linking reporting. For instance, Dumay et al., (2010) asserted the "approach to an effective sustainability narrative needs to be done in a way that not only removes the 'blur' between the private and public sector, but for the sake of sustainability, it needs to remove the need to delineate between different organizations".

The emerging interest in this topic by academics and practitioners alike may be largely attributed to the recent adoption of the UN Sustainable Development Goals (SDGs) by the United Nations General Assembly as the universal 2030 Agenda for Sustainable Development. The UN SDGs were launched in September 2015, and are comprised of 17 ambitious goals and 169 accompanying targets that aim to holistically address sustainable development over the 2016-2030

period. They are an extension of the Millennium Development Goals (MDGs), which expired in 2015 (UN, 2015). Table 2 provides a list of the 17 SDGs.

Table 2: The United Nations 17 Sustainable Development Goals 17 United Nations Sustainable Development Goals

Goal 1 End poverty in all its forms everywhere 


\begin{tabular}{|c|c|}
\hline \multicolumn{2}{|r|}{17 United Nations Sustainable Development Goals } \\
\hline Goal 2 & $\begin{array}{l}\text { End hunger, achieve food security and improved nutrition and promote } \\
\text { sustainable agriculture }\end{array}$ \\
\hline Goal 3 & Ensure healthy lives and promote well-being for all at all ages \\
\hline Goal 4 & $\begin{array}{l}\text { Ensure inclusive and equitable equality education and promote lifelong } \\
\text { learning opportunities for all }\end{array}$ \\
\hline Goal 5 & Achieve gender equality and empower all women and girls \\
\hline Goal 6 & Ensure availability and sustainable management of water and sanitation for all \\
\hline Goal 7 & Ensure access to affordable, reliable, sustainable and modern energy for all \\
\hline Goal 8 & $\begin{array}{l}\text { Promote sustained, inclusive and sustainable economic growth, full and } \\
\text { productive employment and decent work for all }\end{array}$ \\
\hline Goal 8 & $\begin{array}{l}\text { Promote sustained, inclusive and sustainable economic growth, full and } \\
\text { productive employment and decent work for all }\end{array}$ \\
\hline Goal 9 & $\begin{array}{l}\text { Build resilient infrastructure, promote inclusive and sustainable } \\
\text { industrialization and foster innovation }\end{array}$ \\
\hline Goal 10 & Reduce inequality within and among countries \\
\hline Goal 11 & Make cities and human settlements inclusive, safe, resilient and sustainable \\
\hline Goal 12 & Ensure sustainable consumption and production patters \\
\hline Goal 13 & Take urgent action to combat climate change and its impacts* \\
\hline Goal 14 & $\begin{array}{l}\text { Conserve and sustainably use the oceans, seas and marine resources for } \\
\text { sustainable development }\end{array}$ \\
\hline Goal 15 & $\begin{array}{l}\text { Protect, restore and promote sustainable use of terrestrial ecosystems, } \\
\text { sustainably manage forests, combat desertification, and halt and reverse land } \\
\text { degradation and halt biodiversity loss }\end{array}$ \\
\hline Goal 16 & $\begin{array}{l}\text { Promote peaceful and inclusive societies for sustainable development, provide } \\
\text { access to justice for all and build effective, accountable and inclusive } \\
\text { institutions at all levels }\end{array}$ \\
\hline Goal 17 & $\begin{array}{l}\text { Strengthen the means of implementation and revitalize the global partnership } \\
\text { for sustainable development }\end{array}$ \\
\hline
\end{tabular}

Source: https://sustainabledevelopment.un.org/sdgs The full list of accompanying targets can be found at https://sustainabledevelopment.un.org/sdgs

Unlike the MDGs, which for the most part, overlooked the inclusion of the private sector from its discussion, the SDGs recognize the importance of leveraging the private sector as a powerful agent in achieving the global goals. Supporting this, Van der Esch \& Stuerer (2014) stated that sustainability is an inherently dynamic concept, one that cannot be accurately reported on by governments or the private sector alone. Instead, organizations, irrespective of sector, must be working in partnership towards advancing these mutually accepted and approved sustainability 
goals and targets. Therefore, linking sustainability reporting could be an important first step toward connecting private sector contributions to public goals.

The efforts to foster stronger linkages between public and private sector sustainability reporting centered around the SDGs is already occurring. In a joint venture between the Global Reporting Initiative, World Business Council for Sustainable Development, and United Nations Global Compact, an initiative called the SDG Compass has been developed. The purpose of the SDG Compass is to provide a guide to the private sector on how they can contribute to the SDGs through strategic action on their core business activities, and how they can effectively report on them (GRI, UNGC and WBCSD, 2015)

Another initiative called the Measure What Matters (MWM) project, has been actively promoting the need for greater alignment between corporate, national and global sustainability data frameworks since 2013. The project consortium, to which the GRI is a part of, is analyzing the alignment of various measurement systems across these domains to identify areas of alignment. Its efforts have included the convening of expert group meetings, stakeholder dialogue, and online consolation via its website (www.measurewhatmatters.info). Like the SDG Compass, the MWM realizes the potential for the SDGs to serve as a framework for business sustainability performance. However, it identifies itself as a longer term 'facilitator of alignment' between international, national and corporate levels. (Measure What Matters, 2014). Despite the aforementioned initiatives, there still remains a lack of practical experience and research on linking public and private sector sustainability reporting. Van der Esch \& Stuerer (2014) stressed the urgency for additional research on linkages between public and private sector sustainability monitoring and reporting to be conducted. 


\subsection{Literature Review Conclusion}

The extant literature demonstrates that progress toward sustainability reporting have been made by both private and public-sector organizations, and that sustainability reporting is growing steadfastly in both sectors. At the same time, the literature notes that the field is still clouded by a lack of clear definitions, confusion around best practices and insufficient reporting tools (London, 2012). Although the GRI has been established as the "de-facto" standard for sustainability reporting in both private and public sector organizations, research shows that there continues to exist major discrepancies between the reports produced by different types of organizations, and organizations operating in different industries and sectors (Hahn and Kuhnen, 2013). However, these two types of organizations have openly argued that they are committed to robust and transparent sustainability reporting (Crespy and Miller, 2011). Despite their public claims for robust sustainability reporting, there has been little harmony among the voices of public and private sector organizations (Crespy and Miller, 2011). Furthermore, organizations in the private sector have indicated their sustainability reporting practices have not been influenced by public policy, and that the GRI provides little guidance to organizations on this matter (Beare et al., 2014). The current diversity of methods and frameworks used within and across the public and private sector produce a fragmented picture of what constitutes sustainable development (Hahn \& Kuhnen, 2013; Hoekstra et al., 2014).

Although extensive work has been carried out on sustainability reporting in the private sector (Davis and Searcy, 2010; Roca and Searcy, 2012; Hahn and Kuhnen, 2013), there has been far less discussion in this respect regarding public sector organizations; notable exceptions include Farneti and Guthrie (2009); Lodhia et al., (2012); Alcaraz-Quiles et al., (2014). Even more so, little has been carried out on the coherence between private and public sector sustainability 
reporting practices. Therefore, awareness surrounding the linkages between public and private sector sustainability reporting remain poorly understood. In light of this, research which seeks to establish improved linkages between sustainability reports for public and private sector organizations may produce findings of considerable value. 


\section{$3 \quad \underline{\text { Research Questions }}$}

This research seeks to investigate the key linkages between public and private sector sustainability reporting in order to determine how closer alignment may be fostered. The research question(s) that guide this study are:

1. What are the similarities and differences of sustainability reporting between the public and private sector?

2. What are the potential benefits and risks of linking reporting between public and private sector sustainability reporting?

3. What are barriers and challenges that may inhibit such alignment between private and public sector sustainability reporting from materializing?

4. What are the trade-offs of linking reporting between public and private sector sustainability reporting? 


\section{Methods}

In order to address the research question(s), a content analysis of sustainability reports coupled with semi-structured interviews with experts in the field were conducted. The content analysis included sustainability reports published by both private (Canadian corporations) and public (Canadian government) organizations, which totaled a cumulative sample of 109 reports. The sustainability reports were manually screened, providing insight into the extent to which Canadian organizations were disclosing sustainability information and where greater alignment could be fostered between the two sectors. In addition to the content analysis, semi-structured interviews were conducted with experts in the field of CSR and sustainability reporting. An overview of the research method used in this study is illustrated in Figure 1.

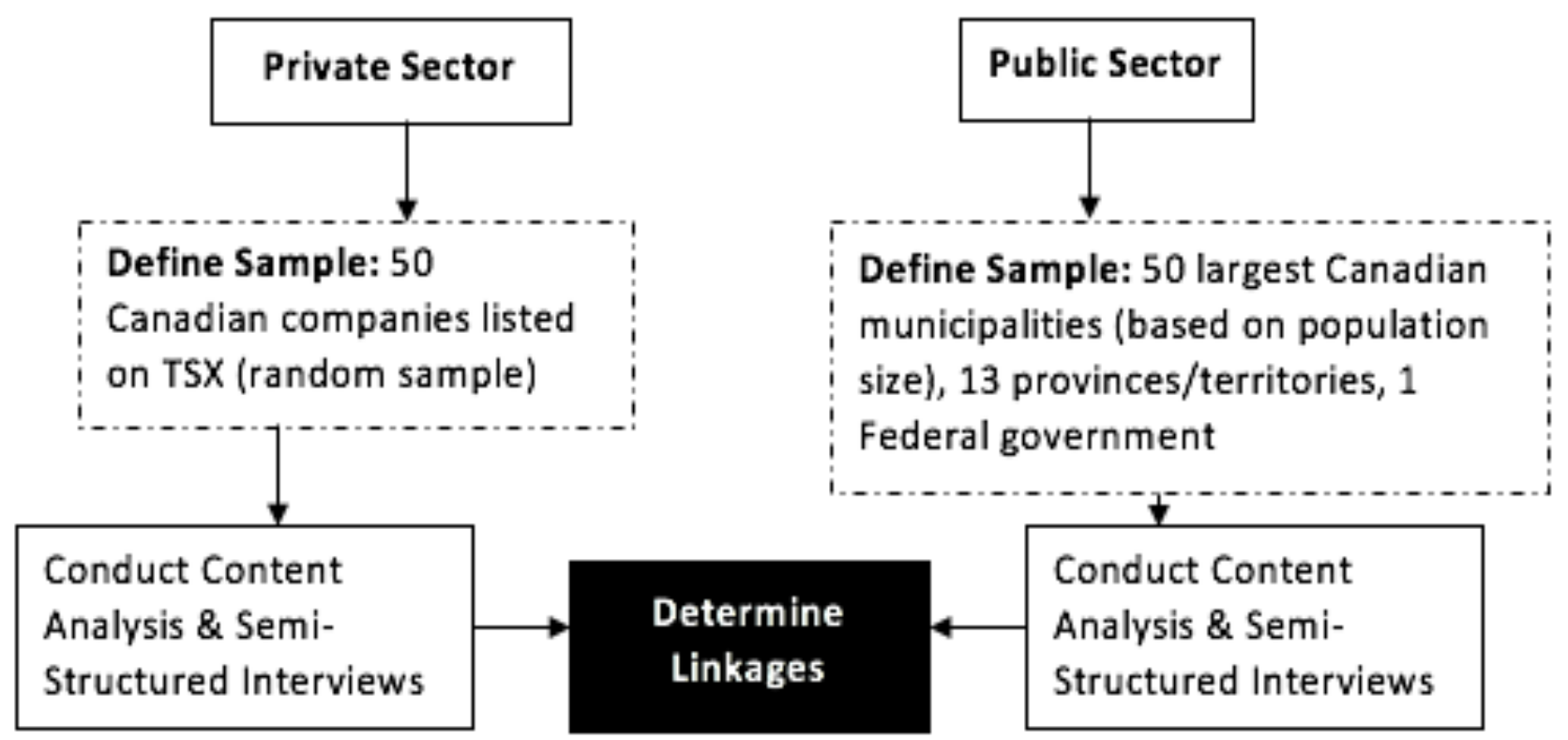

Figure 1: Overview of Methods 


\subsection{Sample Selection}

This study employed a case study approach, focusing on Canada. While it is important to understand that case study analysis may not be seamlessly applied to other contexts, it is still a useful method, especially when investigating research that is emerging (Yin, 2009). Canada is located in the northern part of North America, and is comprised of ten provinces and three territories. It has a population of over 36 million people and is the world's second largest country by land area (Statistics Canada, 2016). Due to its abundance in natural recourses, Canada is involved in many activities such as mining, oil and gas extraction, energy and forestry (Roca \& Searcy, 2012). It is not legally required for organizations to produce sustainability reports in Canada. However, Canadian banks, insurance companies trust and loan companies are required to publish a public accountability statement (CGA-Canada, 2005). The analysis excluded organizations, such as non-profit organizations, Co-ops, Credit Unions, Institutes, Universities, Crown corporations, Associations.

\subsubsection{Private Sector Sample Selection}

For the private sector, sustainability reports were drawn from a random sample of 50 Canadian companies listed on the Toronto Stock Exchange (TSX). Utilizing the TSX enabled a broad representation of companies, across varying industry sectors and reporting experience (CGA-Canada, 2005). The study initially proposed a random sample of 25 Canadian companies listed on the S\&P/TSX and 25 Canadian companies listed on Canada's junior market, the TSX Venture Exchange. Existing literature on corporate sustainability reporting has been dominated by a focus on larger companies, or companies that are more advanced in their sustainability reporting initiatives. Utilizing the TSX Venture Exchange would have proven a broader sample than the TSX alone, "across varying sizes, industry sectors and reporting experience" (CGA-Canada, 
2005). However, the random sample revealed that there were very few companies listed on the TSX Venture Exchange that published a formal sustainability report or disclosed sustainability related information on their website. As a result, it would not have provided an adequate sample to draw any significant conclusions from (see Appendix A for the 25 companies listed on TSX Venture Exchange excluded from the sample).

To ensure that the sample was not dominated by one industry, a stratified proportionate random sample technique was employed. Employing a technique similar to Daub (2005), a list of all companies listed on the TSX was exported from the TSX website (https://www.tmx.com/) into an excel spreadsheet. Using the random sample sort function in Excel, each company was assigned a number and randomly sorted. Companies were then selected until at least 5 companies were selected for five different industries, and until a total of 50 companies were selected altogether. The industries used for the stratified sample were (1) Mining, (2) Oil \& Gas, (3) Financial Services/Banks, (4) Food \& Retail, (5) Engineering, Construction and Industrial Manufacturing. Therefore, at least 25 organizations belonged to one of these five categories. Upon an initial assessment of the organizations listed on the TSX, it was evident that these five industries were the most dominant. Therefore, the study chose to focus on them to ensure enough organizations adequately filled each category to be able to draw statistical inferences. A sixth category was added to include all other organizations that did not fall into one of the five pre-determined industry categories. Table 3 outlines the list of private sector organizations included in the sample, as well as the their industry.To ensure consistency, all of the reports analyzed from the private sector were the most current report published.

Therefore, all private sector organizations met the following criteria:

1. Canadian based company listed publicly on the Toronto Stock Exchange (TSX) 
2. Published a sustainability report or equivalent

3. Report available in English

Table 3: Sample of TSX listed Canadian organizations and their industry

\section{Organization}

Algoma Central Corporation

Arc Resources Limited

Artis REIT

Aura Minerals Inc.

Avalon

Bank of Montreal (BMO)

Barrick Gold

Bell Canada

Blackberry

Bombardier Inc.

Canfor Corporation

Capstone Mining Corporation

Catalyst Paper

Celestica

CGI Group Inc.

Canadian Imperial Bank of Commerce (CIBC)

Cogeco Cable

Domtar Inc.

EnCana

First Quantum Minerals

Genworth MI Canada

Gold Corp Inc.

Great-West Lifeco

Highliner Foods Canada

Husky Energy Inc.

IAMGOLD Corporation

IGM Financial Inc.

Imperial Oil Ltd.

Innergex Renewable Energy Inc.

Kinross Gold

KP Tissue Inc.

Loblaws Companies Ltd

Lundin Mining Corporation

Maple Leaf Foods Inc.

Metro

Morgaurd Corporation

Newalta Corporation

Progressive Waste Solutions

Rogers Communications

\section{Industry}

Shipping Services

Oil \& Gas

Real Estate Investment Trust

Mining

Mining

Banking

Mining

Telecommunications

Telecommunications

Engineering and Manufacturing

Forestry \& Paper

Mining

Forestry \& Paper

Electronic Manufacturing

Information Technology Consulting

Banking

Media/ Telecommunications

Forestry \& Paper

Oil \& Gas

Mining

Insurance

Mining

Insurance

Food Retailer

Oil \& Gas

Mining

Financial Services

Oil \& Gas

Energy

Mining

Consumer Goods/Retailer

Food \& Beverage Retailer

Mining

Food Retailer

Food \& Beverage Retailer

Real Estate

Industrial Manufacturing (Waste

Management)

Waste Management

Telecommunications 


\begin{tabular}{lll}
\hline Organization & Industry \\
\hline RONA Inc & Retailer \\
\hline SEMAFCO & Mining \\
\hline Sherritt International Corporation & Mining \\
\hline Suncor Energy & Oil \& Gas \\
\hline Sunlife Financial & Financial Services (Insurance) \\
\hline TD Financial Group & Banking \\
\hline Teck Resources & Mining \\
\hline Telus Corporation & Telecommunications \\
\hline TransAlta Corporation & Electricity \\
\hline TransCanada Corporation & Oil \& Gas \\
\hline West Fraser Timber Co. Ltd. & Forestry \& Paper \\
\hline
\end{tabular}

\subsubsection{Public Sector Sample Selection}

For the public sector, sustainability reports from the municipal, provincial and federal government were used. Municipalities were selected from the 50 largest cities and towns based on population size in Canada. This was taken directly from the Statistics Canada website (http://www.statcan.gc.ca/). Focusing on large municipalities over small municipalities is justified for a number of reasons and is consistent with the approach taken by other researchers in this area of study (Alcaraz-Quiles et al., 2014). Generally speaking, municipalities with large populations are likely to be exposed to a larger number of stakeholders, have more resources available to them, and retain employees with higher managerial skills (Alcaraz-Quiles et al., 2014). As a result, large municipalties may be better positioned to produce sustainability reports (Alcaraz-Quiles et al., 2014).

Reports from the public sector were reviewed to be determined if they could be categorized as a sustainability report/plan, state of environment report (SOER) and/or strategic plan. Issuespecific reports and/or department-level reports, such as climate action plans, natural resource plans, forest management plans, transportation plans, etc) were excluded from the content analysis. Instead, the study chose to focus solely on reports that were considered the highest level document that guided the organization's overall sustainability initiatives. The reason for this is two-fold. 
Firstly, it is extremely challenging to evaluate the content of such a large number of very different reports. Secondly, the focus was on how public sector organizations are reporting on progress towards sustainability in a holistic way in order to assess the jurisdiction's overall performance and communicate that to its constituents.

Table 4 provides a list of public sector organizations included in the study. Data limitations included inaccessibility/non-availability of reports in English for four Quebec municipalities, and therefore the sample did not include them. Although the Province of Quebec released a sustainability report, only a summary version was available in English. The summary report was still considered, but it should be noted that this prevented a full analysis of the report. Furthermore, New Brunswick last published a report in 2003, and Manitoba last published a report in 2009. As such, these reports were considered too out of date for the study. Furthermore, Ontario, Newfoundland and Nunavut did not publish a report that met the criteria of the study. Therefore, the reports were collected from the web sites of 50 municipalities, 8 provinces/territories and one report was drawn from the federal Government of Canada (59 reports). To ensure consistency, all of the reports analyzed were the most recent report published.

The sample of public sector organizations met the following criteria:

1. Municipal, provincial or federal government of Canada

2. Published a sustainability report, SOE report or strategic plan no older than 2010

3. Report available in English

Table 4: Sample of public sector organizations

\section{Local/Regional Government (50)}

\begin{tabular}{|l|l|l|l|l|}
\hline Burlington & Halifax & Richmond Hill & Kingston & Delta \\
\hline Calgary & London & Oakville & Whitby & Waterloo \\
\hline Ottawa & Markham & Toronto & Guelph & Cape Breton \\
\hline
\end{tabular}




\begin{tabular}{|l|l|l|l|l|}
\hline \multicolumn{2}{|l|}{ Local/Regional Government (50) } & Greater Sudbury & Kelowna & Brantford \\
\hline Edmonton & Vaughan & Oshawa & Saanich & Strathcona County \\
\hline Mississauga & Burnaby & Barrie & Ajax & Red Deer \\
\hline Winnipeg & Saskatoon & Abbotsford & Thunder Bay & Pickering \\
\hline Vancouver & Kitchener & St. Catharine's & St Johns & Kamloops \\
\hline Brampton & Windsor & Cambridge & Langley & Clarington \\
\hline Hamilton & Regina & Coquitlam & Chatham-Kent & North Vancouver \\
\hline Surrey & Richmond & &
\end{tabular}

Provincial/Territorial and Federal Government (9)

\begin{tabular}{|l|l|l|l|l|}
\hline Alberta & Quebec & British Columbia & Nova Scotia & Saskatchewan \\
\hline $\begin{array}{l}\text { Northwest } \\
\text { Territories }\end{array}$ & Yukon & $\begin{array}{l}\text { Prince Edward } \\
\text { Island }\end{array}$ & Canada & \\
\hline
\end{tabular}

\subsection{Content Analysis}

Similar studies on sustainability reporting have employed a content analysis method (Gray et al., 1995). Content analysis is described by Krippendorf (1980) as a "research technique for making replicable and valid interences from data to their contexts". The literature notes that one of the major benefits of a content analysis is that it can be used to capture and describe a large amount of data into highly descriptive codes that can be mined to produce robust analysis (Gaither, 2007). For this study, a content analysis of sustainability reports, or equivalent, from both public and private sector organizations is ideal for understanding the similarities and differences of sustainability disclosure. In addition to sustainability reports, the study also chose to analyze organizational websites for sustainability disclosure. Several researchers have pointed to the emerging trend toward online sustainability disclosure among both the private and public sector organizations (Corina et al., 2014). Therefore, sustainability reports and organizational websites are justified as the main units of analysis in this study. Given the voluntary nature of sustainability 
reporting, the validity of reports as a measure of actual performance has been questioned. However, this study chose to follow the notion highlighted by Krippendorf (1980) that the extent of information included in the report can provide an indication of its significance to the organization.

\subsubsection{Data Collection Procedure}

The sustainability report was selected for inclusion in the content analysis by searching the organization's website. Search tools were used to ensure adequate due diligence during the report identification and collection phase. Commonly cited report terms identified in the literature, such as "Sustainability" and "Corporate Social Responsibility" were entered into the search queue of the organizations website. After identifying the appropriate reports, each report was downloaded and saved in a PDF format. This was to ensure that the data being analyzed was consistent with the time it was downloaded. In addition to the sustainability report, organizational websites were also examined. In order to ensure consistency of the data, all websites were accessed during the months of February and March 2016. It is important to examine all websites within a specified time-frame as the content of websites change frequently. An Excel sheet was created to structure and store the texts of the reports and to facilitate the analysis of the material.

The reports were manually read to ensure all relevant data were considered and recorded. The decision to exclude the use of a computer-assisted software program was made in consideration of the purpose and goal of the research. Given the exploratory nature of the research, manual analysis of sustainability reports and interview transcripts were more appropriate. Using technology in qualitative research may distance the researcher from the data, impairing a more indepth analysis required for exploratory research (St John \& Johnson, 2000). 
Once the sample of reports for the study was established, a content analysis of the reports was conducted in order to address the research questions. In order to ensure a complete coding effort, each sustainability report was reviewed twice. Data was extracted by copying and pasting the text material directly from the report PDF and/or website into an Excel spreadsheet. Three worksheets were developed to organize and store the results for each organization. The first worksheet was used to store general background information of the report, including title of report, number of pages, year of publication, and the standardized reporting guideline used in the report if any (by column). Keywords in each column (GRI, ISO 14001, SDGs, UNGC, Carbon Disclosure Project etc.) were manually searched in each report. These keywords were chosen because they were identified in the literature review as the most prominent reporting tools oriented towards both the public and private sectors. If the organization was following one of these reporting guidelines/principles, a "Y" representing a "yes" was recorded in the column beside the organizations name.

The second worksheet was used to store the different goals and targets that the organization publicly committed themselves to by discussing them in either their sustainability reports and/or websites. These goals defined an intention to address sustainability issues material to the organization. Based on the coding rules and boundaries defined, only goal/targets that were formally presented as goals/ targets by the organization within the report/website were considered for the study. Goals/targets were considered "formal sustainability goals" if they were distinctly labelled in the report and/or website as a goal, target and/or objective within the text, in bold letters, contained within a scorecard, chart/table, textbox and/or bullet point and/or had a clear measurement criterion. The study chose to focus solely on goals/targets that the organization has already clearly established and committed themselves to. Therefore, goals to create a goal $/$ target 
were excluded from the analysis (i.e. "set GHG reduction targets"). Deductive categories were initially formed based on past research, coupled with a preliminary review of the sustainability reports. Resources used included pivotgoals.com which helped formulate preliminary goal categories. This preliminary goal list was then later altered, changed, added to and eliminated from as the content analysis was carried out. Examples of the keywords included: energy reduction/consumption, GHG reductions, alleviating poverty, water reductions/consumption, sustainable land use/development etc. The third worksheet was used to store the quotes that made reference to the other sector in their sustainability reports and/or websites. Extracting such information provides a basis for understanding the current relationship and dialogue between the two sectors, and provides an opportunity to determine areas of alignment. Keywords were logically formed and manually searched for throughout the report using the search queue function of the PDF file. These included phrases such as: public policy, government, regulation, private, public, organization, company, business, industry/sector. Themes and patterns emerged through the analysis of the context of these key words. The quote was copied and pasted into the excel worksheet, along with the location and organization to which it belonged. Table 5 summarizes the key data variables extracted during the content analysis and the rationale for its inclusion.

Table 5: Content Analysis key variables, description and rationale for inclusion

\begin{tabular}{|l|l|l|}
\hline Key Variable & Description & Rationale for Inclusion \\
\hline $\begin{array}{l}\text { Sustainability } \\
\text { Report }\end{array}$ & $\begin{array}{l}\text { Availability of sustainability report or } \\
\text { equivalent }\end{array}$ & $\begin{array}{l}\text { To determine trends in report types published by } \\
\text { each sector }\end{array}$ \\
\hline $\begin{array}{l}\text { Sustainability } \\
\text { (website) }\end{array}$ & $\begin{array}{l}\text { Sustainability data available on } \\
\text { organizational website }\end{array}$ & $\begin{array}{l}\text { To determine if organizations are moving } \\
\text { towards online reporting }\end{array}$ \\
\hline Publication Year & $\begin{array}{l}\text { Year of publication of most recent } \\
\text { report }\end{array}$ & $\begin{array}{l}\text { To determine frequency of reporting and/or how } \\
\text { up-to-date/relevant report content is }\end{array}$ \\
\hline Length of report & No. of pages in the sustainability report & $\begin{array}{l}\text { To determine trends in quantity of sustainability } \\
\text { information disclosed by each sector }\end{array}$ \\
\hline Name of report & Title of report & $\begin{array}{l}\text { To determine report types published by each } \\
\text { sector }\end{array}$ \\
\hline
\end{tabular}




\begin{tabular}{|l|l|l|}
\hline Key Variable & Description & Rationale for Inclusion \\
\hline $\begin{array}{l}\text { Reporting } \\
\text { and Standards }\end{array}$ & $\begin{array}{l}\text { Global Reporting Initiative: Report } \\
\text { references the GRI } \\
\text { Carbon Disclosure Project: } \\
\text { Organization provides information to } \\
\text { the CDP } \\
\text { GHG Protocol: Organization provides } \\
\text { information to GHG protocol } \\
\text { ISO 14001: } \\
\text { Organization is registered to ISO 14001 } \\
\text { UNGC: } \\
\text { Organization adheres to the UNGC }\end{array}$ & $\begin{array}{l}\text { To determine the similarities/differences in } \\
\text { reporting guidelines used. The study chose to } \\
\text { focus on these as they were identified in the } \\
\text { oriented towards both the public and private } \\
\text { sectors. }\end{array}$ \\
\hline $\begin{array}{l}\text { Sustainable } \\
\text { Development } \\
\text { Goals (SDGs) }\end{array}$ & $\begin{array}{l}\text { Report mentions the SDGs in } \\
\text { sustainability report and/or website }\end{array}$ & $\begin{array}{l}\text { Provide insight into organizations' willingness } \\
\text { to utilize SDGs as a tool for linking reporting }\end{array}$ \\
\hline $\begin{array}{l}\text { Quotes referencing } \\
\text { each other }\end{array}$ & $\begin{array}{l}\text { Organization references the opposing } \\
\text { sector in their sustainability report } \\
\text { and/or website }\end{array}$ & $\begin{array}{l}\text { Provides insight into the current } \\
\text { relationship/dialogue between sectors and } \\
\text { highlights potential areas for linking reporting }\end{array}$ \\
\hline
\end{tabular}

\subsubsection{Pilot Test}

Prior to conducting the full content analysis, a pilot study to assess intra-rater reliability was first carried out. Conducting a pilot study is a critical component of the content analysis, as it helps researchers to determine whether or not information being obtained is consistent (Cargan, 2007). Intra-rater reliability is measured by the degree of consistency between ratings performed by a single rater, under identical conditions. According to Neuendorf (2002), the acceptable size of the pilot sample should be no less than $10 \%$ of the full sample. Therefore, a sample of 12 sustainability reports ( 7 from the public sector and 5 from the private sector) representing $10 \%$ of the main study population was randomly selected. This was done using the Excel random sample sort function. The pilot test was conducted between two time points (Test 1 and Test 2), carried out one week a part under similar conditions. According to Landis \& Koch (1997), an acceptable score of intra-rater reliability is between $0.61-0.80$. The pilot test produced a score of 0.86 . Since the pilot test achieved an appropriate level of validity and reliability, the full sample of reports was carried out. 


\subsection{Semi-Structured Interviews}

In addition to the content analysis, semi-structured interviews were conducted. In contrast to structured interviews, which include a rigorous set of questions that cannot be diverted from, semi-structured interviews are conducted with a fairly open and flexible framework. This flexibility allows the researcher to probe further into relevant issues previously unknown to the researcher (Segal et al., 2006).

The literature notes that because questions in semi-structured interviews are generally predetermined, this method can promote reliability in the research (Segal et al., 2006). Thus, the use of semi-structured interviews with sustainability reporting experts can yield reliable and valid findings that show the key issues in sustainability reporting as perceived by experts in the field. The interviews allowed sustainability managers, or equivalent, to explain their approach on many issues raised from the content analysis, such as how the goals and targets were selected for disclosure in the report. Participants were asked about how sustainability reporting between the private and public sector can be more closely aligned, what the benefits and risks are of closer alignment and what they perceive as the barriers and challenges to closer alignment (see Appendix F for interview questionnaire guide).

A letter of introduction along with a consent form was sent via email to the organizations whose reports were reviewed in the content analysis, explaining the purpose of the study and requesting their participation in the interview process. This helped to ensure that a variety of individual perspectives in both the private sector and the public sector were included in the analysis. Interview subjects were primarily CSR and Environmental Managers, and others leading similar initiatives in these organizations. In cases where information on individuals serving in these roles were not publicly available via a website, the information was obtained by telephoning the 
organization and seeking out the appropriate party. If a response was not received within 3 weeks of the initial mail-out, one follow-up e-mail was sent out (see Appendix E and D for email invitation and consent form).

A total of 22 in-depth interviews were conducted with sustainability reporting professionals. Although the study aimed for a balanced representation of participants from both sectors, the response rate was higher for the public sector $(25 \%)$ than the private sector $(14 \%)$. This posed a limitation to the study that cannot be controlled. On average, each interview lasted between 20-40 minutes. All interviews were conducted over the phone, and all interviews were audio-recorded and later transcribed. The interviews were carried out within the months of May to August, 2016. Table 6 provides a list of interview participants by sector and their position title. Participants generally held top-level positions, including senior, director, and manager positions. Given the confidentiality of the study, further details on the participant and the organization to which they are employed is not disclosed.

Table 6: List of Interview participants

\begin{tabular}{|l|l|l|}
\hline Participant \# & Sector & Position Title \\
\hline Participant 1 & Public & Sr. Sustainability Coordinator \\
\hline Participant 2 & Public & Manager, Sustainability \\
\hline Participant 3 & Public & Sustainability Coordinator \\
\hline Participant 4 & Public & Community Energy Specialist \\
\hline Participant 5 & Public & Manager, Strategic Initiatives \& Sustainability \\
\hline Participant 6 & Public & Supervisor, Environmental Sustainability and Climate Change \\
\hline Participant 7 & Public & Senior Environmental Policy Planner \\
\hline Participant 8 & Public & Manager, Environmental Planning \\
\hline Participant 9 & Public & Sustainability Coordinator \\
\hline Participant 10 & Public & Sustainability Coordinator \\
\hline Participant 11 & Public & Sustainability Coordinator \\
\hline Participant 12 & Public & Manager of Environmental Services \\
\hline Participant 13 & Public & Sustainability Services Supervisor \\
\hline
\end{tabular}




\begin{tabular}{|l|l|l|}
\hline Participant \# & Sector & Position Title \\
\hline Participant 14 & Public & Sustainability Program Coordinator \\
\hline Participant 15 & Public & Sustainability Coordinator \\
\hline Participant 16 & Private & Senior Communications and Reporting Specialist \\
\hline Participant 17 & Private & Director, Health, Safety, Environmental and Social Responsibility \\
\hline Participant 18 & Private & Sr. Director, Corporate Social Responsibility \\
\hline Participant 19 & Private & Director, Corporate Responsibility and Strategy \\
\hline Participant 20 & Private & Senior Consultant - Sustainability \\
\hline Participant 21 & Private & Director, Sustainability \\
\hline Participant 22 & Private & Sr. Director, Health Safety and Environment \\
\hline
\end{tabular}

Using the five-step process developed by McCracken (1988) for analysis of long interviews, the interview transcripts were coded to extract themes and concepts that addressed the research questions. The first stage involved reading and reviewing the interview transcripts twice. This was done to first become familiarized with the data and to gain a general understanding of the content. The second phase included the formulation of inductive categories. These categories were based on the evidence presented in the transcripts, literature review and the institutional theory used to guide the research study. The third stage involved identifying patterns and connections among the categories. The fourth stage included developing themes based on the identified patterns. Ely et al., (1991) defined a theme as "a statement of meaning that runs through all or most of the pertinent data, or one in the minority that carries heavy emotional or factual impact" (p. 150). The final stage involved refining and finalizing themes which serve to answer the research questions.

\section{Results and Discussion}

\subsection{Sample Analysis \\ 5.1.1 Private Sector}


A large portion of the private sector sample was dominated by companies within the extractive industry (mining, oil \& gas, and electricity companies), which accounted for $38 \%$ of the sample in total. The mining industry alone comprised $24 \%$ of the private sector sample. This was to be expected as Canada is a leader in the mining and oil \& gas industry, with more mining and oil \& gas companies listed on the TSX than any other exchange in the world (KPMG, 2014). The financial industry accounted for $16 \%$ of reports analyzed. This can be attributed, at least in part, to the introduction of the Public Accountability Statement (PAS) mandatory reporting requirements in Canada in 2000 (CFERF, 2009). However, the financial industry, particularly banks, are susceptible to high social public visibility, and therefore are more likely to produce sustainability reports as oppose to lower-visibility industries. The breakdown of the number of private sector organizations per industry type, is provided in Table 7, along with a description of the industry. Figure 2 illustrates the percentage of private sector organizations per industry group.

Table 7: Number of private sector organizations per industry

\begin{tabular}{|l|l|c|}
\hline Industry & Description & $\begin{array}{l}\text { Number of } \\
\text { Organizations }\end{array}$ \\
\hline Mining & Mining & 12 \\
\hline Banks/Financial Services & $\begin{array}{l}\text { Banks } \\
\text { Insurance Companies } \\
\text { Real Estate \& Investment } \\
\text { Specialty \& Other Services }\end{array}$ & 9 \\
\hline $\begin{array}{l}\text { Food, Beverage \& Consumer } \\
\text { Goods }\end{array}$ & $\begin{array}{l}\text { Food \& Beverage } \\
\text { Beverages } \\
\text { Food producers } \\
\text { Household Goods \& Home } \\
\text { Leisure Good } \\
\text { Personal Goods } \\
\text { Food \& Drug Retailers } \\
\text { General Retailers }\end{array}$ & 6 \\
\hline $\begin{array}{l}\text { Engineering, Industrial } \\
\text { Manufacturing and }\end{array}$ & $\begin{array}{l}\text { Engineering \& Machinery } \\
\text { Construction \& Building Materials } \\
\text { Forestry \& Paper }\end{array}$ & \\
\hline
\end{tabular}




\begin{tabular}{|l|l|c|}
\hline Industry & Description & $\begin{array}{l}\text { Number of } \\
\text { Organizations }\end{array}$ \\
\hline Electricity/Oil \& Gas & $\begin{array}{l}\text { Oil \& Gas producers } \\
\text { Oil equipment, services and } \\
\text { distribution } \\
\text { Alternative energy }\end{array}$ & 9 \\
\hline $\begin{array}{l}\text { Transport, Communication and } \\
\text { Services }\end{array}$ & $\begin{array}{l}\text { Transport Services } \\
\text { Media, Entertainment \& } \\
\text { Broadcasting } \\
\text { Telecommunications } \\
\text { Information Technology (IT) }\end{array}$ & 7 \\
\hline
\end{tabular}

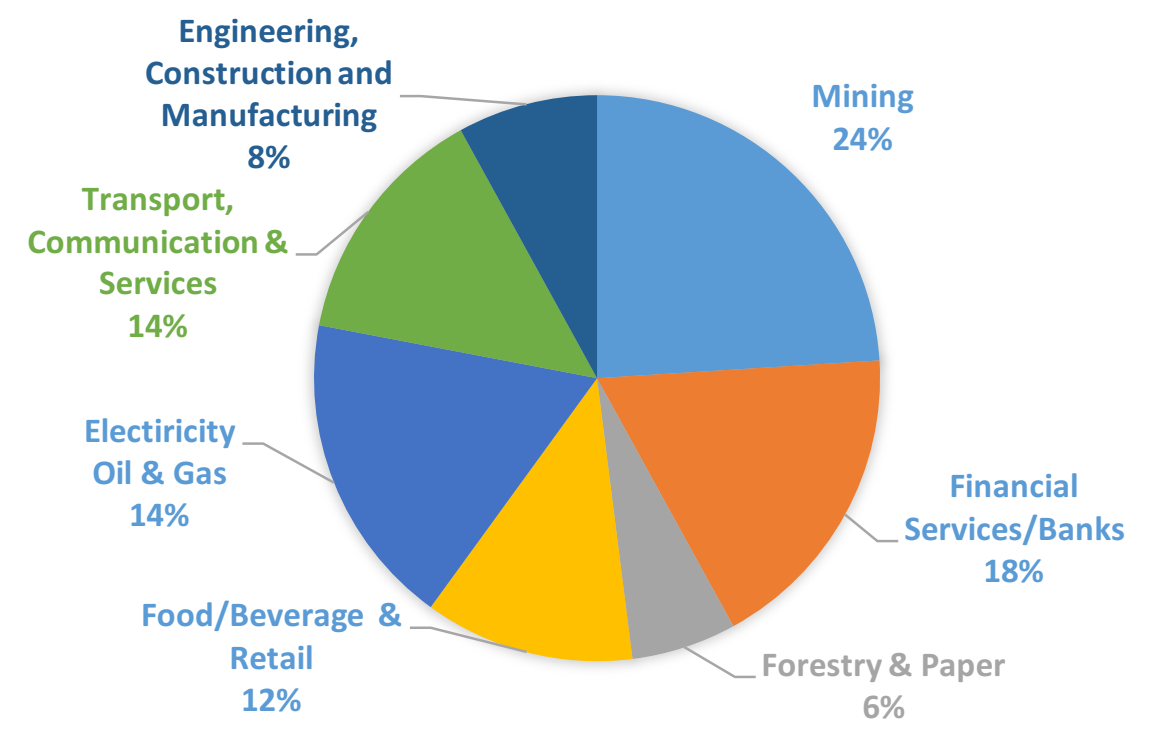

Figure 2: Percentage of private sector companies per industry group

\subsubsection{Public Sector}

The majority of local governments included in the content analysis were from the most populous Canadian jurisdictions (Ontario, British Columbia, and Alberta). More specifically, Ontario dominated half of the sample (56\%), while British Columbia covered almost a quarter of the sample (24\%). Figure 3 illustrates the percentage of local governments per province/territory included in the sample. 


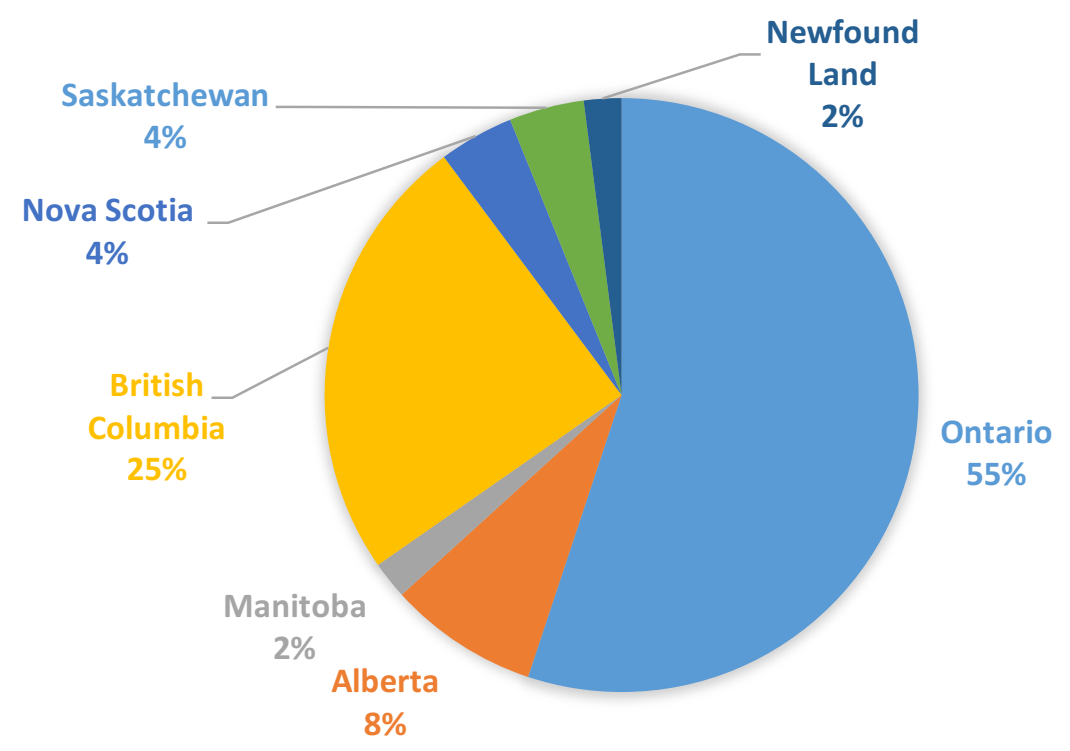

Figure 3: Percentage of local governments per Canadian province/territories

\subsection{Report Types}

\subsubsection{Private Sector}

The majority of the reports sampled from the private sector (approximately $75 \%$ ) can be categorized as either a stand-alone sustainability report (53\%), corporate social responsibility report (14\%) or responsibility report (12\%). Only 4\% of the reports were considered integrated, combining financial information with non-financial information. These reports were published by Bombardier Inc. (Activity Report) and TransAlta Corporation (Annual Integrated Report). Only one private sector organization (CGI Group), published an environmental report. As the title suggests, the scope of the report focused solely on environmental performance data. This affirms that stand-alone sustainability reports remain the most predominant type of report in this area published by private sector organizations.

In one case, a Food \& Retailer Company, Metro Inc., produced both an annual "Corporate Responsibility Report", and a long-term visionary plan, entitled "Corporate Sustainability Report 2020 Plan". The purpose of the 2020 Plan was to outline the organization's long term sustainability 
goals and targets, covering the years 2016 to 2020. In another case, the Bank of Montreal (BMO) produced a Corporate Responsibility Report, alongside its mandated Public Accountability Statement (PAS), titled "Environmental, Social and Governance Report and Public Accountability Statement". In these cases, all reports and documents were reviewed and the relevant data pertaining to the study was extracted. Table 8 provides a list of the report types produced by the private sector and their average lengths.

Table 8: Average length of private sector reports per report type

\begin{tabular}{|l|r|r|r|r|r|}
\hline Report Title & $\begin{array}{c}\text { Number } \\
\text { of } \\
\text { Reports }\end{array}$ & $\begin{array}{l}\text { Maximum } \\
\text { Length }\end{array}$ & $\begin{array}{l}\text { Minimum } \\
\text { Length }\end{array}$ & $\begin{array}{l}\text { Mean } \\
\text { Length }\end{array}$ & $\begin{array}{l}\text { Median } \\
\text { Length }\end{array}$ \\
\hline Sustainability Report & 26 & 176 & 4 & 54.7 & 40 \\
\hline Sustainable Development Report & 3 & 44 & 13 & 31 & 36 \\
\hline $\begin{array}{l}\text { Corporate Social Responsibility (CSR) } \\
\text { Report }\end{array}$ & 7 & 96 & 15 & 57.3 & 58 \\
\hline Responsibility Report & 6 & 155 & 24 & 64 & 51.5 \\
\hline $\begin{array}{l}\text { Public Accountability Statement } \\
\text { (PAS) }\end{array}$ & 2 & 60 & 16 & 38 & 38 \\
\hline $\begin{array}{l}\text { Environmental, Social and Governance } \\
\text { (ESG) Report and PAS }\end{array}$ & 1 & 70 & 70 & 70 & 70 \\
\hline Community Report & 1 & 36 & 36 & 36 & 36 \\
\hline Integrated Report & 1 & 202 & 202 & 202 & 202 \\
\hline Activity Report & 1 & 44 & 44 & 44 & 44 \\
\hline Corporate Citizenship Report & 1 & 14 & 14 & 14 & 14 \\
\hline Responsibility Report and PAS & 1 & 83 & 83 & 83 & 83 \\
\hline $\begin{array}{l}\text { Health, Safety and Sustainability } \\
\text { Report }\end{array}$ & 1 & Online & Online & Online & Online \\
\hline Environmental Report & 1 & 44 & 44 & 44 & 44 \\
\hline TOTAL & $\mathbf{5 2}$ & $\mathbf{2 0 2}$ & $\mathbf{4}$ & $\mathbf{5 3 . 6}$ & $\mathbf{4 4}$ \\
\hline
\end{tabular}

*Total equals 52 not 50 as two organizations (Metro Inc. and BMO) produced an additional report relevant to the study 


\subsubsection{Public Sector}

Consistent with the findings from the literature, public sector organizations communicate sustainability information through a number of different reports/plans produced across various public agency departments. These reports are either comprehensive or single-issue focused. The majority of the reports sampled (approximately 73\%) can be categorized as either a sustainability plan/report (28\%), environmental report (24\%) or strategic plan $(21 \%)$.

The general purpose of the sustainability plan/strategy report is to outline the long-term sustainability strategy or plan for the community. Much of the plans published by local/regional governments focused on the direction of land use and physical development of the region, and/or other areas under the organizations purview. For instance, the City of Kitchener states "although the plan is concerned mainly with land use and physical development of the city, it also aims to balance the social, economic and environmental interests of the community" (City of Kitchener, 2014). While 13\% produced an SOE report, much of the information included in an SOE report is information that would have otherwise been included in an environmental report/strategy. The scope of the SOE report generally included information on the environmental conditions of a specific geographical area (country, state, region, city or municipality). Despite some generalizations, report content, titles and format tended to vary between report types across the public sector. These differences clearly highlight the different views of public sector organizations on the most appropriate way of reporting on their sustainability performance. In turn, this further complicates the picture for stakeholders, as not all public sector organizations are clear about what kind of reports they have, and their corresponding purpose.

Table 9 provides a list of the different report types produced by public sector organizations, along with the maximum, minimum, mean and median length calculations. The City of Calgary 
and the City of Oakville both produced an additional report within the same year that met the criteria of the study. The City of Calgary produced a 2014 Corporate Environmental, Health and Safety Report as well as a 2014 Annual Report on its Sustainable Direction. The City of Oakville produced a 2014 environmental strategic report as well as a 2014 state of environment (SOE) report. In these cases, both reports were reviewed for analysis.

Table 9: Average length of public sector reports per report type

\begin{tabular}{|l|r|r|r|r|r|}
\hline Report Type & $\begin{array}{c}\text { Number } \\
\text { of Reports }\end{array}$ & $\begin{array}{c}\text { Maximum } \\
\text { Length }\end{array}$ & $\begin{array}{c}\text { Minimum } \\
\text { Length }\end{array}$ & $\begin{array}{c}\text { Mean } \\
\text { Length }\end{array}$ & $\begin{array}{l}\text { Median } \\
\text { Length }\end{array}$ \\
\hline State of Environment Report (SOE) & 8 & 148 & 20 & 64 & 52 \\
\hline Strategic Plan & 13 & 65 & 3 & 21.6 & 20 \\
\hline Environmental Plan/Strategy Report & 15 & 182 & 11 & 56.4 & 44.5 \\
\hline Sustainability Plan/Strategy Report & 17 & 206 & 2 & 63.2 & 56 \\
\hline Official Community Plan & 3 & 202 & 29 & 119.6 & 128 \\
\hline $\begin{array}{l}\text { Corporate Environment, Health and } \\
\text { Safety Report }\end{array}$ & 1 & 28 & 28 & 28 & 28 \\
\hline $\begin{array}{l}\text { Environmental Goals and Sustainability } \\
\text { Report }\end{array}$ & 1 & 60 & 60 & 60 & 60 \\
\hline Community Report & 1 & 12 & 12 & 12 & 12 \\
\hline Sustainable Development Report & 2 & 145 & 4 & $74 / 5$ & 74.5 \\
\hline TOTAL & $\mathbf{6 1}$ & $\mathbf{2 0 6}$ & $\mathbf{3}$ & $\mathbf{5 6 . 4}$ & $\mathbf{4 5}$ \\
\hline
\end{tabular}

*Total equals 61 not 59 as the City of Calgary and City of Oakville produced two reports that met the criteria of the study

Table 10 provides a separate list of the reports titles, lengths and format among Canadian provinces/territories and the federal government, including the year of the most recent reports, length of reports, and report format (PDF/Online). The content analysis revealed that nine out of $14(64 \%)$ of the Canadian jurisdictions produce a comprehensive "whole of government view" sustainability report or SOE report. The three provinces that do not produce such a report are Newfoundland, Nunavut and Ontario. However, all three provinces report monitoring information 
through a number of other mediums and single-issue reports. For instance, Ontario publishes a range of documents that focus on a number of different sustainability topics that are material to the province, such as State of Ontario's Protected Areas Report, State of Ontario's Forests Report, etc. Under the Federal Sustainable Development Act, the Federal Government is required to report on its progress on the Federal Sustainable Development Strategy and this must be done at least once every three years. Furthermore, each province/territory is governed by different legislation that determine the reporting period and requirements of their jurisdiction.

Table 10: List of reports published by provincial and federal government of Canada

\begin{tabular}{|c|c|c|c|c|}
\hline Province/Territory & Report Title & Year & Length & Format \\
\hline Alberta & State of Environment Report & 2015 & & Website \\
\hline British Columbia & Environmental Reporting BC & 2015 & & Website \\
\hline Manitoba & $\begin{array}{l}\text { Provincial Sustainability Report } \\
\text { for Manitoba }\end{array}$ & 2009 & 136 & PDF \\
\hline New Brunswick & $\begin{array}{l}\text { Air, Land and Water: Reporting } \\
\text { to New Brunswickers on } \\
\text { Environmental Progress }\end{array}$ & 2003 & 24 & PDF \\
\hline Newfoundland & No Comprehensive Report & & & \\
\hline Northwest Territories & State of the Environment Report & 2015 & 20 & Website/PDF \\
\hline Nova Scotia & $\begin{array}{l}\text { Environmental Goals and } \\
\text { Sustainability Prosperity Report } \\
\text { (EGSDPA) }\end{array}$ & 2015 & 60 & PDF \\
\hline Nunavut & No Comprehensive Report & & & \\
\hline Ontario & No Comprehensive Report & & & \\
\hline Prince Edward Island & State of Environment Report & 2010 & 66 & PDF \\
\hline Quebec & $\begin{array}{l}\text { Government of Quebec } \\
\text { Sustainable Development } \\
\text { Strategy }\end{array}$ & 2015 & 4 & $\begin{array}{c}\text { PDF/ } \\
\text { Website }\end{array}$ \\
\hline Saskatchewan & State of Environment Report & 2015 & 92 & PDF \\
\hline Yukon & $\begin{array}{l}\text { State of Environment Interim } \\
\text { Report- 2015: Environmental } \\
\text { Indicators }\end{array}$ & 2015 & 44 & $\begin{array}{c}\text { PDF/ } \\
\text { Website }\end{array}$ \\
\hline Canada & $\begin{array}{l}\text { Federal Sustainability } \\
\text { Development Strategy: Progress } \\
\text { Report }\end{array}$ & 2015 & 145 & $\begin{array}{c}\mathrm{PDF} / \\
\text { Website }\end{array}$ \\
\hline
\end{tabular}




\subsection{Report Lengths \\ 5.3.1 Private Sector}

There is a wide range of report lengths in the studied sample. The minimum, maximum, median and mean values were calculated for each private sector report type, summarized in Table 8. These calculations excluded one report, as it was only available online and not in a downloadable PDF format: "IAMGOLDs Health, safety and Sustainability Report". The maximum report length was 202 pages and the minimum report length was 4 pages. Progressive Waste Solutions produced the shortest report. The report resembled more of a sustainability policy rather than a comprehensive sustainability report. The longest report was TransAlta's Integrated Report. Despite the significant variance between shortest and longest report lengths, the mean and median values remain fairly close. The median length was 44 pages, while the mean was 53.6. The common length of sustainability reports, responsibility reports and CSR reports is between 55-65 pages. Other report types did not have an adequate number of reports to draw meaningful conclusions from. Report years ranged from 2013-2015. Two reports were published in 2013, 21 reports from 2014, and 27 reports from 2015.

\subsubsection{Public Sector}

Public sector report lengths varied between report types. The mean value of public sector report lengths is 56.4 and the median value is 45 . These calculations excluded three reports that were only offered as an online website (BC's Environmental Report, Alberta's State of Environment Report and Northwest Territories State of Environment Report). The longest report is 206 pages produced by the City of Markham, titled "Markham's Greenprint Sustainability Plan". This report is also the only report in the sample to follow the Global Reporting Initiative (GRI). The shortest report is a 3-page strategic plan published by Clarington, titled “Clarington's Strategic Plan for 2015-2018. Generally, the average strațegic plan tended to be between 20-30 pages long. 
This is almost half the common length of the sustainability plan/reports and environmental plan/reports, which typically ranged from 50-60 pages.

\subsubsection{Overall Comparison}

The titles and names of the reports varied among and within the private and public sectors. Although the reports varied in formats, content and scope, they were all intended to be the primary document to communicate the organization's sustainability progress. Table 11 outlines the top three report types published for each sector. Both the public and private sectors primarily use a sustainability report/plan to communicate their sustainability endeavors. However, it is important to note an important distinction between the two sectors. Unlike the private sector, public sector sustainability reporting generally does not provide information on how their own performance as an organization impacts the environment and society. This is consistent with the findings from the literature review, that few public sector organizations produce "company-style" sustainability reports. Nevertheless, this type of reporting and monitoring is fundamental to understanding impacts and targeting actions in key areas of sustainability within a defined geographical boundary.

\begin{tabular}{|l|l|}
\hline PRIVATE SECTOR & PUBLIC SECTOR \\
\hline Sustainability Report (53\%) & Sustainability Plan/Strategy Report (27\%) \\
\hline Corporate Social Responsibility Report (14\%) & Environmental Plan/Strategy Report (24\%) \\
\hline Responsibility Report (12\%) & Strategic Plan (21\%) \\
\hline
\end{tabular}

Table 11: Top report types per sector

Despite producing different report types, the median and mean length values for private and public sector reports were fairly close (53.6 and 56.4). The reporting cycles between the two sectors differ. The private sector organizations sampled typically publish a sustainability report on an annual or biannual basis. However, public sector organizations rely heavily on census-based 
data. As a result, reports are generally published on a four-year reporting period. The challenge with this type of reporting is that it does not provide a lot of instant feedback. On the other hand, it allows public sector organizations to outline their long-term vision and sustainability direction. Such an approach is lacking among private sector organizations, with only one organization, Metro Inc., producing a long-term vision plan: "Metro's 2020 Vision".

\subsection{Web-based Sustainability Reporting}

\subsubsection{Private Sector}

Consistent with the findings from the literature, the study revealed that private sector organizations are utilizing web-based tools to enhance the transparency and communication of their sustainability disclosure. Forty-four percent of private sector organizations offered their sustainability reports as a web-based interactive report, along with a downloadable PDF version. Only one organization (IAMGOLD) did not provide the option of a PDF version. The web-based report option makes it easier for readers to navigate through large amounts of data and find the information that is most pertinent to them. This was expressed on Canfor's website, stating "The format makes it easier for readers to identify specific indicators and find the supporting information". Table 12 provides the list of private sector organizations that offered interactive web-based sustainability reports. These organizations belonged to a range of industries across the sample.

Table 12: List of private sector companies that produce online sustainability report Private Sector Organization Industry

Arc Resources Limited

Artis REIT

Bombardier Inc.

Canfor Corporation

Canadian Imperia Bank of Canada (CIBC)

\section{Oil \& Gas}

Financial Services

Engineering and Manufacturing

Forestry \& Paper

Banking

53 


\begin{tabular}{l|l}
\hline Genworth MI Canada & Financial Services \\
\hline Great-West Life & Financial Services \\
\hline Husky Energy Inc. & Energy \\
\hline IAMGOLD Corporation & Mining \\
\hline IGM Financial Inc & Financial Services \\
\hline Imperial Oil Ltd. & Oil \& Gas \\
\hline Innergex Renewable Energy Inc. & Energy \\
\hline Kinross Gold Inc. & Mining \\
\hline KP Tissue Inc. & Consumer Goods/Retailer \\
\hline Loblaws Companies Ltd & Food \& Beverage Retailer \\
\hline Maple Leaf Foods Inc. & Food \& Beverage Retailer \\
\hline Metro & Food \& Beverage Retailer \\
\hline Sherritt International Corporation & Mining \\
\hline Suncor Energy & Oil \& Gas \\
\hline Teck Resources & Mining \\
\hline Telus Corporation & Telecommunications \\
\hline TransCanada Corporation & Oil \& Gas \\
\hline
\end{tabular}

\subsubsection{Public Sector}

Although most public sector organizations continue to publish stand-alone sustainability reports, the study found that some organizations are beginning to leverage web-based reporting as a means to more readily report to the public. The finding suggest that this trend is occurring in the most populous jurisdictions. The City of Edmonton, City of Calgary and City of Waterloo produce performance dashboards, which showcase performance data for a number of selected indicators in an interactive web-based interface. The City of Edmonton stated on its website that "the purpose of the dashboard is to bring together in one place the City's data that otherwise are stored in multiple databases across the entire corporation". The City of Pickering and the City of Edmonton both offer their sustainability report as an online website in addition to a downloadable PDF version. While most public sector organization $\$ 4$ ncluded in the sample did not produce a web- 
based sustainability report, $40 \%$ of participants from the interview portion indicated an interest to do so. This underscores an emerging trend toward web-based reporting among public sector organizations in the near future.

\subsubsection{Overall Comparison}

The study revealed that both the public and private sectors are moving toward online sustainability reporting, however, private sector organizations are much further along this trajectory than the public sector. This trend may be in response to increased pressure from the public for more up-to-date information, as web-based reports can be more easily updated with new information. This may be a direct result of the increased coercive pressure from external stakeholders faced by both sectors to further legitimize their activities, although these pressures are evidently more apparent for private sector organizations.

\subsection{Sustainability Reporting Frameworks and Standards}

\subsubsection{Private Sector}

Based on the content analysis, the most commonly utilized sustainability reporting guideline among private sector organizations is the GRI, with $78 \%$ of the sample referencing it in their sustainability reports. This is consistent with findings from previous studies outlined in the literature review. Fifty-four percent of private sector organizations reported to the Carbon Disclosure Project (CDP), while 38\% of organizations reported to the GHG protocol. Only 4 private sector organizations mentioned the SDGs in either their sustainability report, and/or organizational website. These organizations included Teck Resources, Gold Corp, Telus, and TD Bank. The relatively low number of companies referencing the SDGs is justified given their very recent release. As organizations in the private sector become more familiar with the SDGs, and the 
most appropriate way to apply them to their reporting, this number is likely to increase. A summary of these findings is provided in Table 13 below.

Table 13: Percentage of reporting guidelines/principles referenced by private sector organizations

\begin{tabular}{|l|r|r|}
\hline Reporting Guidelines/Principles & $\begin{array}{l}\text { No. of } \\
\text { Companies }\end{array}$ & $\begin{array}{l}\text { \% of } \\
\text { Companies }\end{array}$ \\
\hline Global Reporting Initiative & 39 & 78 \\
\hline Carbon Disclosure Project & 27 & 54 \\
\hline GHG Protocol & 19 & 38 \\
\hline United Nations Global Compact & 13 & 26 \\
\hline ISO 14001 & 19 & 38 \\
\hline Sustainable Development Goals & 4 & 8 \\
\hline
\end{tabular}

\subsubsection{Public Sector}

The content analysis revealed that organizations in the public sector do not apply a common framework to their sustainability reports. The City of Markham was the only public sector organization in the sample to align its sustainability reporting with the Global Reporting Initiative (GRI). Instead, report content was selected based on feedback from public consultations, workshops, and a review of the existing reporting approaches, frameworks and indicators used in other jurisdictions. For instance, the Province of Saskatchewan indicated in its report that it looked to other jurisdictions, such as "British Columbia, Alberta, Australia, New Zealand and the United States" in the development of its 2015 State of Environment report.

In some cases, public sector organizations drew from other sustainability management tools to shape report content, such as the ISO 14001 standard. For instance, the cities of Edmonton, Richmond Hill, Hamilton, Halifax, Kitchener and Waterloo have all adopted the ISO14001 standard. The content analysis also revealed that there is an upward trend in public organizations voluntarily reporting their greenhouse gas $(\mathrm{GHG})$ emissions to reporting registries, particularly at 
the local level, with $17 \%$ reporting to the Carbonn Climate Registry (cCR). Most public sector organizations are already producing such information in accordance with various regulations. For example, in Ontario, the Green Energy Act (Ontario Regulation 397/11), requires local/regional governments to report their energy use and GHG emissions for facilities annually and publish a report on their website (Government of Ontario, 2016). Thus, reporting GHG information to an initiative such as the cCR requires few additional resources.

It should be noted that while there was no mention of the SDGs in the public sector sample, the federal Government of Canada recently released its latest 2016 report, which largely centered around the SDGs. This report was released after the content analysis for this study was conducted and therefore was not included in the analysis. This highlights the need for future studies to explore the application of SDGs in both the public and private sectors more rigorously as organizations begin to become familiarized with them.

Table 14: Percentage of reporting guidelines/principles referenced by the public sector

\begin{tabular}{|l|r|r|}
\hline Reporting Guidelines/Principles & $\begin{array}{l}\text { No. of } \\
\text { Organizations }\end{array}$ & $\begin{array}{l}\text { \% of } \\
\text { Organizations }\end{array}$ \\
\hline Global Reporting Initiative (GRI) & 1 & 1 \\
\hline ISO 14001 & 5 & 8 \\
\hline Carbonn Climate Registry & 10 & 17 \\
\hline Carbon Disclosure Project (CDP) & 4 & 6 \\
\hline GHG Protocol & 3 & 5 \\
\hline United Nations Global Compact & 0 & 0 \\
\hline Sustainable Development Goals & 0 & 0 \\
\hline
\end{tabular}

\subsubsection{Overall Comparison}

The content analysis revealed that the use of standardized reporting mechanisms is fairly uncommon among the public sector, with only one organization referencing the GRI. On the other 
hand, $78 \%$ of private sector organizations referenced the GRI. The significantly higher number of private sector organizations referencing the GRI and other reporting standards, may be a result of normative pressures exerted on private sector organizations to remain competitive in an increasingly professionalized environment. As public sector organizations operate in generally non-competitive environments, they are not subject to the same pressures. However, the analysis indicates that both sectors are increasingly reporting climate change information to registries such as the $\mathrm{CDP}$ for the private sector, and the $\mathrm{cCR}$ for the public sector. This is likely due to the high public interest around the issues of climate change, and underscores the mounting societal expectations for both government and the private sector to take action.

\subsection{Sustainability Goals and Targets}

The content analysis produced a list of 1,498 goals and targets that met the criteria of the study. The public sector accounted for 1084, while the private sector accounted for 414 of the total goals/targets analyzed. Despite producing far less goals and targets than the public sector, the private sector had more organizations disclosing goals, with $60 \%$ of them doing so, compared to $45 \%$ from the public sector. Furthermore, many of the goals and targets disclosed by the public sector were broad statements. Both public and private sector organizations established goals typically including a range of items in different areas, including those pertaining to water, energy, land use, GHG emissions, economic development at the community level, and more.

\subsubsection{Private Sector}

Among private sector organizations, 213 of the 413 sustainability goals (52 percent) reviewed pertained to specific goals with actionable targets and detailed outcomes. The finding that just over half of all private sector sustainability goals included specific targets suggests private organizations consider the importance of setting specific targets and goals with regard to 
operational and other sustainability goals. Private organizations established goals such as reducing waste, improving workplace health, well-being and safety, and promoting employee engagement. Goals established by private organizations focused on key sustainability issues as well as potential opportunities available to firms. For example, private sector organizations frequently emphasized a need to promote health and safety in the workplace, as well as specific philanthropic actions for the community.

Private organizations were less likely to establish specific metrics and outcomes with respect to goals like stakeholder engagement, with only $4 \%$ of organizations setting specific goals. The less tangible nature of certain goals resulted in private organizations establishing these as soft goals without specific intended outcomes. Specific goals included those such as the need to reduce specific uses of energy and other resources, such as water. Private organizations often sought to note specific impacts of their own activities in goals, and then express how goals would lessen these impacts. For example, one goal included reducing concentrations of major air pollutants produced through mining and other activities that typically occur in Northern Ontario. Goals with hard and clearly defined targets are more meaningful as sustainability goals because they demonstrate that the organization has put more time and effort into the development of these goals, particularly when compared with vague and non-specific goals related to sustainability. While such goals are often designed to reflect particular values and express an organizational commitment to achieving a certain outcome, without means to evaluate progress, they are limited in terms of their potential benefit.

For private sector organizations, the majority of specific goals related to workplace health and safety. Overall, 43 of 213 specific goals (20 percent) related to workplace health and safety. Organizations in the private sector identifying specific workplace health and safety goals included 
mining companies such as Avalon Mining and Barrick Gold, along with Capstone Mining and Aura Minerals. Other organizations such as Bombardier, Cogeco, Maple Leaf Foods, and Loblaws all established similar goals with respect to workplace health and safety. Specific goals included reducing or eliminating the number of workplace accidents in a given period, or the meeting of other specific targets with respect to workplace health and safety. An emphasis on workplace health and safety reflects the need of private organizations to not only ensure compliance with all relevant health and safety legislation, but also the need to protect employees and other stakeholders.

There is also an important financial dimension to establishing workplace health and safety goals for private organizations. Improving workplace health and safety can have significant implications for a company's bottom line. A lack of adherence to appropriate workplace health and safety guidelines can create serious liabilities for an organization, particularly organizations operating in the resource extraction industries. Such sustainability goals are thus important for maintaining an appropriate level of financial performance, protecting key company stakeholders, and insulating the company from potential liabilities related to workplace accidents and other issues. Table 15 lists the top ten goals mentioned most frequently by the private sector. It provides a basic breakdown of the total number of mentions per goal category, the number of goals that were specific, and the percentage of organizations reporting at least one specific goal.

Table 15: Top 10 Goals/Targets Reported by Private Sector Organizations

\begin{tabular}{|l|c|c|c|}
\hline Goal Category & $\begin{array}{l}\text { N. of } \\
\text { mentions }\end{array}$ & $\begin{array}{l}\text { N. of } \\
\text { Specific } \\
\text { goals }\end{array}$ & $\begin{array}{l}\text { \% of Orgs. } \\
\text { reporting } \geq 1 \\
\text { specific goal }\end{array}$ \\
\hline $\begin{array}{l}\text { Workplace Health \& } \\
\text { Safety }\end{array}$ & 56 & 43 & 40 \\
\hline Employee Engagement & 48 & 24 & 26 \\
\hline Philanthropy/Community & 41 & 15 & 16 \\
\hline & 60 & & \\
\hline
\end{tabular}




\begin{tabular}{|l|l|l|l|}
\hline Energy & 30 & 20 & 26 \\
\hline Emissions/Air & 29 & 19 & 28 \\
\hline Employee Diversity & 28 & 15 & 12 \\
\hline Waste & 25 & 17 & 26 \\
\hline Stakeholder Engagement & 21 & 2 & 4 \\
\hline Water & 20 & 7 & 14 \\
\hline Procurement/Supply & 17 & 8 & 14 \\
\hline
\end{tabular}

\subsubsection{Public Sector}

In public sector organizations, 483 of 1084 (45 percent) sustainability goals were detailed and specific, with specific targets included and metrics provided for assessing success. Public organizations established hard sustainability goals in many of the same areas as those established by private sector organizations. For example, like private organizations, public sector organizations emphasized goals with regard to greenhouse gas emissions, water, air, waste, stakeholder engagement, natural heritage, land use, and more. These organizations also set clear goals in areas of arts and culture, customer satisfaction, and community economic development.

A review of public sector organizations shows that they establish a broad and diverse array of sustainability goals in different areas. However, an important distinction to make here is that most of the goals/targets included relate to the external condition of a specific area, and not on the organizations own performance. Goals related to outcomes such as land use typically involve a specific reduction in land used for certain purposes. Conversely, goals related to economic development establish a particular goal related to either jobs or growth in the region. For example, while some public organizations focused on increasing their jobs to labour force ratio, others focused on increasing their region's gross domestic product (GDP). Goals related to buildings and 
infrastructure typically included goals such as increasing the number of sustainable buildings in a given area by a set amount within a specific timeframe.

The most common specific sustainability goal established among public sector organizations related to emissions/air, with 61 of the 483 hard goals related to it, for a total of 12 percent. These goals included both corporate and community wide reduction targets of GHG emissions, and other air pollutants. This is in line with the assumption that organizations are more likely to set specific goals and targets on issues of high public concern. Furthermore, many public sector organizations are required to disclose their energy use and GHG emissions for their facilities annually, and set reduction targets accordingly (Government of Ontario, 2016).

The second most common specific sustainability goal related to transportation and transportation use. 50 of 483 hard goals related directly to transportation, for a total of 10 percent. For public sector organizations, specific transportation goals included things like increasing the use of public transit, decreasing the use of private transit, and promoting more sustainable modes of transport. That public sector organizations focus efforts to establish specific goals on transportation suggest their understanding of the significant impacts associated with transportation. Beyond the direct impacts to the local environment in terms of atmospheric pollution, public organizations, often need to concern themselves with traffic flows, efficiency in transportation, and the successful maintenance of public transit systems. Table 16 lists the top ten goals mentioned most frequently by the public sector.

Table 16: Top 10 Goals/Targets Reported by Public Sector Organizations
\begin{tabular}{|l|c|c|c|}
\hline Goal Category & $\begin{array}{l}\text { N. of } \\
\text { mentions }\end{array}$ & $\begin{array}{l}\text { N. of } \\
\text { Specific } \\
\text { goals }\end{array}$ & $\begin{array}{l}\text { \% of Orgs. } \\
\text { reporting } \geq 1 \\
\text { specific goal }\end{array}$ \\
\hline Emission/Air & 104 & 61 & 16 \\
\hline Water & 91 & 40 & 20 \\
\hline
\end{tabular}




\begin{tabular}{|l|c|c|c|}
\hline Goal Category & $\begin{array}{l}\text { N. of } \\
\text { mentions }\end{array}$ & $\begin{array}{l}\text { N. of } \\
\text { Specific } \\
\text { goals }\end{array}$ & $\begin{array}{c}\text { \% of Orgs. } \\
\text { reporting } \geq \mathbf{1} \\
\text { specific goal }\end{array}$ \\
\hline Community Health \& & 92 & 48 & 15 \\
\hline Safety & 93 & 30 & 18 \\
\hline Land Use & 81 & 50 & 32 \\
\hline Transportation & 62 & 35 & 30 \\
\hline Waste & 51 & 13 & 11 \\
\hline Stakeholder Engagement & 87 & 35 & 16 \\
\hline Community Economic & & & \\
\hline Development & 57 & 30 & 22 \\
\hline Energy & 86 & 36 & 22 \\
\hline Natural Heritage & & & \\
\hline
\end{tabular}

\subsubsection{Overall Comparison}

The content analysis revealed there is some degree of alignment between private and public sector sustainability goals and targets. Private sector organizations have emphasized more the need to establish goals with specific metrics and targets. Such targets make assessment and evaluation possible and promote the potential for goals to garner results. A greater emphasis on specific goals which can be evaluated may reflect the need for private sector organizations to be more responsive to the needs of their stakeholders, particularly with regard to financial metrics and production outcomes.

At the same time, even among private sector organizations, only 52 percent of all sustainability goals are established with clear goals and metrics for evaluation in mind. This means that almost half of private sector goals are not quantified and cannot be meaningfully evaluated. At the same time, it must be noted that the problem is even worse in the public sector. The majority of sustainability goals established by public sector organizations are vague and non-specific. This 
has significant implications for the ability of these organizations to accomplish their stated important sustainability goals. Without clear objectives or targets, goals are unlikely to promote more sustainable activities in operation, as well as promote goodwill among certain stakeholders. Indeed, non-specific goals can do little to help the organization reach a specific target in terms of making improvements in a given area.

While public sector organizations emphasize the need to improve sustainability in areas such as emissions/air, water and transportation, private sector organizations place a stronger focus on upholding goals related directly to their employees. This reflects the importance of these different activities for these respective types of organizations. For instance, public sector organizations need to increasingly respond to the various transportation needs of those in their communities, but at the same time address the complex environmental and social impacts stemming from the use of transportation systems. Conversely, private sector organizations have a special impetus to promote improved workplace health and safety as a means of both protecting key stakeholders, as well as demonstrating accountability to others. Improved efforts in both of these areas can reduce the potential liabilities facing these organizations, as well as lead to a variety of other positive outcomes. The goals and activities aimed at improving sustainability are thus best understood as reflective of the individual organization's specific focus and their interests.

\subsection{Public and Private Sector References to Each Other}

The content analysis revealed that public and private sector organizations are making reference to each other in their sustainability reports and/or websites in mainly three broad categories: public-private and community-based partnerships, enabling actions by government, and advancing public policy. Table 15 provides a summary of representative quotes from the content analysis of the organizations included in the sample. 
Table 17: List of representative quotes from public and private sector sustainability reports and/or websites that reference each other

\begin{tabular}{ll}
\hline Category & \\
\hline Public- & Importance of \\
Private and & partnerships \\
Community- & \\
based & \\
Partnerships &
\end{tabular}

Representative References

"We acknowledge that we cannot achieve sustainable

development alone-partners such as provinces and territories, Indigenous Peoples, communities, businesses, scientists, and non-governmental organizations all play a role in helping us meet our objectives." (Federal Government of Canada)

"Partner with non-governmental organizations, business and other levels of government to access or develop tools that strategically enhance the technical and social capacity of individuals and organizations interested in enhancing Winnipeg's sustainability. These enhancements could be in areas such as sustainable procurement, local food opportunities, addressing poverty, literacy, green energy, education and awareness, sustainable design, water and energy efficiency." (City of Winnipeg)

"Governments alone can't solve today's environmental challenges, nor can industries or institutions. Improving the environmental health of our community requires the involvement of everyone - residents, workers, business owners, organizations, schools, colleges, universities and others. - (Greater Sudbury Sustainable Action Plan, 2010)" "Coordinated direction and efforts of organizations - public, private and non-profit - will lead to positive environmental results and commitment at local, national and international level." (City of Ottawa)

"We will build partnerships with governments, academia, social profit organizations and industry to increase our collective impact." (Maple Lead Foods)

"Other than oil and gas, there is no other industry that is capable of generating the wealth needed to support a

Funding Partnerships growing economy and generate the revenues needed to fund government services." (Avalon Mining)

"We facilitate the funding of public infrastructure, including schools, health- care facilities and cultural institutions, all of which contribute to general social well-being." (BMO)

"We also work with governments to leverage funding to implement sustainability projects, especially those that combat climate change." (KP Tissue)

"Seeking opportunities, where possible, to creatively finance initiatives with the assistance of public-private partnerships." (City of Cambridge) 


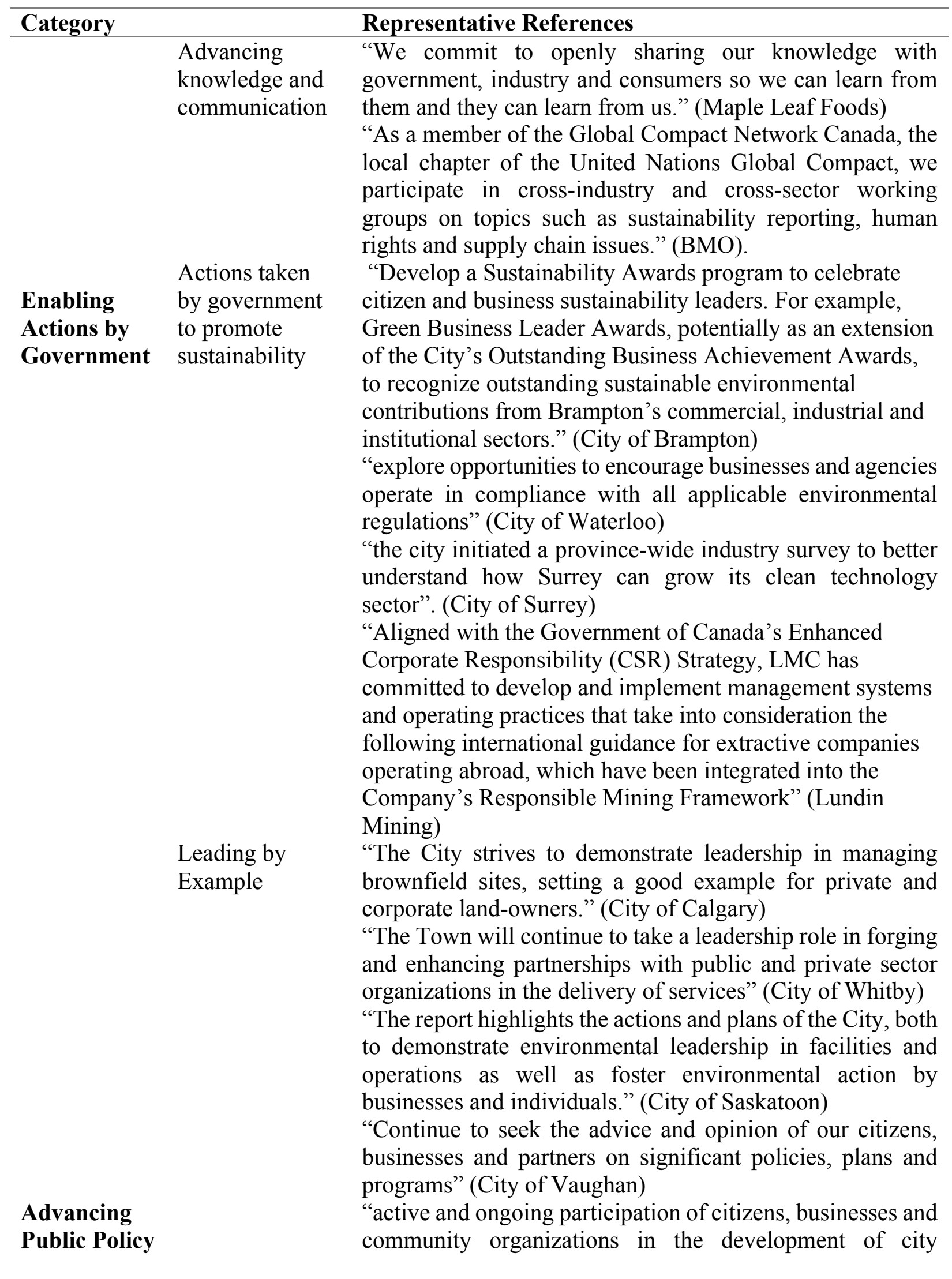




\begin{tabular}{ll}
\hline Category & Representative References \\
\hline policies, strategies and plans for strategic investments." \\
(City of Kitchener) \\
"We believe that we can make a contribution to the \\
development of sound public policy by providing accurate \\
information on our mining activities. We participate in \\
government outreach related to the mining industry...we \\
initiated the Ontario Mining Roundtable, a unique gathering \\
of approximately 90 leaders, including cabinet ministers, \\
chief executive officers, banking executives, First Nations \\
leaders, experts from the mining industry, mining capital \\
markets, the Government of Ontario, and associated supply \\
and service industries in order to discuss Ontario's mining \\
and related industries from an innovative perspective." \\
(Gold Corporation) \\
"Our Government Affairs team guides Teck's approach to \\
public policy and engages government directly through a \\
variety of means, including written advocacy letters and \\
submissions, roundtable meetings, and one-on-one \\
meetings. Teck also engages with government indirectly \\
through our business and industry associations. Teck \\
regularly evaluates the effectiveness of our public policy \\
engagement by identifying where our advocacy has resulted \\
in outcomes that support our business objectives." (Teck \\
Resources)
\end{tabular}

\subsubsection{Public-Private and Community-Based Partnerships}

Many of the references made in both public and private sector reports focused on the need for collaboration between the public and private sector to facilitate an approach truly capable of addressing sustainability. Different stakeholders, including those in private sector organizations, public sector organizations, and the public at large are needed if efforts to promote sustainability are to be successful. For instance, the City of Vancouver stated in its report: "Our ability to achieve the Green Economy targets will be largely dependent on partnerships with other organizations particularly businesses, social enterprises, and educational institutions."

Public sector organizations especially saw public-private partnerships as important for success with regard to sustainability, with $98 \%$ stating it as an important area of focus. As part of 
eliciting this support from the public, promoting public education and awareness is seen as key. St. Catharine's noted in their report that "real change only occurs when individual residents, businesses and community groups are prepared to make informed choices about the future of the community. The City can play a role in this process, emphasizing dialogue that is meaningful, engaging, and where appropriate, enjoyable". Some public sector reports made reference to specific areas where collaboration between various stakeholders should be leveraged. For instance, the City of Winnipeg listed potential areas for collaboration, such as "sustainable procurement, local food opportunities, addressing poverty, literacy, green energy, education and awareness, sustainable design, water and energy efficiency."

Other references focused on the potential sustainability benefits that can arise with greater collaboration, partnership, and support. For instance, the City of Ottawa noted in its report, "Coordinated direction and efforts of organizations - public, private and non-profit - will lead to positive environmental results and commitment at the local, national and international level." The City of Kingston specifically noted in their report the important role the community can play in the process of spearheading initiatives and promoting the idea of collaborative partnerships: "a community-built/community-owned plan would better inspire sustainability plans and actions within community organizations, institutions, businesses, associations and individuals as well as the municipality". Public-private partnerships were also identified in reports as a successful creative strategy for addressing some of the challenges with regard to funding and other support for sustainability projects. For instance, Oshawa indicated the advantage of "pursuing public and private sector funding partnerships" in order to reach their strategic goals.

Similarly, when discussing the public sector, most references made by the private sector were in regards to the various funding initiatives and donations supplied to the government and 
other public sector agencies. For instance, BMO wrote in its report, "We facilitate the funding of public infrastructure, including schools, health- care facilities and cultural institutions, all of which contribute to general social well-being." The private sector reports generally oriented towards an acceptance and understanding of their role in providing such investments. For instance, a quote from BMO highlighted such a partnership:

"We facilitate the funding of public infrastructure, including schools, health- care facilities and cultural institutions, all of which contribute to general social well-being." (BMO)

Private sector organizations also identified public-private partnerships as an important area for advancing sustainable development. Collaboration with the government and other private sector entities was noted as potentially important for successful sustainability initiatives. Loblaws, a corporation in the Food and Retail sector, noted in its report, "By collaborating with industry peers, governments, academia and non-governmental organizations, we aim to make a positive, sustainable impact". Consulting with the communities and governments where operations are present were also noted as key for developing practical and meaningful sustainability initiatives and projects:

"As partners with our host governments, we may work on issues identified as urgent public policy concerns within local and national jurisdictions. For example, in Nevada, where education is high on the public agenda, we are playing a meaningful role by supporting programs aimed at improving the delivery of education and ensuring children stay in school." (Barrick Gold)

While references conceived of collaboration and partnerships in different ways, a common theme was that sustainability fundamentally requires mutual cooperation and collaboration. The public, the business community, and government all have important roles to play in the shared work of promoting sustainability. 


\subsubsection{Enabling Actions by Government}

Many of the references focused directly on the actions taken by governments to facilitate improved sustainability practices by businesses. In Toronto, the city's partnership with Metrolinx was cited as allowing them to bring programs like Smart Commute, which encourages businesses to promote sustainable travel and commuting among employees. In Prince Edward Island, the province has prioritized a need to "encourage industry to employ best practices to reduce energy use and production of greenhouse gases". Similarly, Burnaby developed an online initiative called Pledge for a Sustainability Community, an online initiative that helps businesses reduce their environmental footprint. Since its launch in 2014, the initiative has garnered over 120 members. Toronto has developed the Live Green Toronto Program, designed to help residents and businesses take simple actions to promote sustainability.

Several reports also made note of the need for local and municipal governments to improve service delivery as a means of reducing the barriers involved in helping business operate more sustainably. In Kingston, it was noted that "the city will build an 'open for business' culture and enhance service by streamlining the development process". This response reflects the perception that public sector organizations need to create the conditions necessary to allow businesses to operate in more sustainable ways. Similarly, London noted the city's need to "support small businesses by improving City processes". These responses frame government, particularly at the local level, as having the potential to facilitate much of the actions needed to promote sustainability through their approach to service delivery as well as the policies and systems introduced and supported. Being "open for business" was also cited as important in responses from Barrie and St. Catharine's, illustrating a perceived connection between supporting business activities and enabling initiatives aimed at promoting sustainability. Reducing the barriers for business in terms 
of their being able to operate in the local community is seen as important for promoting more sustainable outcomes in business. Similarly, Guelph's report indicated that it is government's role to help bring together diverse stakeholders with different needs.

Other references similarly focused on the need to promote education and educational resources to help promote awareness among both the public, as well as the business community. For instance, the City of Brampton noted in its report the need to "educate major business leaders on energy conservation techniques." Because the environment and sustainability are issues that affect all stakeholders in society, shared participation is fundamentally required for success. Beyond education and awareness initiatives, efforts to incentivize and reward those for certain sustainability initiatives was seen as a sound strategy according to many of the public sector references.

In many public sector reports, the need for there to be incentives to help encourage certain sustainability actions, as well as for orienting businesses toward key sustainability issues was evident. For instance, the City of Brampton developed a Sustainability Awards program to highlight the contributions made by local commercial, industrial and institutional sectors. Therefore, efforts to incentivize and reward those for certain sustainability initiatives was seen as a sound strategy. Developing systems and processes to incentivize business as well as reduce the barriers they face toward undertaking more sustainable initiatives and actions in their work should be prioritized.

Other references reflected the need for investigative efforts to understand the kinds of incentives required for promoting sustainability. In Surrey, it was noted that "the city initiated a province-wide industry survey to better understand how Surrey can grow its clean technology sector". Other cities have reported taking similar steps. A response from Calgary noted that the 
city had implemented a corporate-wide online reporting system in 2015 for assessing safety data and facilitating improved decision making. In Oakville, monitoring of annual environmentallythemed public outreach events is seen as important for assessing the efforts made by the city and for identifying potential opportunities where the city can work with residents and businesses to promote sustainability through specific initiatives. Assessment and monitoring efforts are framed as important for orienting the work of local stakeholders and identifying key challenges and barriers to sustainability.

Finally, other references noted the potential for the public sector to serve as an example to the private sector. A response from Calgary noted that "The City strives to demonstrate leadership in managing brownfield sites, setting a good example for private and corporate land-owners". In promoting best practices of sensitive and vulnerable ecological sites, municipal government takes on a leadership role in demonstrating to other stakeholders what effective and successful sustainable management looks like. The private sector similarly looks to the regulations and policies established by government to understand their obligations. For instance, EnCana noted in its report "By continuing to stay engaged in the debate on the most appropriate means to regulate GHG emissions, we gain useful knowledge that allows us to explore different strategies for managing our own emissions and cost". In one sustainability report by Innergex Renewable Energy Inc., they reported a commitment to align their business activities with government objectives. In a similar vein, Lundin Mining Corporation stated:

"Aligned with the Government of Canada's Enhanced Corporate Responsibility (CSR) Strategy, LMC has committed to develop and implement management systems and operating practices that take into consideration the following international guidance for extractive companies operating abroad, which have been integrated into the Company's Responsible Mining Framework" 
In addition, some of the reports noted the need for private sector companies to be informed and consulted about regulatory changes and developments. In some cases, private sector entities noted going beyond regulations to conform to industry best practices and exceed expectations regarding sustainability and related concerns. Nevertheless, it is evident that from both the perspectives of private and public sector entities, government is seen as playing a potentially important role here in terms of encouraging the kind of actions and management desired among businesses.

\subsubsection{Advancing Public Policy}

Being able to participate in the development of public policy was a common theme in private sector reports and websites. The content analysis revealed that $48 \%$ of the sampled companies made a direct statement about the company's position on public policy. Indeed, improved policy was seen as critical from the perspective of private sector respondents, who posited improved policy as a precursor for improved sustainability. For instance, Loblaws stated in its report: "The solution requires thoughtful, stable, harmonized public policy, which enables the private sector and citizens to mobilize." Private sector organizations also identified themselves as important agents in providing their expertise and knowledge to developing sound government policy. Many private sector organizations specifically referenced in their reports the need for "consultation" with different stakeholders with the goal of advancing best practices with regard to sustainability. However, the level of detail on the specific actions undertaken by organizations in advancing public policy was relatively broad. One exception was Gold Corporation, which under the heading "Public Policy Advocacy," stated the following:

"We believe that we can make a contribution to the development of sound public policy by providing accurate information on our mining activities. We participate in government outreach related to the mining industry...we initiated the Ontario Mining Roundtable, a unique gathering of approximately 90 leaders, including cabinet ministers, chief 
executive officers, banking executives, First Nations leaders, experts from the mining industry, mining capital markets, the Government of Ontario, and associated supply and service industries in order to discuss Ontario's mining and related industries from an innovative perspective."

Teck Resources also provided a description of how its organization specifically communicates with government across a number of different public policy issues relevant to their business objectives:

"Our Government Affairs team guides Teck's approach to public policy and engages government directly through a variety of means, including written advocacy letters and submissions, roundtable meetings, and one-on-one meetings. Teck also engages with government indirectly through our business and industry associations. Teck regularly evaluates the effectiveness of our public policy engagement by identifying where our advocacy has resulted in outcomes that support our business objectives."

Some reports stated the importance for government to take into consideration their viewpoint in the development of relevant public policy issues. Nova Scotia, in its sustainability report, outlined the steps it was taking to ensure that various stakeholders were represented in the public policy discussion. For instance, the province implemented a "What We Heard" initiative, stating: "ongoing engagement with municipal and business stakeholders continue to inform development of proposed regulatory amendments." CIBC, a corporation in the Financial sector, outlined in their report: "dialogue and information exchange with government, regulators and policy makers led to changes in regulation, as well as in product development, strategy, and business." Therefore, the content analysis revealed that the need for positive and appropriate relationships with government to influence improved public policy was emphasized by both sectors.

\subsection{Interview Results}

This section presents the results from the semi-structured interviews. The responses from participants are divided into seven main sub-headings. The sub-headings are as follows: defining 
sustainability, motivators/drivers of sustainability reporting, appraisal of performance, current dialogue, benefits of linking reporting, challenges and barriers of linking reporting, and linking reporting through the SDGs. Table 16 provides a summary chart of the representative responses under each of the main sub-headings. Further discussions on the sub-headings are provided below.

Table 18: List of representative quotes from interviews

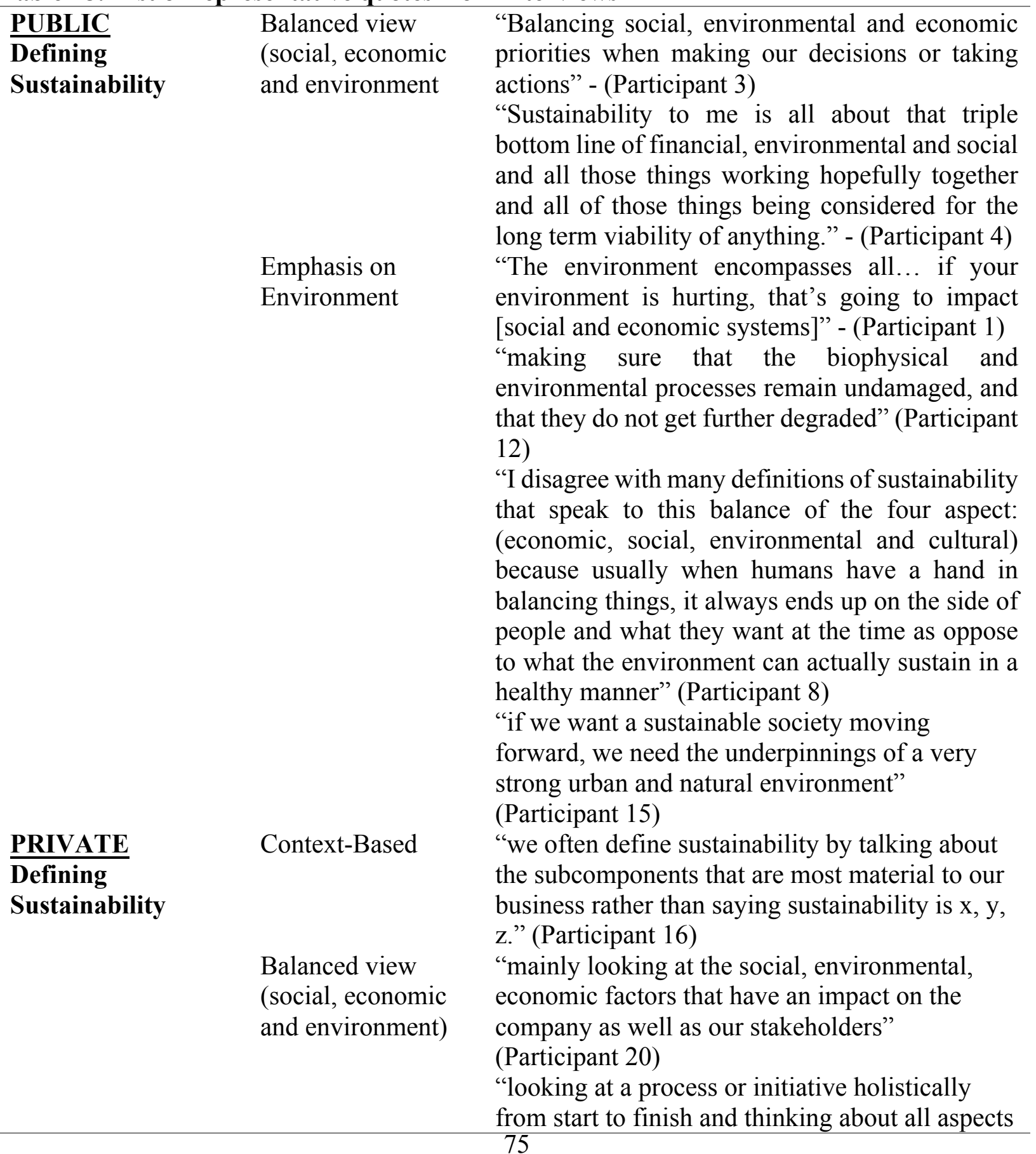




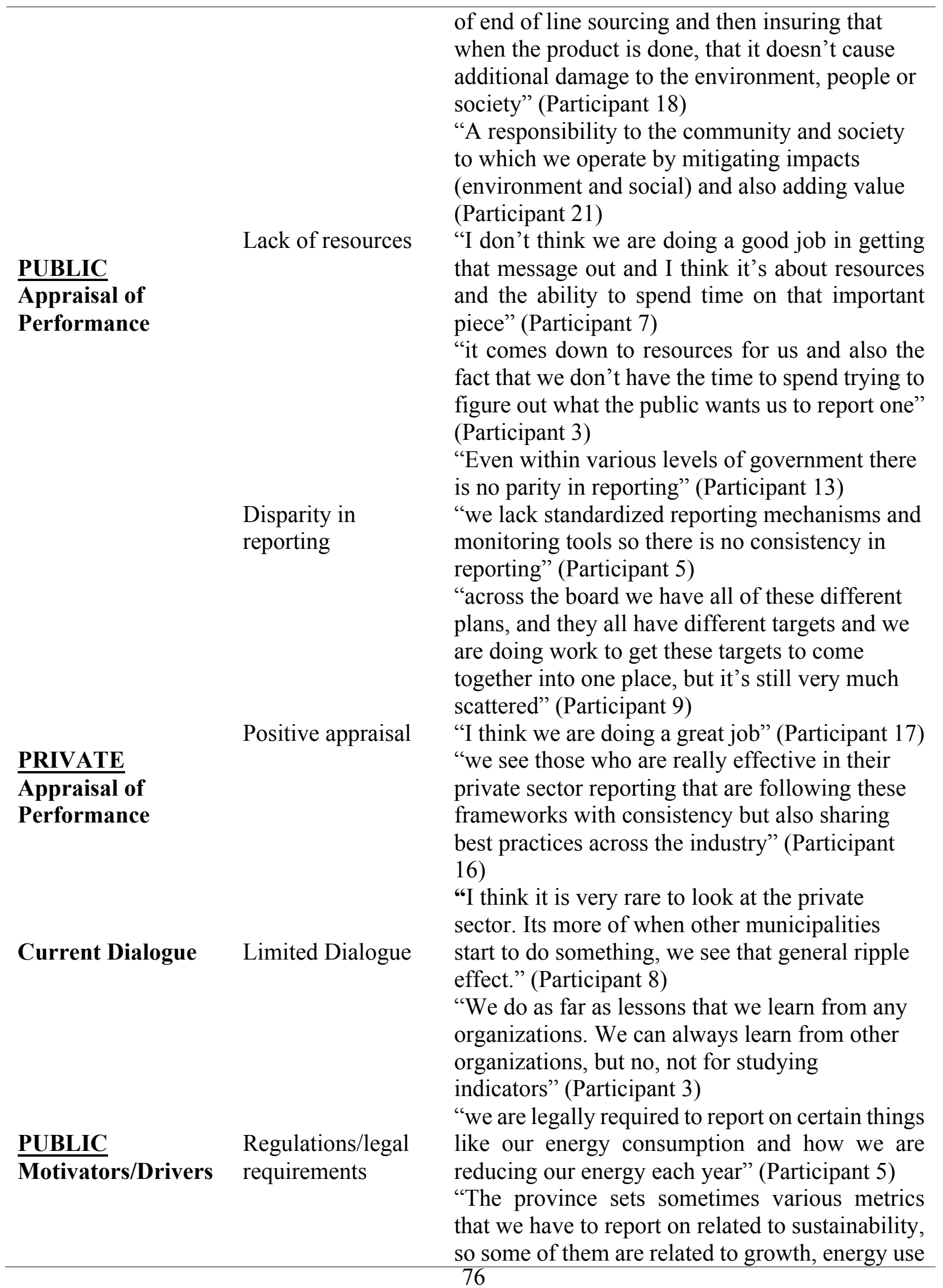




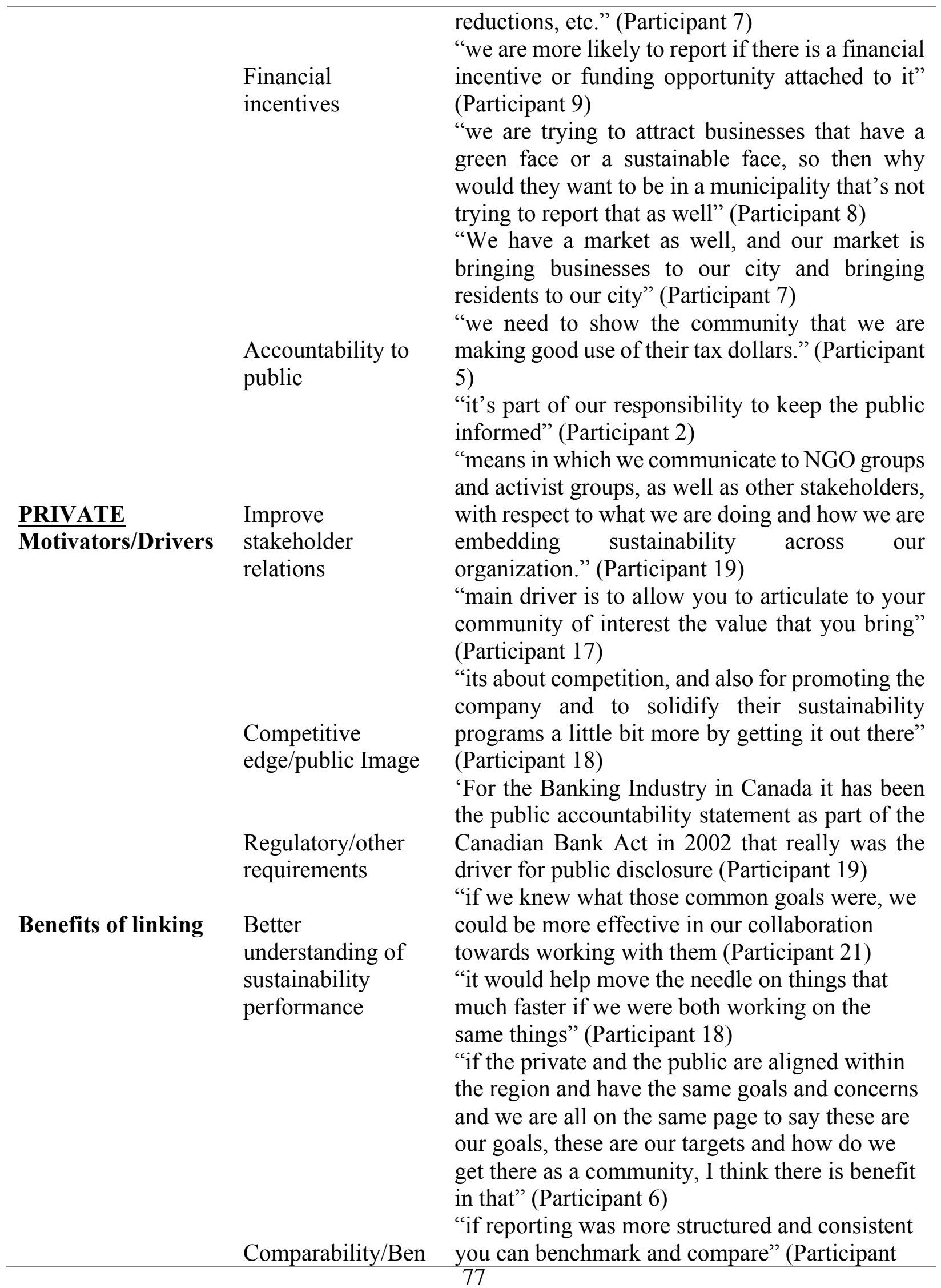




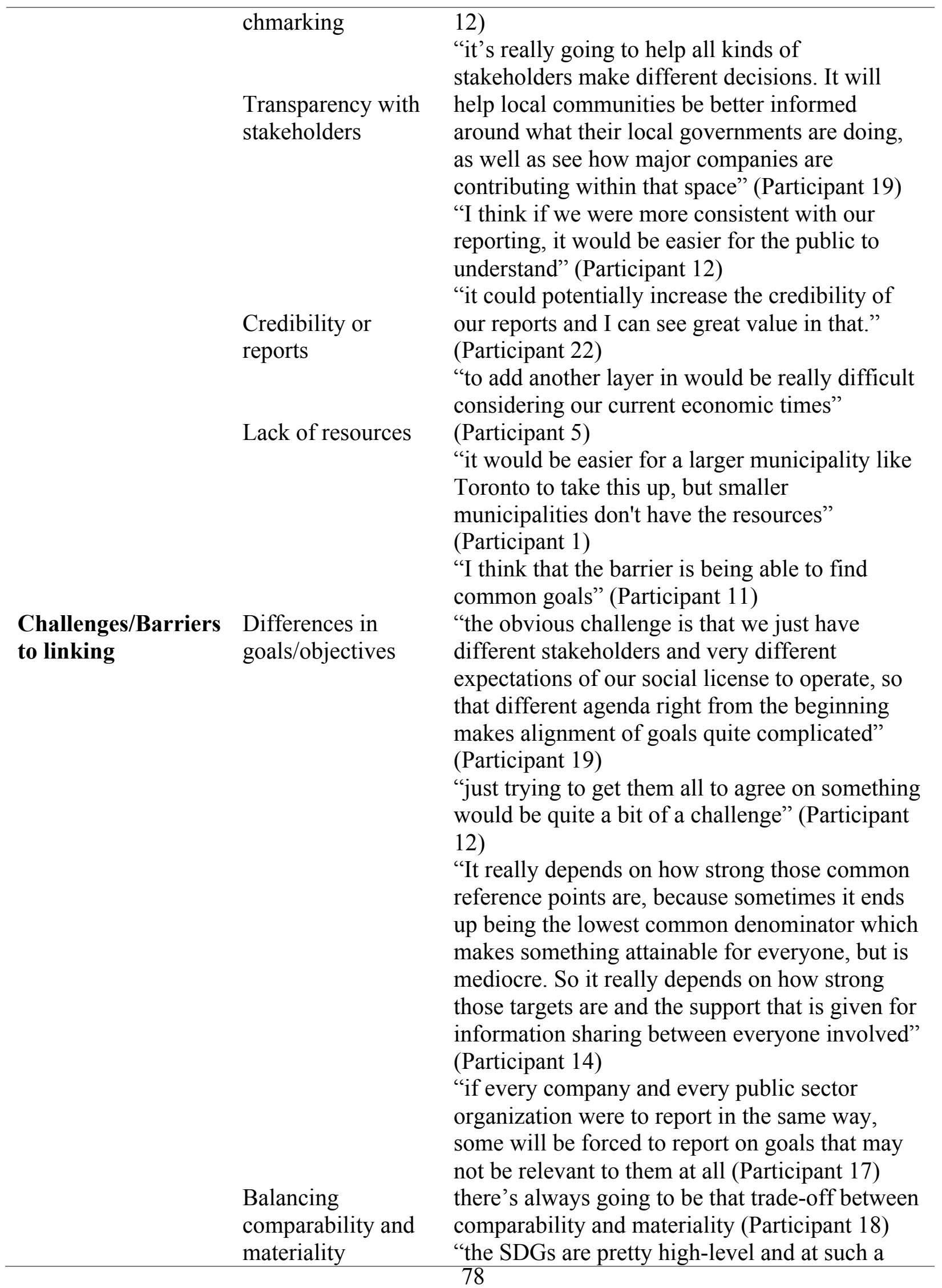




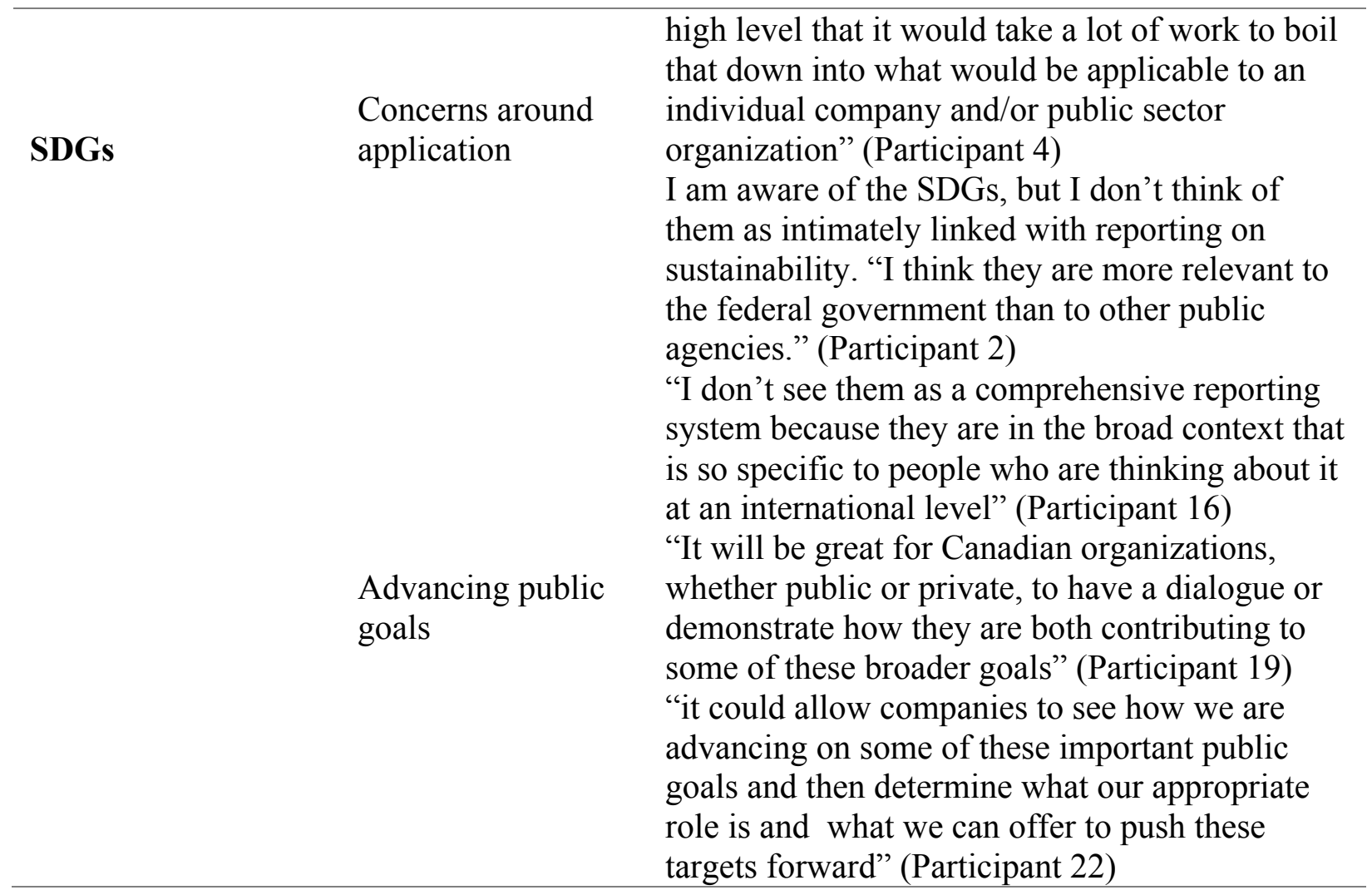

\subsubsection{Defining Sustainability}

The interviews show that public sector organizations tend to define sustainability in terms of the vast systems and different factors involved. Table 16 provides a summary of the definitions outlined by public and private sector respondents. As Table 16 illustrates, for some respondents, sustainability is conceptualized as an ideal involving the social, economic, and cultural. For others, sustainability is mostly about our impact on the environment; overall, public sector organizations see sustainability as a goal in operations. From this perspective, sustainability involves consideration and understanding of how balance can be achieved between meeting our needs and doing so in a way that does not negatively impact environmental, social or cultural systems. At the same time, many members of the public sector organizations interviewed noted that sustainability requires consideration of these different factors that are related, but environmental concerns were 
paramount. Participant 1 explained, "the environment encompasses all... if your environment is hurting, that's going to impact [social and economic systems]". Other participants from the public sector (Participants 8,9,10,12) excluded social and economic aspects of sustainability completely. For instance, participant 12 referred to sustainability as about "making sure that the biophysical and environmental processes remain undamaged."

Conversely, respondents in private organizations tended to think about sustainability in terms of the various impacts associated with their line of business. For instance, participant 16 stated "we often define sustainability by talking about the subcomponents that are most material to our business, rather than saying sustainability is $x, y, z . "$ The participant went on to say their business approached sustainability by assessing and monitoring effects in six areas. The respondent explained, "our 6 focus areas are our people, community, biodiversity water, climate change, energy and air". Thus, respondents from both private and public sector organizations related sustainability specifically to environmental and social impacts. At the same time, respondents from private organizations tended to focus more on bottom-line considerations, in terms of both the economic and reputational benefits associated with reporting.

These findings suggest that even in cases where there exists overlap in terms of the approach taken to sustainability, these organizations are likely to have a different focus and set of priorities. Thereby, coordination must come through efforts aimed first at developing shared and mutual definitions and conceptualizations.

\subsubsection{Motivators/Drivers of Sustainability Reporting}

Table 16 provides a summary of the different motivators for sustainability reporting listed by participants. For both private and public sector organizations, reporting on sustainability was often constructed as an important responsibility to other stakeholders affected by operations. 
Participant 21 explained, "for the private sector, we report because we have obligations through various industries that we are associated with". Indeed, respondents from private organizations routinely noted the need for reporting to both satisfy different stakeholders, as well as to promote a healthy bottom line. Private sector interviewees unanimously bolstered that sustainability reporting was a key mechanism used to solidify their sustainability programs, gain a competitive edge and maintain a positive public image. For instance, participant 19 stated "the CSR report becomes the means in which we communicate to NGO groups and activist groups, as well as other stakeholders, with respect to what we are doing and how we are embedding sustainability across our organization" (Participant 19). Sustainability reporting was not described as voluntary; rather, it was often defined as a critical business process for any firm, regardless of their particular industry or sector of operation.

Conversely, for many of those in public sector organizations, reporting on sustainability was seen as critical for meeting necessary regulatory and other obligations. Participant 10 reminded the interviewer that in many cases, the province or another government body will establish various metrics for public organizations to utilize in their sustainability reporting. Two public sector respondents (Participant 13 and 14) noted that while engaging in sustainability reporting was good and justifiable, they were more likely to pursue it if financial incentives were attached. In this regard, reporting was done to secure various government grants and/or other financial incentives. A related financial motive for some public sector representatives was that sustainability reporting was a vital step in attracting "green" business investment to their jurisdiction.

"we are trying to attract businesses that have a so-called "green" face...so in order to do that, we need to demonstrate that we [are an organization that] also has a sustainability focus" (Participant 8) 
However, the general mandate of public sector organizations to serve their communities appears to orient the members of these organizations toward sustainability reporting as a means of improving quality of life for all citizens (10 out of 15 respondents stated this). Participant 5 provided a representative example:

"we need to show the community that we are making good use of their tax dollars...that we are trying to make our community a wonderful place to live, work and play" (Participant 5)

Nevertheless, both types of organizations may report because they are obliged to, but while the private sector tends to see sustainability reporting as good for a company's bottom-line, public sector organizations see it as being good for the community.

\subsubsection{Appraisal of Performance}

Most of the respondents working in public sector organizations noted that their organizations were not doing enough to effectively disclose sustainability related information to the public (11 out of 15 respondents). Indeed, for many of the respondents in public sector organizations, key challenges associated with successful reporting included a perceived lack of resources. Participant 7 noted "I don't think we are doing a good job in getting that message out and I think it's about resources and the ability to spend time on that important piece".

Similarly, some respondents from the private sector noted that while they had sought to promote sustainability through a variety of processes and systems, more could be done to ensure companies were operating in sustainable ways. However, other respondents noted that their organization was doing a great job in terms of both reporting and living up to its commitment to adhering to key regulations. Respondents from private firms tended to be more pleased with performance in this area than those from public sector organizations. 


\subsubsection{Current Dialogue}

The interviews revealed that both private and public sectors are not heavily influenced by each other when deciding on what to include in their sustainability reports. Instead, the majority of public sector representatives expressed that they were more likely to reference the sustainability practices of other public organizations of similar size and position. When public sector organizations did look to the private sector, it was to determine best practices and innovations. Participant 13 indicated "our group regularly looks to the private sector for best practices, whatever we can use as a way of inspiring us and hopefully developing some innovations, because governments aren't always as innovative as they should be and I think that is where the private sector can influence us". All private sector organizations indicated that they did not look to the public sector for guidance on what to report, outside of recognizing them as a key stakeholder:

"I never look at their reporting. If anything, we try to promote to them what we are talking about, as oppose to the other way around". (Participant 18)

"I think the private sector is really leading the sustainability agenda, and its not the public sector that is doing it...so we aren't really looking at how they are reporting." (Participant 22)

"Honestly, I don't think that there has been a whole lot of that going on here in Canada. I've seen more of that in the UK, where public sector reporting seems to be much more influential." (Participant 19)

"Only as far as they are really just an incredibly important stakeholder, so they would have certainly some influence over our materiality assessment, but not really in terms of specifically how they are reporting" (Participant 17)

Although the interviews revealed a currently low level of dialogue between the sectors, participants from both sectors did express interest in starting this conversation. Participant 19 stated the importance of "greater civic dialogue between the two". Participant 18 stated "I have never had a conversation with government about how we can work together, so I guess the first step would be initiating a conversation and then going from there." 


\subsubsection{Benefits of Linking Reporting}

In terms of the advantages of linking goals and targets, some of the respondents from public sector firms noted that cooperative efforts could provide more significant benefits to the community as a whole. If public and private organizations can work together on specific issues and projects relevant to their communities, they can potentially do more to address a range of sustainability issues and problems. Moreover, with linked goals and targets, specific issues could be prioritized, allowing sustainability efforts to potentially address pressing issues and problems. Participant 1 articulated this by stating "if public and private sector reporting were more closely aligned, it would help determine what problems or issues are being addressed effectively and which ones are not being addressed, or getting worse over time”. Greater alignment and linking was also posited as having a benefit for education; with linked goals and targets, organizations could more clearly understand the relation between certain sustainability issues and overall performance:

"we would have a better picture of what is happening out there, where resources are needed, where information and awareness is needed, mentorship is required... those kinds of things. And it helps in terms of growing this continual corporate conscience of how are we doing as a community." (Participant 15)

Respondents from the private sector cited improved transparency with stakeholders as a major advantage for fostering linkages between the sectors. Participant 16 provided a representative statement:

"I think it's a firm yes. Whenever we can look at a very diverse set of sustainability data in a consistent way, it's really going to help all kinds of stakeholders make different decisions. It will help local communities to be better informed around what their local governments are doing, as well as see how major companies are contributing within that space." (Participant 16) 
Respondents across both sectors agreed that greater linkages in reporting could foster a stronger public-private sector partnership, highlighting areas for increased collaboration, as well as the harmonization of data:

"if we knew what those common goals were, we could be more effective in our collaboration towards working with them...I think for the public and private sector, having consistency around how we evaluate, for example ecosystem services, it is going to be really productive for us moving forward" (Participant 21)

Because private sector firms need to maintain profitability and promote a good reputation with all of their stakeholders, being tied to the government could provide an opportunity for increased credibility of their reports. One participant, (participant 22), stated "it could potentially increase the credibility of our reports and I can see great value in that."

\subsubsection{Challenges and Barriers of Linking Reporting}

Across the public sector, many of the respondents interviewed noted that securing the necessary resources to link goals and targets in reporting was a major challenge. Indeed, problems with regard to the availability of resources were routinely cited as major concerns among those working in public sector organizations, especially for smaller cities. Participant 4 noted that coming up with such resources may not be a problem for a major city such as Toronto, but would be prohibitively difficult for a smaller city or community with less resources.

At the same time, the additional work created by coordination of sustainability systems was highlighted as a key challenge. Some respondents in public sector organizations were doubtful that many private firms would even want to seek partnerships with municipalities or other public sector organizations. In addition, many respondents astutely noted the challenges involved in getting public and private sector organizations to agree on particular goals and targets with respect to sustainability: 
"the oblivious challenge is that we just have different stakeholders and very different expectations of our social license to operate, so that different agenda right from the beginning makes alignment of goals quite complicated. It's not to say that dialogue wouldn't be helpful, I just don't see how public and private sectors could agree on the same goals." (Participant 22)

Most participants in the study were of the view that linking reporting would involve a tradeoff whereby comparability went against materiality (17 out of 22 respondents):

"the challenge would be that if every company and every public sector organization were to report in the same way, some will be forced to report on goals that may not be relevant to them at all, and then you get this cycle of reporting for the sake of reporting. Yes, this would mean more comparability, but it also could mean reporting something that has no meaning for you or meaning for your stakeholders. (Participant 17)

"While you can definitely argue for standardization between the two sectors, what is considered material topics for a jurisdiction as oppose to a company really depends on what their context is. My suggestion is for similar vernaculars, so if we do have the same goal, we are talking about them in the same way, we are using the same measurement, we are clear on what the activities are and then we can look for opportunities to collaborate" (Participant 16)

Despite these apprehensions, there was still a common desire among participants for improved transparency and harmonization of data in sustainability reporting between the two sectors.

\subsubsection{Linking Reporting through the SDGs}

Alignment of targets can potentially be achieved by using a slow and gradual process of coordination. Participant 17 from the mining industry noted that using the SDGs would be helpful, but noted that they should be implemented in a slow and gradual fashion. By focusing on just two or three specific areas at first, alignment of targets between public and private organizations could be more readily achieved. Moreover, the limited knowledge of SDGs among many of the respondents in public sector organizations suggests that a gradual approach to their implementation would be ideal. 
Most respondents from public sector organizations had no prior awareness of the Sustainable Development Goals as advanced by the United Nations, while others had some limited knowledge regarding their scope and makeup. For those respondents who were knowledgeable of SDGs, they were seen as being a viable tool for helping to promote alignment. Even among respondents with limited knowledge of the SDGs, specifically, there was recognition that some framework was needed to bridge the gap between firms in the private and public sectors. At the same time, public sector respondents expressed doubts regarding the applicability of such a highlevel policy framework to the individual organization or jurisdiction. Participant 4 provided a representative response:

"the SDGs are pretty high-level and at such a high level, it would take a lot of work to boil that down into what would be applicable to an individual company and/or public sector organization, and creating those linkages. I think there is a chance that it could be done, but it would take a lot of work." (Participant 4)

One respondent (participant 2) felt that there was little connection between the SDGs and sustainability reporting at all, stating "I am aware of the SDGs, but I don't think of them as intimately linked with reporting on sustainability".

Members of the private organizations were more knowledgeable of the SDGs and more likely to see the SDGs as a viable tool for promoting alignment in reporting. Participant 19 stated "It will be great for Canadian organizations, whether public or private, to have a dialogue or demonstrate how they are both contributing to some of these broader goals". Many of the respondents from mining companies interviewed for this research noted that SDGs or similar tools were already used to a certain extent in guiding their own sustainability reporting. In commenting on the SDGs, participant 17 also noted that "they are a really good communication tool if absolutely nothing else". Participant 19 indicated that they were looking to the federal government for additional guidance on the SDGs, stating "I think Canada is trying to figure out if they should 
look at just a few of them, or try and enact all of them, so it's the same question for companies, just from a different perspective."

Because the use of these metrics helps organizations to capture a wide breadth of information related to their sustainability overall, they are invaluable for informing decisionmaking. These findings suggest that more may need to be done in terms of educating those in public sectors about the SDGs, as well as how they can specifically contribute to improved alignment in sustainability reporting.

\subsection{Summary of Key Findings}

This section provides an overview of the key findings derived from the study as they relate to the four research questions.

\subsubsection{What are the similarities and differences of sustainability reporting between the public and private sector?}

A review of the findings indicates that both the public and private sectors have made some effort on reporting and monitoring their progress against specific sustainability goals and targets. For the public sector, sustainability disclosure is done inconsistently and presented through a range of different reports. These reports typically do not provide information on the organizations own sustainability performance. Instead, public sector reports tend to focus on general policy goals. In this regard, reporting in the public sector fails to capture a complete picture of the organizations sustainability impact. Private sector sustainability reporting is a more straightforward undertaking to understand. The content analysis revealed that most organizations publish a stand-alone sustainability report and reference the GRI. This is consistent with results from previous studies, for instance with the study conducted by Roca \& Searcy (2012), that also found that most Canadian companies included in the sample were using the GRI. 
While there is some degree of alignment between private and public sector sustainability goals and targets, it is clear that private and public organizations conceive of sustainability in different ways and focus on different priorities in their sustainability efforts. It was clear from the interviews that the term 'sustainability' had multiple meanings between, and even within, the public and private sectors. Most participants from the public sector tended to view sustainability involving a complex interplay of systems whereby a balance must be struck between environmental, social or cultural systems in order to meet the needs of future generations. Public sector organizations tended to view sustainability in terms of the different impacts directly associated with their business operations. The interviews also uncovered important differences regarding the motivators and drivers of sustainability reporting. For public sector organizations, sustainability reporting is posited distinctly as something beneficial to the community and its residents. Conversely, private sector organizations tended to see sustainability reporting as a key factor for their bottom line. Such disparities are a direct reflection of the different institutional environment and social license these organizations operate under.

\subsubsection{What are the potential benefits and risks of linking reporting between public and private sector sustainability reporting?}

The findings suggest that increased linkages between the public and private sectors in terms of sustainability reporting could bring about a range of benefits. A major benefit identified from the interviews was improved information sharing and shared conceptualizations related to sustainability. When governments and private sector organizations begin defining and approaching sustainability issues in the same ways, as well as start working toward similar goals and outcomes, greater progress can be made on key issues. Moreover, linkages could lead to better processes for monitoring the impacts of public and private sector organizations. The research also demonstrated that public-private partnerships are especially important for helping create such alignment both at 
the individual project level, as well as at the regional or national level. Fostering a stronger relationship between the two sectors was seen as a precursor to the development of more effective public policy and practice. Furthermore, one participant from the study indicated that establishing more linkages between government and company reporting could increase the credibility of private sector reports.

\subsubsection{What are barriers and challenges that may inhibit such alignment between private and public sector sustainability reporting from materializing?}

The process of linking sustainability reporting between the public and private sectors represents significant challenges. One of the key challenges in creating more congruity between public and private sector organizations vis-à-vis sustainability reporting relates to the need for organizations to identify those areas of shared goals and needs. Challenges related to linking include differing goals as well as differing ideas of what constitutes success. There is a specific need to first identify those mutual areas where efforts are already occurring. The findings from the content analysis show a number of such areas, including those related to water use, waste reduction, employee engagement, the reduction of greenhouse gas emissions, and more. In these and other areas, private and public organizations share important priorities and goals.

Another key challenge in achieving greater coordination and collaboration relates to the need for multiple perspectives to be included. If public sector organizations simply discount perspectives offered by private sector organizations, or vice versa, coordination will not be achieved. In this sense, an understanding of the need for equitable partnerships and collaboration is especially important. Organizations may be committed to the broader goals of sustainability; however, if goals are not established in ways which account for the unique considerations of organizations in both sectors, they will fail to generate the desired results. As such, it is especially important for coordination and collaboration efforts to determine the underlying reasons for 
different conceptualizations of specific issues. Because private and public sector organizations have unique needs and face unique constraints, coordination can only be achieved through an understanding of these issues.

\subsubsection{What are the trade-offs of linking reporting between public and private sector sustainability reporting?}

A final development from this study relates to the the trade-offs involved in linking reporting. Most participants interviewed for the study expressed concerns around the conception that linking reporting meant having to report sustainability information in the exact same ways. This meant that comparability was often seen as a competing objective with materiality. Therefore, an important distinction to make here is that linking reporting does not mean that reporting has to be done identically across the sectors. Both sectors need to be working towards the same broader sustainability goals, but the criteria and concepts to which they report on those goals may be justifiably different. In other words, common language and criteria should be enhanced where possible, but there may be some areas where certain criteria and concepts is relevant to only one sector. Therefore, reporting needs be done in a way that enables consistency and comparability, but at the same time accounts for the individual interests of the organization.

Another trade-off identified by participants involved the trade-off in resources. This was a significant concern expressed primarily among public sector organizations, who felt that linking reporting meant having to allocate additional resources to this process. Time spent reporting was seen as a trade-off with time spent actually carrying out their sustainability endeavors. This suggests that linking reporting may require additional funding from the Federal government to alleviate some of the resource constraints faced by the public sector. 


\subsubsection{Key Findings and Institutional Theory}

The findings from this research provide support for the institutional theory framework. As previously mentioned, institutional theory holds that organizations operating in similar environments are likely to adopt similar strategies in their efforts to conform to relevant goals, norms, and expectations (DiMaggio \& Powell, 1983). Public sector organizations including governments and others tend to view sustainability as involving a complex interplay of systems and thus requiring efforts to address the different problems. Conversely, private sector businesses tend to see sustainability as a key concern for their bottom line. This is a direct reflection of the environment these organizations operate in. While public sector organizations need to engage complex systems and processes, private sector organizations need to maintain profitability. Sustainability for both types of organizations is thus approached through an institutional lens.

The above findings indicate that public sector organizations primarily face the coercive and the mimetic mechanisms of isomorphism in their decision to report on their sustainability performance. This is evident in a number of cases. For instance, most of the sustainability reports produced by the public sector sample are based on the requirements set out by the government to obtain grants and funding. Moreover, during the interviews, public sector participants indicated they faced coercive pressure by government to report sustainability performance in order to comply with various regulations. Despite these reason, the study indicated that the primary motive for public sector reporting was to be viewed by the public as transparent and accountable. In this regard, public sector organizations are similar to the private sector in that sectors seek legitimacy and expect something to be gained from their appearing to be sustainable. For the public sector, it may be in the form of attracting residents or "green" businesses to their jurisdiction. Underscoring this point, the study found that like private sector reporting, more and more public sector 
organizations were offering their sustainability reports in a user-friendly web-based form. Offering online sustainability reports can be seen as an effort by the public sector to address the coercive pressure by the public for more up-to-date information. The study also found that public sector organizations were influenced by mimetic institutionalization. This is supported in the interview findings where respondents stated that they normally follow the reporting practices of other organizations of similar size and position in the midst of uncertainty.

Unsurprisingly, the results indicated that private sector organizations leveraged sustainability reporting as a public relations strategy. Indeed, the findings made it clear that sustainability reporting has become part of any business strategy to gain a competitive edge. This is acknowledged by most of the private sector respondents. Private sector organizations face coercive pressure primarily from the government, industry associations, and the public. For instance, participants in the mining sector indicated that they reported in order to adhere to various industry association obligations to which they are a part of. As such membership in such an association may influence sustainability reporting.

Furthermore, the high number of private sector reports using the GRI and other reporting standards, principles and guidelines, may be a result of the normative pressures exerted on the private sector to remain competitive in an increasingly professionalized environment. As public sector organizations operate in generally non-competitive environments, they are not subject to the same pressures. This again is line with the institutional theory proposition. Because these different types of organizations see sustainability in very different terms, alignment and coordination must come through efforts aimed at developing shared and mutual definitions and conceptualizations. This can promote alignment and greater progress on key issues. 


\section{Conclusion and Recommendations}

This study sought to investigate the sustainability reporting practices of public and private sector organizations with the goal of uncovering the similarities, differences, advantages, challenges, and other factors limiting coordination and similar approaches to reporting. A review of the findings suggests that the current relationship between the two sectors is weak and relatively independent from one another. As such, reporting is done diversely, with differences in report types, lengths, approach, content and scope. The differences in report content and scope is likely a result of the voluntary nature of sustainability reporting in Canada and the lack of a single, generally accepted standard. At the same time, participants from both sectors agreed that a more holistic approach to sustainability reporting, grounded in common language, and to the extent possible, shared criteria, is essential.

Public and private organizations face many challenges related to improved coordination and collaboration in their sustainability reporting, but these can potentially be addressed by developing shared ideas and conceptions wherever possible. Companies in the private sector may have an important role to play with regard to organizations in the public sector adopting new goals and sustainability targets. In this case, the research shows that private organizations in general do a better job establishing hard goals with clear metrics for evaluation. Private organizations could thus make important contributions regarding how public sector organizations can translate vague and non-specific goals related to sustainability to more concrete goals and actions aimed at achieving specific results. By leveraging insights from organizations in the private sector, local governments and other public sector organizations may be able to gain skills regarding framing goals in ways that allow for their improved evaluation and assessment. 
Linking reporting will also require efforts to uncover the reasons for different approaches and conceptions to different issues. For example, if public and private organizations conceive of land use in different ways, understanding the factors that go into these different conceptualizations is necessary for building shared approaches and understanding.

The findings suggest that the SDGs could serve as a potential platform to facilitate this. However, the research showed that there is an apparent lack of awareness on the SDGs from public sector representatives, particularly from the local level. This highlights the need for continued work on educating those in the public sector about the SDGs, as well as how they can specifically contribute to improved alignment in sustainability reporting.

Consultation and dialogue are particularly important if greater coordination and collaboration is to be achieved. The onus is on organizations in both sectors to share pertinent and sufficiently detailed information regarding the meanings they assign to different activities, as well as the reasons for their adopting particular perspectives in their sustainability work with key stakeholders. Only through an open and shared dialogue can stakeholders on both sides understand the reasons for differences in perspectives, and then work to bridge divides in ways that still allow organizations in both sectors to meet their most important goals and objective

To be sure, it is clear that with efforts aimed at mutual understanding, collaboration and cooperation can be achieved. Both private and public sector organizations recognize the importance of sustainability on an operational level. Overcoming the different ways they approach and prioritize issues can lead to more meaningful progress on key issues affecting local communities. At the same time, a lack of coordination in reporting and monitoring can lead to fragmented and piece-meal progress at best. In the coming years, both private and public sector institutions need to work together to identify those areas of common interest related to 
sustainability issues, as well as communicate their differences. This approach can lead to greater coordination, and with that, ultimately more progress in addressing key sustainability issues.

\subsection{Contribution of Study}

This research study is significant for a diverse array of stakeholders. Both private and public sector organizations have experienced a number of benefits related to their sustainability reporting practices, including increased transparency (White, 2009). Increasing transparency in operations can lead to various benefits, including those related to organizational reputation. By demonstrating the organization's commitment to sustainable practices, organizations can operate more transparently and signal their commitment to stakeholders affected by their operations, especially in relation to the content of disclosure related to goals and targets on sustainable development. Different goals and areas of focus arise from the unique and individualized conceptions of sustainability. An understanding of the current sustainability goals and targets that organizations are publicly choosing to commit themselves to allows organizations to reflect on their own reporting practices. Therefore, from a managerial perspective, it is anticipated that the results from this study will help both public and private sectors determine what goals and targets should be included in their reports and how they should be reporting on them. Furthermore, having an understanding of the disclosure practices of goals and targets can provide insight into how sustainability reporting guidelines can be improved.

An understanding of the areas of alignment between public and private sector reporting will help organizations identify potential opportunities as well as potential risks. Private sector organizations in particular will be better equipped to constructively engage in policy discussions and better understand their role in public policy. When public sector organizations are clearer about their goals and targets, it can improve decision making across different divisions and government 
levels. When both public and private sector organizations are reporting on clear goals and targets, it will improve accountability and external relationships with society overall.

From a research perspective, this study has provided a needed contribution to the literature in the field of sustainability reporting. While much of the existing literature on sustainability reporting has focused on the private sector or public sector independent of one another, very few studies have focused on the interception between the two. As such, this research study has addressed an area of knowledge that has not been rigorously mined. Furthermore, the research and understanding of public sector organizations is still poorly understood. Therefore, this research provides needed evidence on the sustainability reporting practices of public sector organizations in Canada. Given the potential impact that both these sectors can have on large populations, improvements in this area could yield substantial results. This could benefit these organizations, the public, and indeed, the global environment.

\subsection{Future Research}

During the course of this study, several opportunities for future research were identified. The study found that analyzing the commonalities with respect to the goals and targets covered by each sector is relatively straightforward, but more in-depth work is needed to test the practical application of linking reporting at the indicator level. Other research studies may include a comparison to the third-sector and include reports from crown corporations and/or nongovernmental organizations (NGOs). This research chose to exclude crown corporations and NGOs as they could not be neatly transposed as either a private or public sector. However, future research which seeks to compare the sustainability reporting of crown corporations may serve to be particularly fruitful. This is because crown corporations often follow a private-sector model while still maintaining public policy objectives. 
More research may be carried out on how the GRI, or other supporting guidelines, may be improved to enhance the relationship between public and private sector reporting. Future research can provide a comparison between reports drawn from the public and private sectors that have specifically utilized the GRI. In doing so, researchers can more easily identify similarities and points of alignment. Given the fairly recent introduction of the SDGs, more rigorous research on how it can be effectively utilized as a linking tool between public and private sector organizations is warranted. Since this study employed a case study method, future research may be done to determine whether or not the results from this study are similar to other parts of the world.

\subsection{Limitations of Study}

There are a number of limitations that could have impacted this research study. One of the largest issues concerns the sustainability reports. Although a wide range of sustainability reports are publicly available, they are not all written at the same time. The fact that they are written in different years means that some of the information in the reports can be dated. In addition, since the study focused solely on comprehensive public-sector sustainability reports, and excluded the evaluation of reporting done at the department or strategy-level, it is likely that some reporting was not included in the content analysis.

Another important limitation is the lack of standardization within sustainability reports themselves. Each sustainability report will use different terms or interpret the same terms in different ways. This makes it difficult to be sure that the reports mean the same thing even when they use the same terms. The fact that the study only involves companies and organizations in Canada means that the results don't necessarily apply to other countries. Other countries may have significantly different standards and approaches to sustainability reporting. As a result, further research will be required to see if this research is applicable in different countries. 
There are also a number of potential methodological issues that could limit this study. The fact that this study used semi-structured interviews without fieldwork means that there is no way to confirm the statements of leaders in organizations. This is important because there can be considerable differences between the policies and statements of managers and other leaders in an organization and what actually takes place in practice (Sergiovanni and Corbally, 1986). In a similar vein, the content analysis is limited solely to the information that the organizations have chosen to make publicly available. Therefore, the analysis may be limited, as organizations are more likely to disclose information that only reflects positive performance. Furthermore, content analysis is largely based on the interpretation of the researcher. This can result in biases that can distort the results of the analysis (Kirby, 2000, p. 146). 


\section{APPENDICES}




\section{Appendix A: List of 25 TSX Venture Exchange Organizations removed from original sample}

\section{TSXV Organization Description Sustainability Website Accessed}

Report/Website

\begin{tabular}{|c|c|c|c|}
\hline Altima Resources Ltd & Oil \& Gas & N/A & http://www.altimaresources.com \\
\hline Cadillac Ventures Inc. & Mining & $\mathrm{N} / \mathrm{A}$ & $\begin{array}{l}\text { http://www.cadillacventures.com/s/Ho } \\
\text { me.asp }\end{array}$ \\
\hline $\begin{array}{l}\text { Canoe Mining } \\
\text { Ventures Corp. }\end{array}$ & Mining & N/A & http://www.canoemining.com \\
\hline $\begin{array}{l}\text { Canadian Spirit } \\
\text { Resources }\end{array}$ & Oil \& Gas & $\mathrm{N} / \mathrm{A}$ & $\begin{array}{l}\text { http://www.csri.ca/investors/index.ph } \\
\mathrm{p}\end{array}$ \\
\hline SilverCrest Metals & Mining & $\mathrm{N} / \mathrm{A}$ & Website under construction \\
\hline HTC Purenergy Inc. & Energy & $\begin{array}{l}\text { Website has a } \\
\text { "corporate social } \\
\text { responsibility } \\
\text { section" with } \\
\text { goal/strategies, } \\
\text { environment and } \\
\text { health \& safety } \\
\text { headings }\end{array}$ & http://www.htcenergy.com/ \\
\hline CanaDream Corp & Rv Rentals & $\mathrm{N} / \mathrm{A}$ & http://www.canadream.com/ \\
\hline $\begin{array}{l}\text { StorageVault Canada } \\
\text { Inc. }\end{array}$ & $\begin{array}{l}\text { Self- } \\
\text { storage/Mo } \\
\text { ving }\end{array}$ & $\mathrm{N} / \mathrm{A}$ & $\begin{array}{l}\text { http://storagevaultcanada.com/invest } \\
\text { or-relations/financial-reports }\end{array}$ \\
\hline NWest Energy Corp & Oil \& Gas & N/A & http://www.nwestenergy.com \\
\hline Seair Inc & Cleantech & $\mathrm{N} / \mathrm{A}$ & http://www.seair.ca/investors/ \\
\hline Canada Coal & Mining & $\mathrm{N} / \mathrm{A}$ & http://www.canadacoal.com \\
\hline $\begin{array}{l}\text { Berkwood Resources } \\
\text { Ltd }\end{array}$ & Mining & N/A & $\begin{array}{l}\text { http://www.berkwoodresources.co } \\
\mathrm{m} /\end{array}$ \\
\hline Aphria Inc. & $\begin{array}{l}\text { Medical } \\
\text { Marijuana } \\
\text { Producer }\end{array}$ & N/A & https://aphria.com/ \\
\hline Tinka Resources Ltd & Mining & $\begin{array}{l}\text { Website has } \\
\text { section titled } \\
\text { "community/envir } \\
\text { onment" but } \\
\text { under } \\
\text { construction }\end{array}$ & $\begin{array}{l}\text { https://www.tinkaresources.com/c } \\
\text { ommunity }\end{array}$ \\
\hline $\begin{array}{l}\text { Shaw } \\
\text { Communications Inc. }\end{array}$ & $\begin{array}{l}\text { Communica } \\
\text { tions/Media }\end{array}$ & $\begin{array}{l}\text { Website has a } \\
\text { "community } \\
\text { involvement" } \\
\text { section which } \\
\text { outlines the } \\
\text { charities it } \\
\text { supports, as well }\end{array}$ & https://www.shaw.ca/store/ \\
\hline
\end{tabular}




\begin{tabular}{|c|c|c|c|}
\hline & & $\begin{array}{l}\text { as initiatives it } \\
\text { has started i.e. " } \\
\text { Shaw Rocket } \\
\text { Fund” }\end{array}$ & \\
\hline Cougar Minerals Corp & Mining & $\mathrm{N} / \mathrm{A}$ & $\begin{array}{l}\text { http://www.cougarminerals.com/i } \\
\text { nvestors/financial reports }\end{array}$ \\
\hline $\begin{array}{l}\text { Megastar } \\
\text { Development Corp }\end{array}$ & Mining & N/A & $\begin{array}{l}\text { http://www.megastardevelopment.co } \\
\mathrm{m}\end{array}$ \\
\hline GB Minerals & Mining & N/A & http://www.gbminerals.com \\
\hline Canlan Ice Sports & Retail & $\begin{array}{l}\text { Website has a } \\
\text { "Social } \\
\text { Responsibility" } \\
\text { section which } \\
\text { outlines the } \\
\text { charities that they } \\
\text { support }\end{array}$ & http://www.icesports.com/ \\
\hline $\begin{array}{l}\text { Tenth Avenue } \\
\text { Petroleum Corp }\end{array}$ & Oil \& Gas & $\mathrm{N} / \mathrm{A}$ & $\begin{array}{l}\text { http://tenthavenuepetroleum.com/env } \\
\text { ironment/ }\end{array}$ \\
\hline Uraven Minerals Inc. & Mining & N/A & $\begin{array}{l}\text { http://www.uravanminerals.com/corp } \\
\text { orate/about/ }\end{array}$ \\
\hline $\begin{array}{l}\text { Noble Minerals } \\
\text { Exploration }\end{array}$ & Mining & N/A & $\begin{array}{l}\text { http://www.noblemineralexploration.c } \\
\text { om/s/AnnualReports.asp }\end{array}$ \\
\hline Softrock Minerals & Mining & N/A & $\begin{array}{l}\text { http://www.softrockminerals.com/corp } \\
\text { orate.html }\end{array}$ \\
\hline Jet Metal Corp. & Mining & N/A & $\begin{array}{l}\text { http://www.jetmetalcorp.com/index.ph } \\
\text { p/corporate/annual-information-form }\end{array}$ \\
\hline Robex Resources Inc. & Mining & N/A & http://robexgold.com/en/about-us/ \\
\hline $\begin{array}{l}\text { Green Valley Mine } \\
\text { Inc. }\end{array}$ & Mining & N/A & http://www.greenvalleymine.com \\
\hline
\end{tabular}




\section{Appendix B: Content Analysis Worksheet (Private Sector)}

$\mathbf{Y}=\mathbf{Y e s}$

\begin{tabular}{|c|c|c|c|c|c|c|c|c|c|c|}
\hline Company & Report Title & $\begin{array}{l}\text { N. of } \\
\text { Pgs. }\end{array}$ & Year & $\underline{\Omega}$ & ڤุ & $\theta$ & 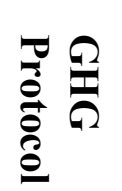 & 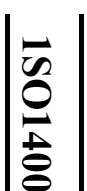 & 象 & 递 \\
\hline Algoma & Sustainability Report & 21 & 2015 & G4 & & & & & & \\
\hline $\begin{array}{l}\text { Arc } \\
\text { Resources }\end{array}$ & Sustainability report & 38 & 2014 & $\mathrm{Y}$ & & $\mathrm{Y}$ & & & & \\
\hline Artis REIT & Sustainability Report & 16 & 2015 & & & & & & & \\
\hline $\begin{array}{l}\text { Aura } \\
\text { Minerals }\end{array}$ & $\begin{array}{l}\text { Corporate } \\
\text { Responsibility Report }\end{array}$ & 56 & 2013 & G3.1 & & & $\mathrm{Y}$ & $\mathrm{Y}$ & & \\
\hline $\begin{array}{l}\text { Avalon } \\
\text { Minerals }\end{array}$ & Sustainability Report & 63 & 2015 & G4 & & & & & & \\
\hline BMO & $\begin{array}{l}\text { Environmental, Social } \\
\text { and Governance } \\
\text { Report and PAS }\end{array}$ & 70 & 2015 & G4 & $\mathrm{Y}$ & Y & $\mathrm{Y}$ & & & $\mathrm{Y}$ \\
\hline BMO & $\begin{array}{l}\text { Corporate } \\
\text { Responsibility Report }\end{array}$ & 42 & 2015 & G4 & $\mathrm{Y}$ & Y & Y & & & $\mathrm{Y}$ \\
\hline Barrick Gold & Responsibility report & 155 & 2015 & G3 & & $\mathrm{Y}$ & & $\mathrm{Y}$ & & $\mathrm{Y}$ \\
\hline Bell Canada & $\begin{array}{l}\text { Corporate Social } \\
\text { Responsbility Report }\end{array}$ & 75 & 2015 & G4 & $\mathrm{Y}$ & & & $\mathrm{Y}$ & & $\mathrm{Y}$ \\
\hline Blackberry & $\begin{array}{l}\text { Corporate } \\
\text { responsibility Report }\end{array}$ & 60 & 2014 & G3.1 & & $\mathrm{Y}$ & $\mathrm{Y}$ & $\mathrm{Y}$ & & $\mathrm{Y}$ \\
\hline Bombardier & Activity Report & 44 & 2015 & G4 & $\mathrm{Y}$ & & & $\mathrm{Y}$ & & $\mathrm{Y}$ \\
\hline CIBC & $\begin{array}{l}\text { Corporate } \\
\text { Responsibility Report } \\
\text { and (PAS) }\end{array}$ & 83 & 2015 & G4 & & $\mathrm{Y}$ & & $\mathrm{Y}$ & & \\
\hline $\begin{array}{l}\text { Canfor } \\
\text { Corporation }\end{array}$ & sustainability Report & 31 & 2014 & G4 & & & & & & \\
\hline $\begin{array}{l}\text { Capstone } \\
\text { Mining }\end{array}$ & Sustainability Report & 52 & 2014 & G4 & & & $\mathrm{Y}$ & & & \\
\hline $\begin{array}{l}\text { Catalyst } \\
\text { Paper }\end{array}$ & sustainability Report & 35 & 2015 & G4 & & $\mathrm{Y}$ & & $\mathrm{Y}$ & & \\
\hline Celestica & Sustainability Report & 88 & 2014 & G4 & & $\mathrm{Y}$ & Y & $\mathrm{Y}$ & & $\mathrm{Y}$ \\
\hline CGI Group & Environmental Report & 10 & 2014 & $\mathrm{~N}$ & & $\mathrm{Y}$ & $\mathrm{Y}$ & & & \\
\hline Cegeoco & $\begin{array}{l}\text { Corporate Social } \\
\text { Responsbility Report }\end{array}$ & 54 & 2015 & G4 & $\mathrm{Y}$ & & $\mathrm{Y}$ & & & \\
\hline Domtar Inc. & Sustainability Report & 35 & 2015 & G4 & & & & & & \\
\hline Encana & Sustainability Report & 34 & 2014 & G3.1 & & & & & & \\
\hline
\end{tabular}




\begin{tabular}{|c|c|c|c|c|c|c|c|c|c|c|}
\hline Company & Report Title & $\begin{array}{l}\text { N. of } \\
\text { Pgs. }\end{array}$ & Year & $\Omega$ & $\begin{array}{l}\mathcal{C} \\
2 \\
2\end{array}$ & $\underline{\sigma}$ & 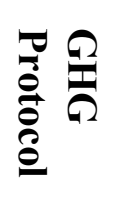 & $\frac{\tilde{\sigma}}{0}$ & $\mathscr{n}$ & 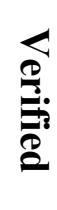 \\
\hline $\begin{array}{l}\text { First } \\
\text { Quantum } \\
\text { Minerals }\end{array}$ & Sustainability Report & 84 & 2014 & $\bar{Y}$ & & $\bar{Y}$ & $\bar{Y}$ & $\bar{Y}$ & & \\
\hline Genworth & $\begin{array}{l}\text { Public Accountability } \\
\text { Statement }\end{array}$ & 16 & 2014 & & & & & & & \\
\hline $\begin{array}{l}\text { Gold Corp } \\
\text { Inc }\end{array}$ & Sustainability Report & 176 & 2015 & G4 & $\mathrm{Y}$ & & $\mathrm{Y}$ & & $\mathrm{Y}$ & $\mathrm{Y}$ \\
\hline $\begin{array}{l}\text { Great West } \\
\text { Life }\end{array}$ & $\begin{array}{l}\text { Public Accountability } \\
\text { Statement }\end{array}$ & 60 & 2015 & G4 & & $\mathrm{Y}$ & & & & \\
\hline $\begin{array}{l}\text { Highliner } \\
\text { foods Canada }\end{array}$ & Sustainability Report & 9 & 2013 & & & & & & & \\
\hline Husky Energy & Community Report & 36 & 2014 & & & & & & & \\
\hline IAMGOLD & $\begin{array}{l}\text { Health, Safety and } \\
\text { Sustainability Report }\end{array}$ & $\begin{array}{l}\text { ONLI } \\
\text { NE }\end{array}$ & & G4 & Y & & & $\mathrm{Y}$ & & $\mathrm{Y}$ \\
\hline $\begin{array}{l}\text { Imperial Oil } \\
\text { Ltd. }\end{array}$ & $\begin{array}{l}\text { Corporate Citizenship } \\
\text { Report }\end{array}$ & 14 & 2015 & G3.1 & & Y & & $\mathrm{Y}$ & & $\mathrm{Y}$ \\
\hline $\begin{array}{l}\text { IGM } \\
\text { Financial Inc. }\end{array}$ & $\begin{array}{l}\text { Corporate } \\
\text { Responsibility Report }\end{array}$ & 47 & 2014 & G4 & & $\mathrm{Y}$ & $\mathrm{Y}$ & & & $\mathrm{Y}$ \\
\hline Innergex & $\begin{array}{l}\text { Sustainable } \\
\text { Development Report }\end{array}$ & 44 & 2014 & G4 & & & Y & & & \\
\hline Kinross Gold & $\begin{array}{l}\text { Corporate } \\
\text { Responsibility Report }\end{array}$ & 24 & 2014 & G3 & $\mathrm{Y}$ & Y & $\mathrm{Y}$ & & & $\mathrm{Y}$ \\
\hline KP Tissue & Sustainability report & 88 & 2015 & G4 & & & & & & \\
\hline Loblaws & $\begin{array}{l}\text { Corporate Social } \\
\text { Responsbility Report }\end{array}$ & 36 & 2015 & $\mathrm{Y}$ & & & & & & \\
\hline $\begin{array}{l}\text { Lundin } \\
\text { Mining } \\
\text { Corporation }\end{array}$ & Sustainability Report & 54 & 2015 & G4 & $\mathrm{Y}$ & $\mathrm{Y}$ & Y & $\mathrm{Y}$ & & $\mathrm{Y}$ \\
\hline $\begin{array}{l}\text { Maple leaf } \\
\text { foods }\end{array}$ & Sustainability Report & 24 & 2014 & G4 & & & & & & \\
\hline Metro & $\begin{array}{l}\text { Corporate } \\
\text { Sustainability Report }\end{array}$ & 31 & 2014 & & & $\mathrm{Y}$ & Y & & & \\
\hline Metro & CSR 2016-2020 Plan & 15 & 2015 & & & $\mathrm{Y}$ & $\mathrm{Y}$ & & & \\
\hline Morgaurd & Sustainability Report & 44 & 2015 & G3.1 & & & & & & \\
\hline $\begin{array}{l}\text { National } \\
\text { Bank of } \\
\text { Canada }\end{array}$ & $\begin{array}{l}\text { Social Responsibility } \\
\text { Report }\end{array}$ & 38 & 2015 & & & $\mathrm{Y}$ & & & & \\
\hline $\begin{array}{l}\text { Newalta } \\
\text { Corporation }\end{array}$ & Sustainability Report & 40 & 2014 & & & & & & & \\
\hline
\end{tabular}




\begin{tabular}{|c|c|c|c|c|c|c|c|c|c|c|}
\hline Company & Report Title & $\begin{array}{l}\text { N. of } \\
\text { Pgs. }\end{array}$ & Year & $\Omega$ & $\stackrel{9}{\Omega}$ & $\underline{\theta}$ & 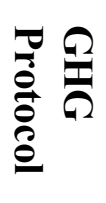 & $\frac{\tilde{\sigma}}{0}$ & $\mathscr{\Omega}$ & 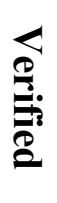 \\
\hline $\begin{array}{l}\text { Progressive } \\
\text { waste } \\
\text { solutions }\end{array}$ & Sustainability Report & 4 & 2014 & & & $\mathrm{Y}$ & & & & \\
\hline $\begin{array}{l}\text { Rogers } \\
\text { Communicati } \\
\text { ons }\end{array}$ & $\begin{array}{l}\text { Corporate Social } \\
\text { Responsbility Report }\end{array}$ & 75 & 2014 & G4 & & Y & Y & Y & & Y \\
\hline RONA Inc. & $\begin{array}{l}\text { Sustainable } \\
\text { Development Report }\end{array}$ & 13 & 2014 & & & $\mathrm{Y}$ & & & & \\
\hline SEMAFCO & $\begin{array}{l}\text { Sustainable } \\
\text { Development Report }\end{array}$ & 36 & 2014 & & Y & & & & & \\
\hline Sherritt Int & Sustainability Report & 75 & 2015 & G4 & & & & $\mathrm{Y}$ & & \\
\hline $\begin{array}{l}\text { Suncor } \\
\text { Energy }\end{array}$ & $\begin{array}{l}\text { Report on } \\
\text { Sustainability }\end{array}$ & 40 & 2015 & G3.1 & $\mathrm{Y}$ & $\mathrm{Y}$ & & Y & & Y \\
\hline $\begin{array}{l}\text { TD Financial } \\
\text { Group }\end{array}$ & $\begin{array}{l}\text { Corporate Social } \\
\text { Responsbility Report }\end{array}$ & 64 & 2015 & G4 & & $\mathrm{Y}$ & & & Y & Y \\
\hline $\begin{array}{l}\text { Teck } \\
\text { Resources }\end{array}$ & Sustainability Report & 134 & 2015 & G4 & $\mathrm{Y}$ & Y & $\mathrm{Y}$ & Y & $\mathrm{Y}$ & $\mathrm{Y}$ \\
\hline $\begin{array}{l}\text { Telus } \\
\text { Corporation }\end{array}$ & Sustainability Report & 169 & 2015 & G4 & Y & $\mathrm{Y}$ & Y & $\mathrm{Y}$ & Y & $\mathrm{Y}$ \\
\hline $\begin{array}{l}\text { TransAlta } \\
\text { Canada }\end{array}$ & Integrated Report & 202 & 2015 & & & $\mathrm{Y}$ & & & & Y \\
\hline Trans Canada & $\begin{array}{l}\text { Corporate Social } \\
\text { Responsbility Report }\end{array}$ & 96 & 2014 & & & $\mathrm{Y}$ & & $\mathrm{Y}$ & & \\
\hline West Fraser & Sustainability Report & 24 & 2015 & & & & & $\mathrm{Y}$ & & \\
\hline
\end{tabular}


Appendix C: Content Analysis Worksheet (Public Sector)

\begin{tabular}{|c|c|c|c|c|c|c|c|c|c|}
\hline Organization & Report Title & Year & $\begin{array}{l}\text { N. of } \\
\text { Pgs. }\end{array}$ & $\frac{\pi}{0}$ & $\begin{array}{l}\bar{\sigma} \\
\stackrel{8}{ \pm} \\
\stackrel{0}{0}\end{array}$ & 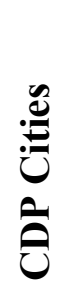 & $\underline{U}$ & $\underset{0}{0}$ & $\begin{array}{l}\bar{N} \\
\hat{0} \\
\mathscr{n}\end{array}$ \\
\hline Burlington & $\begin{array}{l}\text { State of } \\
\text { Environment } \\
\text { Report }\end{array}$ & 2015 & 148 & & & & & & \\
\hline Halifax & $\begin{array}{l}\text { Environmental } \\
\text { Strategy }\end{array}$ & 2013 & 97 & & $\mathrm{Y}$ & & & & \\
\hline Kingston & $\begin{array}{l}\text { Sustainable } \\
\text { Kingston Plan }\end{array}$ & 2010 & 68 & & & & & & \\
\hline Calgary & $\begin{array}{l}\text { Corporate } \\
\text { Environmental, } \\
\text { Health and } \\
\text { Safety Report }\end{array}$ & 2014 & 28 & & & & $\mathrm{Y}$ & & \\
\hline Calgary & $\begin{array}{l}\text { Annual } \\
\text { Progress on } \\
\text { Sustainable } \\
\text { Direction Plan }\end{array}$ & 2014 & 18 & & & & & & \\
\hline London & $\begin{array}{l}\text { Strategic Plan } \\
2015-2019\end{array}$ & $\begin{array}{l}2015- \\
2019\end{array}$ & 24 & & & & & & \\
\hline Oakville & $\begin{array}{l}\text { Lets go Green } \\
\text { Together: } \\
\text { Oakvilles } \\
\text { Environmental } \\
\text { Strategic } \\
\text { Progress Report }\end{array}$ & 2014 & 11 & & & & & & \\
\hline Oakville & $\begin{array}{l}\text { State of } \\
\text { Environment } \\
\text { Report (2014) }\end{array}$ & 2014 & 27 & & & & & & \\
\hline Waterloo & $\begin{array}{l}\text { Environmental } \\
\text { Strategy }\end{array}$ & 2015 & 45 & & $\mathrm{Y}$ & & $\mathrm{Y}$ & & \\
\hline Richmond Hill & $\begin{array}{l}\text { Greening the } \\
\text { Hill; } \\
\text { Environmental } \\
\text { Strategy }\end{array}$ & 2014 & 28 & & & & & & \\
\hline Regina & Strategic Plan & $\begin{array}{l}2014- \\
2018\end{array}$ & 14 & & $\mathrm{Y}$ & & & & \\
\hline Ottawa & $\begin{array}{l}\text { Environmental } \\
\text { Strategy }\end{array}$ & $\begin{array}{l}2003- \\
2020\end{array}$ & 87 & & & & & & \\
\hline Markham & $\begin{array}{l}\text { Markham } \\
\text { Community }\end{array}$ & $\begin{array}{l}2010- \\
2014\end{array}$ & 206 & $\mathrm{Y}$ & & & & & \\
\hline
\end{tabular}




\begin{tabular}{|c|c|c|c|c|c|c|c|c|c|}
\hline Organization & Report Title & Year & $\begin{array}{l}\text { N. of } \\
\text { Pgs. }\end{array}$ & 疍 & 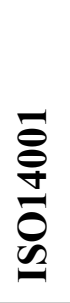 & 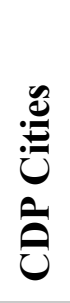 & ِّ & 总 & 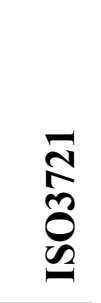 \\
\hline & $\begin{array}{l}\text { Sustainability } \\
\text { Plan }\end{array}$ & & & & & & & & \\
\hline Toronto & $\begin{array}{l}\text { Toronto } \\
\text { Environmental } \\
\text { Progress Report } \\
2015\end{array}$ & 2015 & 44 & & & Y & & & \\
\hline Guelph & $\begin{array}{l}\text { Corporate } \\
\text { Strategic Plan }\end{array}$ & $\begin{array}{l}2012- \\
2016\end{array}$ & 22 & & & & & & \\
\hline Cape Breton & $\begin{array}{l}\text { Integrated } \\
\text { Community } \\
\text { Sustainability } \\
\text { Plan }\end{array}$ & 2010 & 75 & & & & & & \\
\hline Edmonton & $\begin{array}{l}\text { Report on the } \\
\text { Environment }\end{array}$ & 2014 & 36 & & Y & Y & Y & & \\
\hline Vaughan & $\begin{array}{l}\text { Green direction } \\
\text { Plan }\end{array}$ & 2012 & 51 & & & & & & \\
\hline Greater Sudbury & $\begin{array}{l}\text { Greater } \\
\text { Sudbury Action } \\
\text { Plan } 2010\end{array}$ & 2010 & 65 & & & & Y & & \\
\hline Kelowna & $\begin{array}{l}\text { OCP } 2015 \\
\text { (Indicator } \\
\text { Report) }\end{array}$ & 2015 & 29 & & & & & & \\
\hline Brantford & $\begin{array}{l}\text { Strategic Plan } \\
\text { 2014-2018 }\end{array}$ & $\begin{array}{l}2014- \\
2018\end{array}$ & 18 & & & & & & \\
\hline Mississauga & $\begin{array}{l}\text { Living Green } \\
\text { Master Plan } \\
\text { Progress Report }\end{array}$ & 2012 & 22 & & & & & & \\
\hline Burnaby & $\begin{array}{l}\text { Environmental } \\
\text { Sustainability } \\
\text { Strategy Plan } \\
2015 \text { (Draft) }\end{array}$ & 2015 & 82 & & & & & & \\
\hline Oshawa & $\begin{array}{l}\text { Strategic Plan: } \\
\text { Creating our } \\
\text { Sustainable } \\
\text { Future }\end{array}$ & $\begin{array}{l}2015- \\
2018\end{array}$ & 20 & & & & & & \\
\hline Saanich & Strategic Plan & $\begin{array}{l}2015- \\
2018\end{array}$ & 36 & & & & Y & & \\
\hline Strathcona County & $\begin{array}{l}\text { Strategic Plan } \\
2013-2030\end{array}$ & $\begin{array}{l}2013- \\
2030\end{array}$ & 14 & & & & & & \\
\hline
\end{tabular}




\begin{tabular}{|c|c|c|c|c|c|c|c|c|c|}
\hline Organization & Report Title & Year & $\begin{array}{l}\text { N. of } \\
\text { Pgs. }\end{array}$ & $\frac{7}{0}$ & 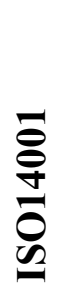 & 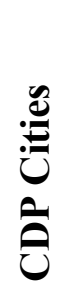 & $\tilde{U}$ & $\underset{0}{0}$ & 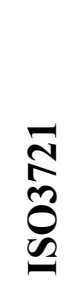 \\
\hline Winnipeg & $\begin{array}{l}\text { A sustainable } \\
\text { Winnipeg - } 25 \\
\text { year horizon }\end{array}$ & 2011 & 50 & & & & & & \\
\hline Saskatoon & $\begin{array}{l}\text { Environmental } \\
\text { Report to } \\
\text { Community }\end{array}$ & 2014 & 32 & & & & & & \\
\hline Barrie & $\begin{array}{l}\text { Community } \\
\text { report } 2014\end{array}$ & 2014 & 12 & & & & & & \\
\hline Ajax & $\begin{array}{l}\text { Integrated } \\
\text { Community } \\
\text { Sustainability } \\
\text { Plan } 2013\end{array}$ & 2013 & 128 & & & & $\mathrm{Y}$ & & \\
\hline Red Deer & $\begin{array}{l}\text { Environmental } \\
\text { Master Plan }\end{array}$ & 2011 & 182 & & & & $\mathrm{Y}$ & & \\
\hline Vancouver & $\begin{array}{l}\text { Greenest City } \\
\text { Progress Report }\end{array}$ & 2015 & 52 & & & $\mathrm{Y}$ & & & \\
\hline Kitchener & Strategic Plan & 2015 & 20 & & & & & & \\
\hline Abbotford & $\begin{array}{l}\text { Community } \\
\text { Sustainability } \\
\text { Strategy }\end{array}$ & 2013 & 20 & & & & & & \\
\hline Thunder Bay & $\begin{array}{l}\text { Sustainability } \\
\text { Plan 2014-2020 }\end{array}$ & $\begin{array}{l}2014- \\
2020\end{array}$ & 66 & & & & & & \\
\hline Pickering & $\begin{array}{l}\text { Measuring } \\
\text { Sustainability } \\
\text { Report } 2012\end{array}$ & 2012 & 100 & & & & & & \\
\hline Brampton & $\begin{array}{l}\text { Brampton's } \\
\text { Environmental } \\
\text { Master Plan } \\
2013\end{array}$ & 2013 & 65 & & & & & & \\
\hline Windsor & $\begin{array}{l}\text { State of } \\
\text { Environment } \\
\text { report }\end{array}$ & 2014 & 52 & & & & & & \\
\hline St. Catharines & $\begin{array}{l}\text { Sustainability } \\
\text { Strategy }\end{array}$ & 2011 & 56 & & & & & & \\
\hline St. Johns & $\begin{array}{l}\text { Integrated } \\
\text { Community } \\
\text { Sustainability } \\
\text { Plan }\end{array}$ & 2010 & 53 & & & & & & \\
\hline Kamloops & $\begin{array}{l}\text { Sustainable } \\
\text { Kamloops Plan }\end{array}$ & 2010 & 80 & & & & & & \\
\hline
\end{tabular}




\begin{tabular}{|c|c|c|c|c|c|c|c|c|c|}
\hline Organization & Report Title & Year & $\begin{array}{l}\text { N. of } \\
\text { Pgs. }\end{array}$ & $\frac{7}{0}$ & 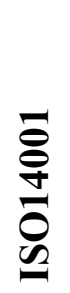 & 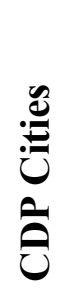 & $\tilde{U}$ & $\underset{0}{0}$ & 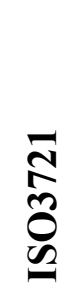 \\
\hline Hamilton & Strategic Plan & $\begin{array}{l}2016- \\
2025\end{array}$ & 12 & & $\mathrm{Y}$ & & & & \\
\hline Cambridge & $\begin{array}{l}\text { Corporate } \\
\text { Sustainability } \\
\text { Plan }\end{array}$ & 2011 & 90 & & & & & & \\
\hline Langley & $\begin{array}{l}\text { Sustainability } \\
\text { Framework }\end{array}$ & 2010 & 19 & & & & & & \\
\hline Clarington & Strategic Plan & $\begin{array}{l}2015- \\
2018\end{array}$ & 3 & & & & & & \\
\hline Surrey & $\begin{array}{l}\text { Sustainability } \\
\text { Charter }\end{array}$ & 2016 & 72 & & & $\mathrm{Y}$ & Y & $\mathrm{Y}$ & $\mathrm{Y}$ \\
\hline Richmond & $\begin{array}{l}\text { Sustainability } \\
\text { Progress Report } \\
2014\end{array}$ & 2014 & 48 & & & & & & \\
\hline Coquitlam & $\begin{array}{l}\text { Strategic Plan } \\
2016-2019\end{array}$ & $\begin{array}{l}2016- \\
2019\end{array}$ & 20 & & & & & & \\
\hline Chatham-Kent & $\begin{array}{l}\text { Community } \\
\text { Strategic } \\
\text { Planning } \\
\text { Annual report }\end{array}$ & Annual & 13 & & & & & & \\
\hline North Vancouver & $\begin{array}{l}\text { Living City } \\
\text { Report }\end{array}$ & 2013 & 8 & & & & Y & & \\
\hline Whitby & $\begin{array}{l}\text { Official Plan } \\
\text { (Website) }\end{array}$ & Online & 202 & & & & & & \\
\hline Delta & $\begin{array}{l}\text { Official } \\
\text { Community } \\
\text { Plan }\end{array}$ & 2015 & 128 & & & & Y & & \\
\hline Alberta & $\begin{array}{l}\text { State of } \\
\text { Environment } \\
\text { Report }\end{array}$ & 2015 & $\mathrm{n} / \mathrm{a}$ & & & & & & \\
\hline British Columbia & $\begin{array}{l}\text { Environmental } \\
\text { Report }\end{array}$ & 2015 & $\mathrm{n} / \mathrm{a}$ & & & & & & \\
\hline $\begin{array}{l}\text { Northwest } \\
\text { Territories }\end{array}$ & $\begin{array}{l}\text { State of the } \\
\text { Environment } \\
\text { Report }\end{array}$ & 2015 & 20 & & & & & & \\
\hline Nova Scotia & $\begin{array}{l}\text { Environmental } \\
\text { Goals and } \\
\text { Sustainability } \\
\text { Prosperity } \\
\text { Report }\end{array}$ & 2015 & 60 & & & & & & \\
\hline
\end{tabular}




\begin{tabular}{|c|c|c|c|c|c|c|c|c|c|}
\hline Organization & Report Title & Year & $\begin{array}{l}\text { N. of } \\
\text { Pgs. }\end{array}$ & $\frac{7}{0}$ & 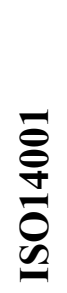 & 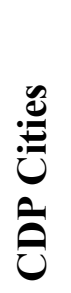 & $\underline{U}$ & 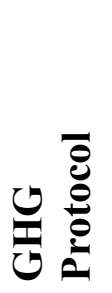 & 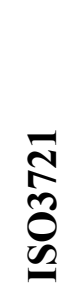 \\
\hline $\begin{array}{l}\text { Prince Edward } \\
\text { Island }\end{array}$ & $\begin{array}{l}\text { State of } \\
\text { Environment } \\
\text { Report }\end{array}$ & 2010 & 66 & & & & & & \\
\hline Quebec & $\begin{array}{l}\text { Sustainable } \\
\text { Development } \\
\text { Strategy Report }\end{array}$ & 2015 & 4 & & & & & & \\
\hline Saskatchewan & $\begin{array}{l}\text { State of } \\
\text { Environment } \\
\text { Report }\end{array}$ & 2015 & 92 & & & & & & \\
\hline Yukon & $\begin{array}{l}\text { State of } \\
\text { Environment } \\
\text { Report }\end{array}$ & 2015 & 44 & & & & & & \\
\hline Canada & $\begin{array}{l}\text { Federal } \\
\text { Sustainable } \\
\text { Development } \\
\text { Strategy } \\
\text { Progress Report }\end{array}$ & 2015 & 145 & & & & & & \\
\hline
\end{tabular}




\section{Appendix D: Copy of Consent Form sent to interview participants}

RYERSON

UNIVERSITY

\section{Ryerson University \\ Consent Agreement}

You are being invited to participate in a research study. Please read this consent form so that you understand what your participation will involve. Before you consent to participate, please ask any questions to be sure you understand what your participation will involve.

\section{LINKING PUBLIC AND PRIVATE SECTOR SUSTAINABILITY REPORTING}

\section{INVESTIGATORS:}

This research study is being conducted by Sharmilla Raj and Dr. Cory Searcy, from the Environmental Applied Science and Management Program at Ryerson University

\section{PURPOSE OF THE STUDY:}

The purpose of the study is to determine the linkages between public and private sector sustainability reporting. The study will be recruiting a maximum of 100 participants. The results of this research study will contribute to a graduate masters thesis.

\section{WHAT PARTICIPATION MEANS:}

If you volunteer to participate in this study, you will be asked to do the following things:

- Participants will be asked to partake in a 20-30-minute interview

- Interviews will be conducted over the phone or via Skype

- Participants names will be kept confidential

- The participants will be speaking on their own behalf and not on behalf of the organization to which they are employed

- Participants may decline to answer any of the interview questions and also stop participating at any time

- Sample questions may include:

1. How would you define sustainability?

2. Should sustainability reporting between the public and private sector be more aligned?

- Interviews will be recorded, transcribed and sent to the participant for verification

- The results from the study will be made available to participants - copies of the completed thesis will be sent to participants via email, or a hard-copy may be mailed to them upon request 


\section{POTENTIAL BENEFITS:}

This study will provide no direct benefit to the participant. However, I hope that the results of my study will be of benefit to organizations engaging in sustainability reporting by providing insight on how to improve and guide their sustainability reporting practices.

Furthermore, I hope that this study will benefit the broader research community. While much of the existing literature on sustainability reporting has focused on the private sector or public sector independent of one another, very few studies have focused on the interception between the two. As such, this research study will address an area of knowledge that has yet to be fully mined.

\section{WHAT ARE THE POTENTIAL RISKS TO YOU AS A PARTICIPANT:}

The potential risks for participation in this study are very low. Risks may involve personal identity being identified directly (name of participant) or inadvertently (through occupation title or organization/professional affiliation).

Any information provided by an individual participant as a result of their participation in the study will be considered confidential and will not be released unless the participant gives consent. To ensure confidentiality, names associated with raw data will be replaced immediately by an alphanumerical coding system with no identifying information, which could directly or inadvertently breach confidentiality. Furthermore, to help protect participant confidentiality, the final paper will not refer to a participant's organization and will only refer to whether they are from the private or public sector, and the specific industry they belongs to (i.e. mining, oil \& gas, etc.). When consent is obtained, the consent form will be stored separate from participants' contact information and other information collected from them during the study.

With your permission, the interview will be audio recorded to facilitate collection of information, and later transcribed for analysis. Shortly after the interview has been completed, I will send you a copy of the transcript to give you an opportunity to confirm the accuracy of our conversation and to add or clarify any points that you wish. All information you provide is considered completely confidential. Your name will not appear in any thesis or report resulting from this study, however, with your permission, direct quotations may be used. Data collected during this study will be retained for 5 years in a locked office. This is standard for studies such as this. Only my research supervisor and myself will have access. Once no longer required, all raw data will be erased, computer files will be deleted and audio-recorded tapes will be destroyed.

Participants will not be paid for their participation in this study.

\section{VOLUNTARY PARTICIPATION AND WITHDRAWAL:}

Participation in this study is completely voluntary. You may decline to answer any of the interview questions if you so wish. You may also stop participating at any time. If you choose to withdraw your consent, your data will also be withdrawn and destroyed. Your choice of whether 
or not to participate will not influence your future relations with Ryerson University or the investigators involved in the research.

\section{QUESTIONS ABOUT THE STUDY:}

If you have any questions regarding this study, or would like additional information to assist you in reaching a decision about participation, please contact me at by email at srraj@ryerson.ca. You can also contact my supervisor, Professor Dr. Cory Searcy at 416- 979-5000 x. 2095 or email cory.searcy@,ryerson.ca.

This study has been reviewed by the Ryerson Research Ethics Board. However, the final decision about participation is yours. If you have any comments or concerns resulting from your participation in this study, please contact:

Ryerson Research Ethics Board

c/o Office of the Vice President, Research and Innovation

Ryerson University

350 Victoria Street

Toronto, ON M5B 2K3

416-979-5042

rebchair@,ryerson.ca

\section{LINKING PUBLIC AND PRIVATE SECTOR SUSTAINABILITY REPORTING}

\section{CONFIRMATION OF AGREEMENT:}

Your signature below indicates that you have read the information in this agreement and have had a chance to ask any questions you have about the study. Your signature also indicates that you agree to participate in the study and have been told that you can change your mind and withdraw your consent to participate at any time. You have been given a copy of this agreement. You have been told that by signing this consent agreement you are not giving up any of your legal rights.

\section{Name of Participant (please print)}

Signature of Participant

Date

I agree to be audio- recorded for the purposes of this study. I understand how these recordings will be stored and destroyed. 
I agree to allow unattributed quotations from the interviews to be used for the purposes of this study. 


\section{Appendix E: Sample Interview Email Invitation}

Dear (insert name),

My name is Sharmilla Raj and I am a Master's student working under the supervision of Dr. Cory Searcy in the Environmental Applied Science and Management program at Ryerson University. I am contacting you because we are conducting a study that compares sustainability reporting in the public and private sector. The purpose of the study is to learn how stronger alignment between the two sectors can be fostered with respect to how they are reporting on sustainability issues. The title of the thesis is "Linking Public and Private Sector Sustainability Reporting".

We are currently seeking experts in the field of sustainability to participate voluntarily in a short 20-30 minute phone interview. Should you choose to participate, you will be speaking on your own behalf and not on behalf of the organization to which you are employed. Participants will be asked general questions regarding sustainability reporting. Sample questions may include "How would you define sustainability?" and "What do you feel are the similarities and difference between public and private sector sustainability reporting"? To ensure confidentiality, participant names will be replaced immediately by an alphanumerical coding system with no identifying information, which could directly or inadvertently breach confidentiality. Furthermore, the final paper will not refer to a participant's organization and will only refer to whether they are from the private or public sector. Given your role as the (insert position title) at (insert organization), I feel that you would provide great insight for this study.

This study has been reviewed by the Ryerson Research Ethics Board. If you have any questions or concerns about your rights as a participant or about the way the study is being conducted, please feel free to contact Toni Fletcher, the Research Ethics Coordinator, at 416-979-5000, Ext. 7112 or by email toni.fletcher@,ryerson.ca

Please find attached a document entitled "Ryerson University Research Consent Form". It provides further detail on the study and what participation entails. Once you have agreed to participate, it must be signed and returned back to me.

If you have any questions regarding this study or would like additional information to assist you in reaching a decision about participation, please contact me by email, srraj@,ryerson.ca or at 647282-7117. You may also contact my supervisor, Dr. Cory Searcy, at $\overline{416-979-5000, \text { Ext. } 2095 \text { or }}$ by email cory.searcy@,ryerson.ca.

We would like to thank you in advance for your time and consideration. I will be following up with you in a few days to see if you are interested in being interviewed. Your participation would be greatly appreciated.

Kind regards,

Sharmilla Raj

Masters Candidate, Environmental Applied Science and Management

Ryerson University 


\section{Appendix F: Copy of Interview Questionnaire Guide \\ Interview Questionnaire Guide}

Date/Time:

Participant Code Number: Industry/Sector:

Occupation/Job title:

Question 1: How would you define the term Sustainability?

Question 2: What do you think are the most prominent motivators/drivers of sustainability reporting in the (insert sector)?

Question 3: Do you feel as though the (insert sector) is doing a good job on sustainability reporting, why or why? If not, how do you think that they can improve?

Question 4: Do you think it is important for organizations to report on clear goals and targets with respect to sustainability?

Question 5: Do you feel that a standardized approach to sustainability reporting is effective? Why or why not?

Question 6: What do you feel are the key similarities \& differences between public and private sector organizations with respect to sustainability reporting?

Question 7: Do you think organizations in the (insert sector) are influenced by the (insert sector) when deciding what to report on/include in their sustainability reports?

If yes, how do you think they are influenced?

Question 8: What do you think the advantages are of closer alignment of sustainability reporting between public and private sector sustainability reporting?

Question 10: What do you think are the challenges, barriers and risks involved in linking sustainability reporting between the public and private sector sustainability reporting, and how do you think that they can be mitigated/overcome?

Question 11: How can sustainability reporting between the public and private sectors be more closely aligned/linked?

Question 12: Are you aware of the UN SDGs? If so, do you think the they can be used as a potential reporting framework or tool for linking sustainability reporting between the public and private sector? 


\section{$\underline{\text { References }}$}

Adams, C. (2002). International organizational factors influencing social and ethical reporting: Beyond current theorizing. Accounting, Auditing and Accountability, 15 (2), 223-250

Adams, C.A., Muir, S., \& Hoque, Z. (2014). Measurement of sustainability performance in the public sector. Sustainability Accounting, Management and Policy Journal, 5(1), 46-67

Alcaraz-Quiles, F. J., Navarro-Galera, A., \& Ortiz-Rodríguez, D. (2013). A comparative analysis of transparency in sustainability reporting by local and regional governments. Lex Localis, 55-78.

Amran, A.B., \& Devi, S.S. (2007). Corporate social reporting in Malaysia: An institutional perspective. World Review of Entrepreneurship, Management and Sustainable Development, 3(1).

Antoni, M., \& Hurt, Q. (2006). Applying the Global Reporting Initiative (GRI) for public bodies in the South African context: the eThekwini experience. Development Southern Africa, 23(2), 251-263.

Barley, S. R., \& Tolbert, P. S. (1997). Institutionalization and structuration: Studying the links between action and institution. Organization Studies, 18: 93-117.

Ball, A. \& Bebbington, J. (2008), Editorial: Accounting and reporting for sustainable development in public service organizations. Public Money \& Management, 323-326.

Ball, A. \& Grubnic, S. (2007), Sustainability accounting and accountability in the public sector. Sustainability Accounting and Accountability Routledge, UK, 243 - 265.

Barkemeyer, R., Preuss, L., \& Lee, L. (2014). On the effectiveness of private transnational governance regimes - Evaluating corporate sustainability reporting according to the Global Reporting Initiative. Journal of World Business, 50, (2), 312-325

Baron R. (2014). The evolution of corporate reporting for integrated performance. Background paper for the 30th Round Table on Sustainable Development. OECD, Paris.

Beare, D., Buslovich, R., \& Searcy, C. (2014). Linkages between corporate sustainability reporting and public policy. Corporate Social Responsibility and Environmental Management, 21(6), 336-350.

Bellringer, A., Ball, A., \& Craig, R. (2011) Reasons for sustainability reporting by New Zealand local governments, Sustainability Accounting, Management and Policy Journal, 2(1), pp. 126-138. 
Behnam, M., \& MacLean, T. L. (2011). Where is the accountability in international accountability standards?: A decoupling perspective. Business Ethics Quarterly, 21(1), $45-72$.

Blanco E., Rey Maquiera, J., \& Lozano, J. (2009). The economic impacts of voluntary environmental performance of firms: a critical review. Journal of Economic Surveys, 23 (3), 462-502

Blumenthal, D. S., \& DiClemente, R. J. (2004) Community-Based Health Research: Issues and Methods, New York, NY, Springer.

Boston College Center for Corporate Citizenship \& Ernest \& Young LLP (2013). Value of Sustainability Reporting.

Brown, S.H., De Jong, M., \& Lessidrenska, T. (2009). The rise of the Global Reporting Initiative: a case of institutioal entrepreneurship. Journal of Environmental Politics. 18 (2), 182200

Brown, S. H., De Jong, M., Levy, D.L. (2009b). Building institutions based on information disclosure: lessons from the GRI's sustainability reporting. Journal of Cleaner Production. 17(6): 571-580

Cargan, L. (2007). Doing Social Research. Lanham, MD: Rowman \& Littlefield.

Carroll, A.B. (1979). A three-dimensional conceptual model of corporate social performance. Academy of Management Review, (4) 4, 497-505.

CGA-Canada. (2005). Measuring Up: A study on sorproate sustainability reporting In Canada. Retrieved November 2016 from: http://www.cgacanada.org/enca/ResearchReports/ca rep 2005-06 sustainability.pdf

Chesterman, S., Johnstone, I., \& Malone, M. (2016) Law and Practice of the United Nations. New York: Oxford University Press, Google Books .Web. Nov. 2016. http://books.google.com

Clapp, J. (2005). Global environmental governance for corporate responsibility and accountability. Global Environmental Politics, 5(3), 23-34.

Committee for Economic Development (CED). (1971). Social responsibilities of business corporations. New York.

Cooper, S. M., \& Owen, D. L. (2007). Corporate social reporting and stakeholder accountability: The missing link. Accounting, Organizations and Society, 32(7-8), 649-667.

Conroy, M. M., \& Iqbal, A. (2009). Adoption of sustainability initiatives in Indiana, Kentucky, and Ohio. Local Environment, 14 (2), 109-125. 
Corina, J., Pilcher, R., \& Taplin, R. (2014). Malaysian local government internet sustainability reporting. Pacific Accounting Review, 26 (1/2), 75-93

Cowan, D.M., Dopart, P., Ferracini, T., Sahmel, J., Merryman, K., Gaffney, S. \& et al. (2010). A cross-sectional analysis of reported corporate environmental sustainability practices. Regulatory Toxicology and Pharmacology, 58, 524-538.

Crespy, C. T., \& Miller, V. V. (2011). Sustainability reporting: A comparative study of NGOs and MNCs. Corporate Social Responsibility and Environmental Management, 18(5), 275284.

CFERF. (2009). Corporate sustainability reporting in Canada. Retrieved September 2016 from Canadian Financial Executives Research Foundation: https://www.feicanada.org/

Daub, C. (2007). Assessing the quality of sustainability reporting: An alternative methodological approach. Journal of Cleaner Production, 15(1), 75-85.

Davis, G., \& Searcy, C. (2010). A review of Canadian corporate sustainable development reports. Journal of Global Responsibility. 1(2), 316-329

Deopoers, F., Jeanjean, T., \& Jerome, T.J. (2016). Voluntary disclosure of greenhouse gas emissions: Contrasting the carbon disclosure project and corporate reports. Journal of Business Ethics, 134 (3), 445-461

DiMaggio, P.J., Powell, W.W. (1983). The iron cage revisited: institutional isomorphism and collective rationality in organizational fields. American Sociological Review, 48, 147160.

Drori, G. S., Meyer, J. W., \& Hwang, H. (2006). Globalization and organization: World society and organizational change. Oxford: Oxford University Press.

Dumay, J., Guthrie, J., \& Farneti, F. (2010). GRI sustainability reporting guidelines for public and third sector organizations: a critical review. Public Management Review, 12(4), 531-548.

Ebner, D., \& Baumgartner, RJ. (2006). The relationship between sustainable development and corporate social responsibility. Paper presented at the Corporate Responsibility Research Conference 2006. Dublin, Ireland. Retrived from www.crrconference.org

Elkington, J. (1998). Cannibals with forks. The triple bottom line of $21^{\text {st }}$ century business. Stony Creek, CT: New Society Publishers.

Ely, M., Anzul, M., Friedman, T., Garner, D., \& Steinmetz, A. M. (1991). Doing qualitative research: Circles within circles. London: The Falmer Press.

Ehrenfeld, J.R. (2005). The roots of sustainability. MIT Sloan Management Review. 46 (2), 22-25 
Farneti, F., \& Guthrie, J. (2009). Sustainability reporting by Australian public sector organisations: Why they report. Accounting Forum, 33(2), 89-98.

Frias-Aceituno, J.-V., Rodriguez-Ariza, L., \& Gonzalez-Bravo, M.-I. (2009). The effect of societal values on local government transparency: Applying Hofstede's cultural dimmensions. Lex Localis, 11(4), 829-850.

Freeman, R. E. (1984). Strategic management: A stakeholder approach. Pitman Publishing Inc., Marshfield, Boston.

Federal Sustainable Development Act, S.C. 2008, c. 33. Retrieved November $28^{\text {th }} 2016$ from: lois.justice.gc.ca/eng/acts/F-8.6/page-1.html

Gaither, T. K. (2007). Building a Nation's Image on the World Wide Web. Youngstown: Cambria Press.

Green Growth Knowledge Platform (GGKP). (2013). Moving towards a common approach on green growth indicators. A Green Growth Knowledge Platform Scoping Paper, Seoul, Paris, Nairobi and Washington DC: Global Green Growth Institute, Organization for Economic Co-operation and Development, United Nations Environment Programme and World Bank.

Given, L. M. (Ed.). (2008). The SAGE Encyclopedia of Qualitative Research Methods. Thousand Oaks: Sage Publications.

Goswami, K \& Lodhia, S. (2012). Influences on sustainability reporting practices in selected South Australian local councils: An explanatory case study. University of South Australia, Adelaide, Australia.

Government of Ontario (2016). Energy Conservation and Demand Management. Retrieved November 24, 2016 from: https://www.ontario.ca/laws/regulation/110397

Gray, R., Kouchy, R., and Lavers, S. (1995). Corporate social and environmental reporting: A review of the literature and longitudinal study of UK disclosures. Accounting, Auditing and Accountability Journal, 8 (2),47-77.

Gray, R.H (2006) Social, environmental and sustainability reporting and organizationa value creation? Whose value? Whose creation? Accounting, Auditing \& Accountability Journal, $19(6), 793-819$

Gray, R. H \& Milne, M. (2004). Towards reporting on the triple bottom line: mirages, methods and myths. J. (Eds). Earthscan, London, 70-80

Global Reporting Initiative (2005), Sector Supplements for Public Agencies. 
GRI (2012). Mapping global reporting initiative against public sector reporting requirements in Australia. Retrieved from: https:/www.globalreporting.org/resourcelibrary/Publicsector-sustainability-reporting-remove-the-clutter\%20reduce-the-burden.pdf

GRI (2013). Sustainable Reporting Guidelines Version 4.0 (G4). Retrieved from: https://www.globalreporting.org/resourcelibrary/GRIG4-Part1-Reporting-Principlesand-Standard-Disclosures.pdf

GRI, UNGC and WBCSD (2015). SDG Compass: The guide for business action on the SDGs, Global Reporting Initiative, UN Global Compact and World Business Council for Sustainable Development, http://sdgcompass.org/wpcontent/uploads/2015/12/019104_SDG_Compass_Guide_2015.pdf.

Guthrie, J., \& Farneti, F. (2008). GRI Sustainability Reporting by Australian public sector organizations. Public Money \& Management, 28(6), 361-366.

Gwet, L. Kilem. (2008). Intrarater reliability. Wiley Encyclopedia of Clinical Trials. Retrieved from: http://www.agreestat.com/research papers/wiley encyclopedia2008 eoct631.pdf

Haffar, M. and Searcy, C. (2015). Classification of trade-offs encountered in the practice of corporate sustainability. Journal of Business Ethics, 1-28.

Hahn, R., \& Kuhnen, M. (2013). Determinants of sustainability reporting: A review of results, trends, theory, and opportunities in an expanding field of research. Journal of Cleaner Production, 59, 5-21.

Halme, M. \& Laurila, J. (2008). Philanthropy, integration or innovation? Exploring the financial and societal outcomes of different types of corporate responsibility. Journal of Business Ethics, 84 (3), 325-339

Hanks, J., Baxter, D. (2014). Evaluating the G4 guidelines. Accountancy SA. 34, 34-36

Hargroves, K. J., \& Smith, M. H. (2005). The Natural Advantage of Nations: Business opportunities, innovations and governance in the 21st Century. London: Earthscan.

Haveman, H. (1993). Follow the leader: Mimetic isomorphism and entry into new markets. Administrative Science Quarterly. 38 (4), 593-627.

Higgins, C., Milne, M.J., \& van Gramberg, B.J. (2015). The uptake of sustainability reporting in Australia. Journal of Business Ethics, 129 (2), 445-468

Hodge, T. S., Holtz, C. Smith \& K. H. Baxter (eds.). (1995). Pathways to sustainability: Assessing our progress. National round table on the environment and the economy, Ottawa, Ontario, 229 
Hoekstra R, Smits J, Boone K, Van Everdingen W, Mawire F, Buck B, Beutling A \& Kriege K. (2014). Measurement of sustainable development at the national, company and product level: The potential for alignment in a post-2015 world. Statistics Netherlands, The Sustainability Consortium, and Global Reporting Initiative.

Hopkins, M. (2003). The planetary bargain: corporate social responsibility matters. Earthscan Publications Ltd, London.

The Institute of Internal Auditors (IIA). (2011). Supplemental Guidance: Public sector definition. Retrieved September 2016 from: www. Globilia.org

Infrastructure Canada. (2016). The Federal Gas Tax Fund: Permanent and predictable funding. Retrieved November 24, 2016 from: http://www.infrastructure.gc.ca/plan/gtf-fteeng.html

The International Organization of Supreme Audit Institutions (INTOSAI). (2013). Sustainability reporting: concepts, frameworks and the role of the supreme audit institutions.

Retrieved from:

http://www.environmentalauditing.org/LinkClick.aspx?fileticket=vM4hrHlBd0s\%3D\&t $\underline{\text { abid }=128 \& \operatorname{mid}=568}$

Ioannou, I., and G. Serafeim. 2011. The consequences of mandatory corporate sustainability reporting. Working paper, London Business School

International Institute for Sustainable Development (IISD). (2010). Sustainable development: from Brundtalnd to Rio 2012. New York: United Nations. Retrieved from: http://www.surdurulebilirkalkinma.gov.tr/wpcontent/uploads/2016/06/Background_on_Sustainable_Development.pdf

International Institute for Sustainable Development (IISD). (1992). Business Strategies for Sustainable Development. Winnipeg, Canada.

Isenmann, R, Bey, C, \& Welter, M. (2007). Online reporting for sustainability issues. Business Strategy and the Environment, 16, 487-501.

Jepson, E., (2001) Sustainability and planning: Diverse concepts and close associations. Journal of Planning Literature, 15 (4), 503

Johnston, P., Everard, M., Santillo, D., \& Robert, K-H. (2007). Reclaiming the definition of sustainability. Journal of Environmental Science Pollution Research. 14 (1), 60-66.

Keating, Michael. (1993). The Earth Summit's Agenda for Change: A Plain language version of Agenda 21 and the other Rio Agreements. Geneva: Centre for Our Common Future

Kirby, M. (2000). Sociology in Perspective, AQA Edition, Oxford, UK., Hiennemann Educational Publishing. 
Kolk, A., Levy, D., \& Pinkse, J. (2008). Corporate responses in an emerging climate regime: The institutionalization and commensuration of carbon disclosure. European Accounting Review, 17(4), 719-45.

KPMG (2013). The KPMG Survey of Corporate Responsibility Reporting 2013. Retrieved from https://www.kpmg.com/Global/en/IssuesAndInsights/ArticlesPublications/corporateresponsibility/Documents/kpmg-survey-of-corporate-responsibility-reporting-2013.pdf

KPMG (2014). Canada country mining guide. Retrieved from:

https://www.kpmg.com/Ca/en/industry/Mining/Documents/KPMGMining-countryguide-Canada.pdf

Krippendorf, K. (1980). Content analysis: An introduction to its methodology. Sage, Newbury Park, CA.

Landis, J. R., \& Koch, G. G. (1977). The measurement of observer agreement for categorical data. Biometrics, 33, 159-174.

Lewis, T. (2008). Debate: Public sector sustainability reporting - Implications for accountants. Public Money \& Management, 28(6), 329-331.

Light, R. J., Singer, J. D., \& Willett, J. B. (1990). By Design: Planning Research on Higher Education. Harvard University Press.

Lodhia, S., Jacobs, K. \& Park, Y.J. (2012), Driving Public Sector Environmental Reporting: The disclosure practices of Australian commonwealth departments, Public Management Review, 14(5), 631-647.

Lombardi R, Rossi N, \& Russo, G. (2012). Innovative forms of accountability in the public administration: sustainability reports. Journal of US-Chine Public Administration. 9 (10), 1107-1121.

London, L. (2012). Sustainability in the private and public sectors: A comparison of motivators, actions, barriers and reporting of results. Diss. The University of Texas at Arlington. Web.

MacLean, R., \& Rebernak, K. (2007). Closing the credibility gap: The challenges of corporate responsibility reporting. Environmental Quality Management, 16(4), 1-6.

Measure What Matters, 2014. Discussion Paper Water: Accounting for shared priorities.

Mathews, M. R. (1997). Towards a mega-theory of accounting. Asia-Pacific Journal of Accounting, 4(2), 273-289 
Matisoff, D., Noonan, D., \& O'Brien, J. (2012). Convergence in environmental reporting: assessing the carbon disclosure project. Business Strategy and the Environment, 22(5), 285-305

McCracken, G. (1988). The long interview: Qualitative research methods. Newbury Park, CA: SAGE Publications.

McKinsey \& Company. (2011). The Business of Sustainability: McKinsey global survey results. McKinsey Quarterly. Retrieved November, 2016 from: http:/www.mckinsey.com/business-functions/sustainability-and-resourceproductivity/our-insights/the-business-of-sustainability-mckinsey-global-survey-results

Meyer, J.W \& Rowan, B. (1977). Institutionalized organizations: Formal structure as myth and ceremony. American Journal of Sociology, 83, 340-363.

Milne, M., Tregidga, H., \& Walton, S. (2009). Words not actions! The ideological role of sustainable development reporting. Accounting, Auditing and Accountability Journal, 22 (8), 1211-1257.

Neuendorf (2002). The content analysis guidebook. Thousand Oaks, CA: SAGE publications.

Orlitzky, M., Siegel, D., \& Waldman, D. (2011). Strategic corporate social responsibility and environmental sustainability. Business \& Society, 50(1), 6-27.

PPPCouncil. (2015). The Canadian Council for public-private partnerships: Definitions. Retrieved August 2016 from: http://www.pppcouncil.ca/resources/about-ppp/definitions.html

Roca, L.C \& Searcy, C. (2012). An analysis of indicators disclosed in corporate sustainability reports. Journal of Cleaner Production, 20 (1), 103-118.

Rogers, M. M. and Weber, W. L. (2011) Evaluating CO2 emissions and fatalities tradeoffs in truck transport. International Journal of Physical Distribution and Logistics Management, 41(8), pp. 750-767.

Savelson,A. and Buckle,S.(2010). Sustainability Planning: Frameworks, Principals and Management Tools, Edmonton, Canada.

Scott, W. R. (1987). The adolescence of institutional theory. Administrative Science Quarterly, $32,493-511$.

Segal, D. L., Coolidge, F. L., O'Riley, A., \& Heinz, B. A. (2006). Structured and semi-structured interviews. In M. Hersen (Ed.), Clinician's Handbook of Adult Behavioral Assessment, 121145. London: Elsevier Acadmiec Press.

Sergiovanni, T. J. and Corbally, J. E. (1986) Leadership and Organizational Culture: New Perspectives on Administrative Theory and Practice, University of Illinois Press. 
Slaper, T. F. and Hall, T. J. (2011) The triple bottom line: What is it and how does it work? Indiana Business Review, 4-8.

Statistics Canada, 2016. Canada's population estimates. Retrieved January 2016 from: http://www.statcan.gc.ca/daily-quotidien/110622/dq110622a-eng.htm

St John, W. and Johnson, W. (2000) The pros and cons of data analysis software for qualitative research. Journal of Nursing Scholarship, 32(4), 393-7.

Suchman, M. C. (1995). Managing Legitimacy: Strategic and institutional approaches. Academy of Management Journal, 20 (3), 571 -610.

Tort, I.E. (2010), GRI Reporting in government agencies. Global Reporting Initiative Amsterdam. The Netherlands.

Unerman, J. (2000), Methodological issues: Reflections on quantification in corporate social reporting content analysis. Accounting, Auditing \& Accountability Journal, 13 (5), 667-680.

UN (2015), "Transforming our world: The 2030 Agenda for Sustainable Development", United Nations, New York, https://sustainabledevelopment-unorg.ezproxy.lib.ryerson.ca/content/documents/21252030\%20Agenda $\% 20$ for $\% 20$ Sustainabl e\%20 Development\%20web.pdf.

UNGC (2015). The United Nations Global Compact: ten principles, UN Global Compact Office, New York. Retrieved November 2016 from: https://www.unglobalcompact.org

Van der Esch, S. \& N. Steurer. (2014). Comparing developments in public and private sustainability monitoring and reporting. Scoping paper at the request of the Netherlands Ministry of Foreign Affairs, PBL report.

Van Marrewijk, M. (2003). Concepts and definitions of CSR and corporate sustainability: Between agency and communion. Journal of Business Ethics, 44 (2), 95-105.

Van Wenson, K., Broer, W., Klein, J., \& Knopf, J. (2011) The state of play in sustainability reporting in the European Union, 173.

Vigneau, L., Humphreys, M., \& Moon, J. (2015). How do firms comply with international sustainability standards? Processes and consequences of adopting the Global Reporting Initiative. Journal of Business Ethic, 131, 469-486

World Commission on Environment and Development (Chair Brundtland, G. H.), (1987). Our Common Future. Oxford: Oxford University Press, Oxford. 
White, G. B. (2009). Sustainability Reporting: Managing for Wealth and Corporate Health. New York: Business Expert Press.

Williams, B., Wilmshurst, T., \& Clift, R. (2011). Sustainability reporting by local government in Australia: Current and future prospects. Accounting Forum, 35(3), 176-186.

Willis, A. (2003). The role of the Global Reporting Initiative's sustainability reporting guidelines in the social screening of investments. Journal of Business Ethics, 43(3), 233-237.

Yin, R.K., (2009). Case Study Research: Design and Methods, fourth ed. SAGE Publications, Thousand Oaks, California, USA. 